THE EFFECT OF IN-ROW SPACING AND

SEEDTYPE ON THE YIELD AND QUALITY

OF A POTATO CULTIVAR

\author{
A Thes is \\ Submitted to the Faculty \\ of \\ Graduate Studies \\ The University of Manitoba \\ by \\ Martin Hermann Entz
}

In Partial Fulfillment of the

Requirements for the Degree

of

Master of Science

Department of Plant Science

October 1981 


\section{THE EFFECT OF IN-ROW SPACING AND \\ SEEDTYPE ON THE YIELD AND QUALITY \\ OF A POTATO CULTIVAR}

BY

MARTIN HERMANN ENTZ

A thesis submitted to the Faculty of Graduate Studies of

the University of Manitoba in partial fulfillment of the requirements

of the degree of

MASTER OF SCIENCE

() 1981

Permission has been granted to the LIBRARY OF THE UNIVER-

SITY OF MANITOBA to lend or sell copies of this thesis, to the NATIONAL LIBRARY OF CANADA to microfilm this thesis and to lend or sell copies of the film, and UNIVERSITY MICROFILMS to publish an abstract of this thesis.

The author reserves other publication rights, and neither the thesis nor extensive extracts from it may be printed or otherwise reproduced without the author's written permission. 


\section{ACKNOWLEDGEMENTS}

The author wishes to express sincere thanks to the following individuals and organizations for assistance given during this study.

My advisor, Dr. Lucien J. LaCroix, for his support, guidance and encouragement given freely throughout this project.

Professor J.A. Menzies, Department of Plant Science and Dr. S.Y. Reitsma, Department of Agricultural Engineering, for advice and interest shown in this project, as well as for reviewing this manuscript.

Lorne Adam and Doug Waterer for the many days they assisted in field work.

The University of Manitoba and the Natural Sciences and Engineering Research Council of Canada for financial assistance provided during this study.

My family for their support, encouragement and understanding. My friends, both on and off campus, for their encouragement good work boys! 
TABLE OF CONTENTS

PAGE

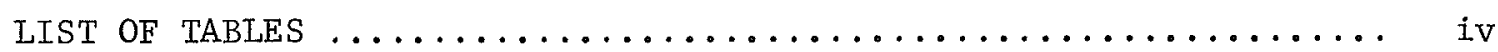

LIST OF FIGURES $\ldots \ldots \ldots \ldots \ldots \ldots \ldots \ldots \ldots \ldots \ldots \ldots \ldots \ldots \ldots \ldots \ldots \ldots \ldots \ldots \ldots$

ABSTRACT $\ldots \ldots \ldots \ldots \ldots \ldots \ldots \ldots \ldots \ldots \ldots \ldots \ldots \ldots \ldots \ldots \ldots \ldots \ldots \ldots \ldots \ldots \ldots \ldots$

INTRODUCTION $\ldots \ldots \ldots \ldots \ldots \ldots \ldots \ldots \ldots \ldots \ldots \ldots \ldots \ldots \ldots \ldots \ldots \ldots \ldots \ldots \ldots$

LITERATURE REVIEW $\ldots \ldots \ldots \ldots \ldots \ldots \ldots \ldots \ldots \ldots \ldots \ldots \ldots \ldots \ldots \ldots \ldots \ldots \ldots$

Potato Planters and Seedpiece Placement ............... 3

Effect of Irregular In-Row Spacing on Yield .............. 6

Seedtype and Seedpiece Size ......................... 8

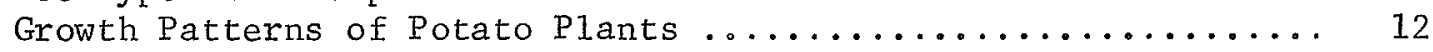

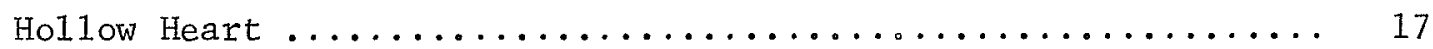

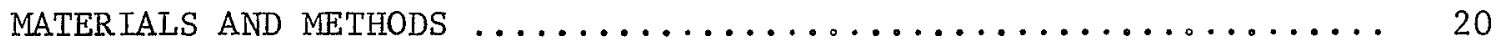

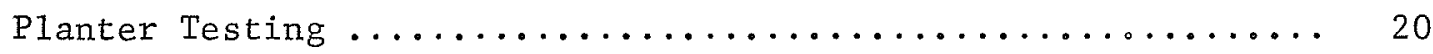

General Procedures $\ldots \ldots \ldots \ldots \ldots \ldots \ldots \ldots \ldots \ldots \ldots \ldots \ldots . \ldots \ldots$

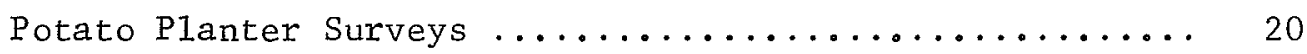

Field Experiments $\ldots \ldots \ldots \ldots \ldots \ldots \ldots \ldots \ldots \ldots \ldots \ldots \ldots \ldots \ldots \ldots \ldots$

General Procedures $\ldots \ldots \ldots \ldots \ldots \ldots \ldots \ldots \ldots \ldots \ldots \ldots \ldots \ldots \ldots$

Seedtype and In-Row Variation in Spacing Experiment

(cv Netted Gem); 1979, 1980 .................. 23

Seedtype and In-Row Spacing Experiment (cv Netted Gem);

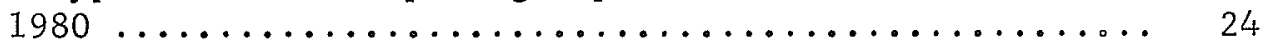

RESULTS AND DISCUSSION $\ldots \ldots \ldots \ldots \ldots \ldots \ldots \ldots \ldots \ldots \ldots \ldots \ldots \ldots \ldots \ldots \ldots \ldots \ldots$

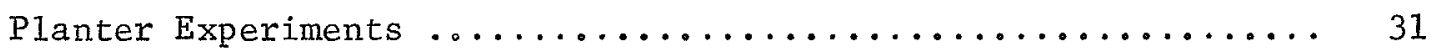

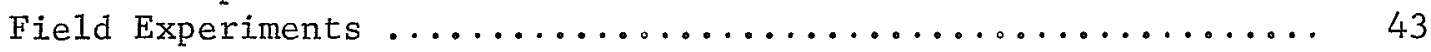

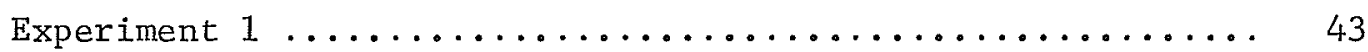

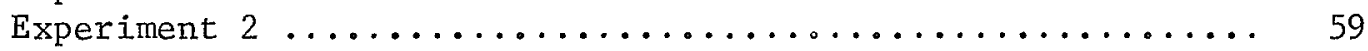

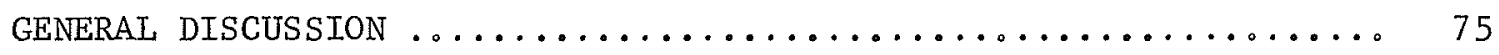




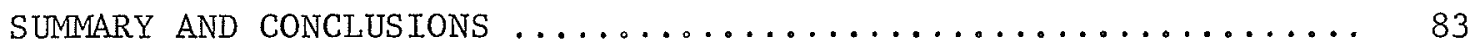

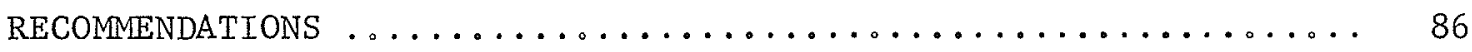

REFERENCES $\ldots \ldots \ldots \ldots \ldots \ldots \ldots \ldots \ldots \ldots \ldots \ldots \ldots \ldots \ldots \ldots \ldots \ldots \ldots \ldots \ldots \ldots$

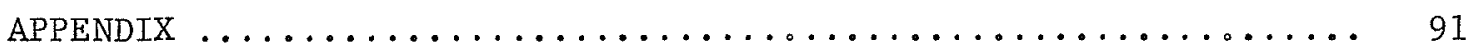


LIST OF TABLES

TABLE

PAGE

1 Effect of seedtype on production (number per plot) and yield ( $\mathrm{kg}$ per $\mathrm{plot}$ ) of tubers in the marketable and

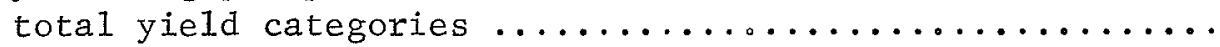

2 Effects of seedtype and in-row variation in spacing on production (number per plot) and yield ( $\mathrm{kg}$ per plot) of tubers in the unmarketable grade $\ldots \ldots \ldots \ldots \ldots \ldots \ldots$

3 Effect of in-row variation in spacing on production (number per plot) and yield (kg per plot) of tubers in the marketable and total yield categories .............

4 Effects of seedtype and in-row variation in spacing on production (number per plot) and yield (kg per plot) of tubers in the over-size grade $\ldots \ldots \ldots \ldots \ldots \ldots \ldots \ldots \ldots$

5 Effects of seedtype and in-row variation in spacing on production (number per plot) and yield ( $\mathrm{kg}$ per plot) of tubers in the mid-size grade $\ldots . \ldots \ldots \ldots \ldots \ldots \ldots \ldots \ldots$

6 Effects of seedtype and in-row variation in spacing on

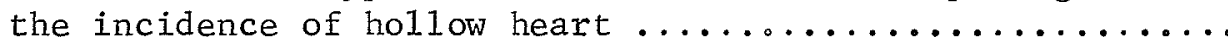

7 Effects of seedtype and in-row spacing on production (number per plot) and yield (kg per plot) of tubers in the marketable and total yield categories: Portage la Prairie, 1980 ................................

8 Effects of seedtype and in-row spacing on production (number per plot) and yield ( $\mathrm{kg}$ per plot) of tubers in the unmarketable, mid-size and over-size grades: Portage

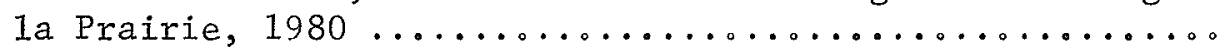

9 The mean mass, mean number of mainstems and mean mass per mainstem for three seedtypes: Portage la Prairie, 1980

10 The mean mainstem density for three seedtypes and three

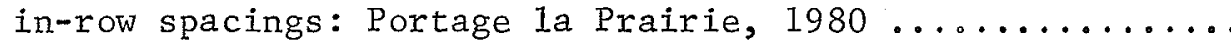

11 Mean number and mass (kg) of tubers per mainstem for three in-row spacings and three seedtypes: Portage la Prairie, 1980 
TABLE

PAGE

12 Mean number of branches per plant for three in-row spacings and three seedtypes: Portage la Prairie, 1980

13 Mean number of branches per mainstem for three in-row spacings and three seedtypes: Portage la Prairie, $1980 \ldots \ldots 72$

14 Mean percent ho11ow heart for three seedtypes and three in-row spacings: Portage la Prairie, $1980 \ldots \ldots \ldots \ldots \ldots . \ldots 73$

15 Meteorologica1 information: $1979 \ldots \ldots \ldots \ldots \ldots \ldots \ldots \ldots \ldots$

16 Meteorological information: $1980 \ldots \ldots \ldots \ldots \ldots \ldots \ldots$

17 Planting dates, fertilizer application rates and harvest dates for all locations in 1979 and $1980 \ldots \ldots \ldots \ldots . \ldots 9$

18 Highlights of the analysis of variance table showing the

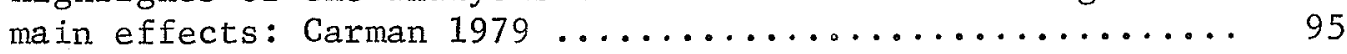

19 Highlights of the analysis of variance table showing the

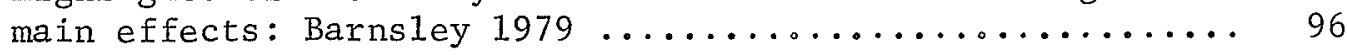

20 Highlights of the analysis of variance table showing the main effects: Portage la Prairie 1980 (experiment 1) ..... 97

21 Highlights of the analysis of variance table showing the

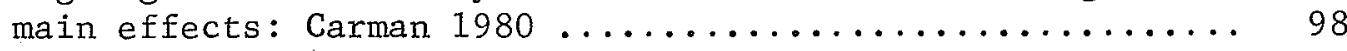

22 Highlights of the analysis of variance table for hollow

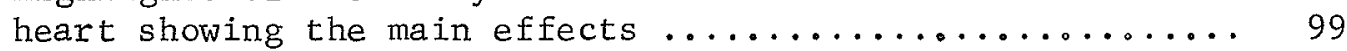

23a Highlights of the analysis of variance table showing the main effects: Portage la Prairie 1980 (experiment 2) ..... 100

23b Highlights of the analysis of variance table showing the main effects: Portage 1a Prairie 1980 (experiment 2) ..... 101 


\section{LIST OF FIGURES}

FIGURE

PAGE

1 Frequency distributions of seedpiece mass for three seedtypes ( $a$ : whole, $b$ : cut-graded, $c$ : cut-ungraded)

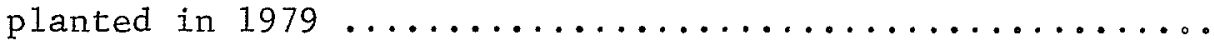

2 Frequency distributions of seedpiece mass for three seedtypes ( $\mathrm{a}$ : whole, b: cut-graded, $\mathrm{c}$ : cut-ungraded) planted

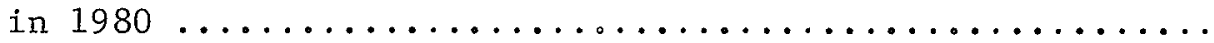

3 Frequency distributions of seedpiece mass for three seed types (a: cut-ungraded, b: cut-graded, c: whole) planted with a Lockwood potato planter (Model No.

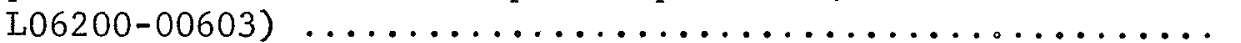

4 Seedpiece frequency distributions of in-row spacing distance for four potato planters $(a, b, c$, d) ......... 33

5 Seedpiece frequency distributions of in-row spacing distance for four potato planters $(a, b, c$, d) .........

6 Seedpiece frequency distributions of in-row spacing distance for three seedtypes ( $a$ : whole, b: cut-graded, c: cut-ungraded) using a Lockwood potato planter

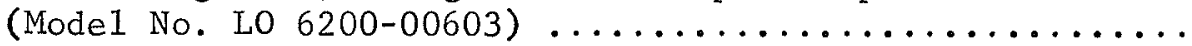

7 Effect of seedtype on tuber production (number per plot)

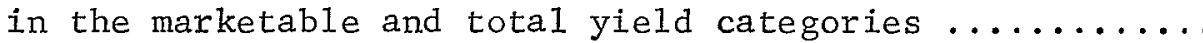

8 Effect of seedtype on the marketable and total yield

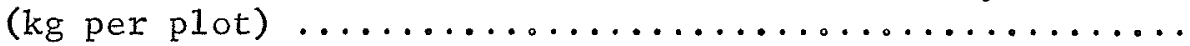

9 Effect of in-row variations in spacing on tuber production (number per plot) in the marketable and total yield

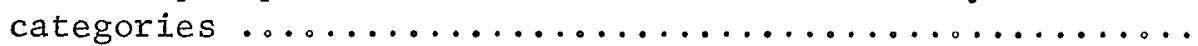

10 Effect of in-row variations in spacing on the marketable and total yield ( $\mathrm{kg}$ per plot) ................. 52

11 Effects of seedtype and in-row spacing on the tuber production (number per plot) and yield ( $\mathrm{kg}$ per plot) in the marketable and total yield categories ..............

12 Mean mainstem and branch number per plant for three inrow spacings and three seedtypes: Portage la Prairie, 1980 


\section{ABSTRACT}

Entz, Martin, H. M.Sc., The University of Manitoba, October 1981. The Effect of In-Row Spacing and Seedtype on the Yield and Quality of a Potato Cultivar. Major Professor; Dr. L.J. LaCroix

A survey was conducted in 1979 to determine the accuracy of in-row spacing of five models of potato planters. Irregular seedpiece spacing expressed in terms of coefficient of variation (CV), was observed for al1 planters tested. The CV levels recorded in the survey ranged from $50.1 \%$ to $76.5 \%$. The use of seedpieces of uniform size was effective in improving the accuracy of placement of a Lockwood "Accumatic" planter.

The effect of irregular spacing on tuber production number and yield was tested at two locations in both 1979 and 1980. Irregular spacing resulted in reductions in total and marketable yields in 1980, however, no effect was observed in 1979. At one location in 1980, yield decreases were measured for each increase in irregularity of spacing $(\mathrm{CV}=0,25$, 50 and 75), however, differences were not significant $(P=.05)$. At the same location, total tuber production was significantly lower at the highest level of irregular spacing tested.

No significant interaction was found between irregular spacing and three seedtypes (whole seed, cut hand-graded seed and cut ungraded seed). In addition, no significant interaction was found between three accurate spacings $(30.4,45.7$ and $60.9 \mathrm{~cm}$ ) and the same seedtypes. No difference in yield was found between crops grown from different seedtypes at the closest spacing, while the crop grown from large seedpieces was superior, in terms of marketable and total yield, at the widest spacing. 
Counting of mainstem and branch numbers was conducted to determine the extent to which potato plants can adapt to variations in spatial arrangements within the row. The number of mainstems per plant was affected by the seedpiece size, with larger seedpieces producing more mainstems. The number of basal branches per plant increased with increased spacing. Plants grown from whole seedpieces most effectively compensated for in-row gaps, as the number of branches per plant increased significantly $(P=.05)$ in a linear relationship with increased spacing.

The incidence of hollow heart differed greatly between years and spacings. Increased plant stresses appeared to cause higher incidence of this disorder. 
INTRODUCTION

The mechanical deficiencies of potato planters have been recognized as a contributing factor to irregular plant stands (Andrew et al., 1968; Jarvis et a1., 1976; Misener, 1979). Additional factors such as deep planting and diseased seedpieces can also contribute to gaps within the row (Ohms and Cross, 1967; James et al., 1973).

Spacing has been found to be more irregular with fully automated planters than with hand-fed planters (Pascal et al., 1977). Fully automated planters are now almost exclusively used by growers in Manitoba.

From studies conducted in Great Britain, it was shown that yield reductions can occur with irregularly spaced plants (Jarvis and Palmer, 1973), In addition, it was found that environmental factors can modify the effect of irregular spacing on yield (Jarvis et al., 1976). For these reasons, studies on the effect of irregular spacing may not apply to conditions in Manitoba.

The objectives of this study were: (1) to determine the accuracy of potato planters used in Manitoba, and (2) to determine the effect of irregular spacing and seedpiece type on yield and quality of the crop. In addition, experiments were designed to test the interaction between different seedpiece types and irregular spacing. Such experiments are more appropriate to North American potato production, as there is widespread use of cut seedpieces, whereas previous studieswere conducted with whole seedpieces.

There have been several reports which indicated little effect of 
irregular spacing on yield. A second field experiment was conducted in which mainstem and branch numbers were counted in an attempt to determine how potato plants can adapt to differences in their in-row arrangements. 


\section{LITERATURE REVIEW}

\section{Potato Planters and Seedpiece Placement}

Many observations have been made of irregular plant stands in commercial potato fields. It has been suggested that the gaps within the row are due to many factors including deep planting, diseased seedpieces and poor drainage (James et al. 1975). Ohms and Cross (1967) stated that in Idaho loss in stand is primarily due to seedpiece decay resulting from lack of suberization of the cut surface of the seedpiece. While all of these factors can cause missing plants, only the mechanical deficiencies of potato planters can result in doubles or seedpieces being clustered within a row. Irregular seedpiece placement due to sub-optimal performance of potato planters has been reported in both North America and Europe.

Many field surveys have been conducted to investigate the actual planter performances and to determine causes of irregular plant stands. James et a1. (1973) found that $88 \%$ of misses in potato fields were due to absence of seedpieces and $7 \%$ of misses due to rolling of the seedpiece to a position next to an adjacent unit, thus causing a miss. Less than $4 \%$ of misses were due to rotten seedpieces, fungal diseases (Fusarium spp. and Rhizoctonia spp.) and blind seedpieces. In a field survey by James et al. (1973) it was found that $23.2 \%$ and $24.2 \%$ of plants were missing in tablestock and seed fields, respectively. Jarvis et al. (1976) found the gaps between the plants to be distributed in a typical 
normal distribution and irregularity could, therefore, be defined in terms of the standard deviation of the mean. Measurements made on crops planted with the same type of planter but at different mean spacings suggested that the standard deviation of the distribution of seedpiece spacings varied with the mean. For this reason they decided that the coefficient of variation (CV) would be a better indication of potato planter accuracy. $\mathrm{CV}$ has become increasingly popular as a measure of planter performance in field surveys.

Misener (1979) found the CV to range from $55.3 \%$ to $87.1 \%$ for eight different planters. Pick-type planters and cup-type planters had CVs of 55.3 to $68.7 \%$ and 59.2 to $87.1 \%$, respectively. A considerable number of doubles were recorded for both planters.

This work is supported by a field survey conducted in two areas of Alberta where it was found that potato stands had CVs ranging from 50 to $88 \%$ (Andrew et al., 1968). On the basis of detailed investigations in 1968, they concluded that the mechanical deficiencies of potato planters were the major causes of missing plants, and not seedpiece decay as reported by Ohms and Cross (1967) in Idaho. However, it should be noted that seedpiece decay can be a major factor when cut seed has not been suberized.

Many studies have been conducted in Europe to determine the accuracy of automated potato planters. Special emphasis has been in comparing the more recent fully automated planters, with the labour intensive hand-fed planters. In comparing the two types, Pascal et al. (1977) found hand-fed cup planters to be superior to the automated planters with CVs of 18.5 to $23 \%$ and 60 to $65 \%$, respectively. Similar values were found by Jarvis and Palmer (1973). They recorded 15 to $20 \%$ CV for 
hand-fed planters and 45 to $55 \% \mathrm{CV}$ for the more recently introduced belt-fed machine.

In contrast to these findings, Shotton (1976) claimed that handfed planters do not always perform as well as observed by the two previous authors. He found that under field conditions, CVs of hand-fed planters could be between 30 and $40 \%$. There was, however, agreement between Jarvis and Palmer (1973), Shotton (1976) and Pasca1 et al. (1977) on the accuracy of the fully automated planters. Jarvis et a1. (1976) recorded similar CV values for an automated cup-fed planter. The accuracy of potato planters, while affected by the type of planter and care in adjustment and maintenance, is also affected by the seedpieces it plants. More efficient planting was reported by Palmer (1976) and Shotton (1976), when the seed used was round and relatively uniform in size. This was supported by work done by Pascal et al. (1977). In comparing the two cultivars Redskin (a flat round cultivar) and Arron Pilot (a long oval cultivar), an apparent slight reduction in the CV (not significant at $\mathrm{P}=0.05$ ) was obtained with closely graded seed. However, higher overall CVs were obtained when planting Arran Pilot tubers. They also observed that irregular shaped tubers caused the feeding mechanism on the planter to work poorly.

Misener (1979) found that as in-row spacing increased, the incidence of doubles and misses was reduced with an $R$ value of 0.97 and 0.94 , respectively. He also observed fewer doubles when pick-type planters were operated at lower speeds $(5.6$ to $7.2 \mathrm{~km} / \mathrm{hr})$, whereas no clear pattern was observed with cup-type planters regarding forward speed. Pascal et a1. (1977) concluded that the forward speed of European planters had no apparent effect on regularity of tuber spacing. 


\section{Effect of Irregular In-Row Spacing on Yield}

"Changing the space between plants, which may also

mean the density of the stand and, therefore, the inter-plant competition, influences the developmental rhythm of the stand and also the final yie1d." (Svensson, 1972)

While there have been many experiments conducted to establish the optimum plant density for individual potato cultivars in various growing regimes, less work has been done to establish the effect of irregular plant density on final yield and size distribution of the crop (grade). Many attempts have been made to find the effects of a poor stand on yield and grade, however, some are less useful because the treatments do not reflect actual spacing patterns displayed by potato planters.

Hirst et a1. (1973) used a technique which involved removing plants from the row at emergence to produce a poor stand. By removing 4, 8, 12, 16 and $24 \%$ of the plants, corresponding yield decreases were 1,3 , 4, 8 and 9\%, respectively. James et al. (1973) carried out a similar study involving removal of $0,10,20$ and $30 \%$ of plants randomly in the row. There were significant yield decreases in all three test cultivars (Kennebec, Netted Gem and Katahdin) with $30 \%$ of the plants missing in 1970, whereas only Netted Gem yielded significantly less with such a stand, in 1971 (Overall yields were less in 1971).

The above experiments are useful, but do not reflect actual planter performance. There have been several workers who have designed experiments where the treatments reflect actual stands in commercial potato fields. Schepers (1975) conducted an experiment in which he used four treatments (A - regular spacing, $22 \mathrm{~cm}$; B - sequence of $44-14-8 \mathrm{~cm}$; 
C - sequence of $66-18-12-8-6 \mathrm{~cm}$; and D - sequence of $88-22-$ $16-12-8-4-4 \mathrm{~cm})$. The mean spacing did not differ between treatments making this experiment more valid than those involving the removal of plants. Schepers found that total yield as well as seed yield (28 $45 \mathrm{~mm})$ decreased by 14 to $17 \%$ and 8 to $11 \%$, respectively, when harvested immaturely. At mature harvest, yields were not significantly affected by any strong deviations from regular plant spacings. This is supported by Pascal et a1. (1977). At individual sites they found that regular spacing (based on a hand-fed machine) tended to outyield irregular spacing (based on an automated belt planter), but no differences were significant.

In a similar experiment (Jarvis et al., 1976) it was found that although differences in total and marketable yields $(>44 \mathrm{~mm}$ ) resulting from a range of CVs (0 to 60\%) were small and usually not statistically significant, certain trends were evident. For one of the cultivars tested (King Edward), both total and marketable yields decreased with each increment in CV. The other test cultivar (Pentland Crown) showed the same trend except at one site where total and marketable yield decreased up to a $\mathrm{CV}$ of $40 \%$ and then increased when the $\mathrm{CV}$ was equal to $60 \%$. This suggests that the response to irregular spacing may be partially dependent on the cultivar planted and the environmental conditions. Evidence of reduced total and marketable yield was shown by several other authors as well. Jarvis and Palmer (1973) found that the marketable yield decreased by $1.6-1.8 \mathrm{t} /$ ha for a CV of $50 \%$ as compared to one of 20\%. In Scheper's (1975) experiment it was observed that irregular planting leads to stem competition, reduced stem numbers and a wider distribution of tuber sizes at harvest. 
This observation was supported by Jarvis et al. (1976) who found that although total yield was not reduced significantly by irregular spacing, a wider distribution of tuber sizes occurred. When the harvested tubers were graded into three categories ( 1 - 44 to $57 \mathrm{~mm}$; 2 57 to $70 \mathrm{~mm} ; 3-70$ to $83 \mathrm{~mm}$ ), there was a decrease in the yield of sizes one and two and an increase in the yield of size category three, with the high CV. Depending on the particular market for which the potatoes were grown, a fluctuation in the yield in any one category due to irregular spacing, would reduce the marketable yield. Similar results by Pascal et al. (1977) showed yield of tubers in the mid-size grade to be greater, relative to other grades, when seedpieces were regularly spaced. However, James et al. (1973) found no differences, with regard to size distribution, between treatments containing no missing plants and treatments with missing plants.

Jarvis et al. (1976) concluded that there was an interaction between plant populations and irregular spacing. Effects of irregularity on marketable yield were appreciably more marked at Iow populations. Such observations had also been made earlier by Davies (1954), who noticed reduced yields only at wide mean spacings of $55.9 \mathrm{~cm}$ and $76.2 \mathrm{~cm}$.

\section{Seedtype and Seedpiece Size}

Much work has been done to establish the optimum seedpiece weight for optimum total and marketable tuber yield. In an experiment using seed $^{1}$ weights of $14.2,28.4,42.5$ and $56.7 \mathrm{~g}$ cut and $56.7 \mathrm{~g}$ whole seed, Iritani et al. (1972) found that the differences in seed size resulted

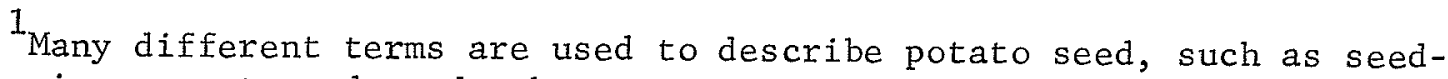
pieces, sets and seed tubers.
} 
in significant differences in total yield. Cut and whole seed (56.7 g) resulted in the highest average stem number and the highest yield of marketable tubers (greater than $5.08 \mathrm{~cm}$ in diameter). The yield advantage of larger seed (cut or whole) has also been reported by Painter et a1. (1970) and Jarvis and Shotton (1971).

Taha (1961) stated that the difference in yield between plants grown from large and small seed are relatively smaller than the differences in seed size; small seedpieces appear to be more efficient. He also found that dry matter production of plants from large and small seedpieces converges (completely in a good season and incompletely in a dry season), and is largely established in the early part of the season. Converging growth patterns were also found by Scott and Younger (1972). They reported the yield advantage which large seedpieces provide early in the season diminishes with time as the inter-plant competition develops. This is supported by Black (1957) who stated that after establishment, seed size has no direct effect on the relative growth rate and the behaviour of plants from large and small seed depends upon. the intensity of the inter-plant competition to which they are subjected. He found that if the competition was low (as with wide spacing) the initial advantage of plants from large seed may be maintained for a longer period. Black (1957) and El Saeed (1963) both reported that in a mixed population of large and small seed, the greater initial size of plants grown from large seedpieces gives them a competitive advantage. However, they found that although the differences increased with time, the dry matter production in the mixed population as a whole, may not differ significantly.

In looking for a reason for the possible higher efficiency of 
small seed, El Saeed (1963) found that the yield difference between large and small seed tubers appears to arise from a difference in the duration, rather than the rate of bulking, unless the plants from small seed produce fewer tubers. This is due to his observation that plants from large seedpieces have earlier tuber initiation. Mush (1962) also investigated the relative efficiencies of large and small seedpieces. He reported that the presence of seed tubers has a marked suppressing effect on photosynthesis. He attributed the effect to the supply of a large amount of carbohydrates to the leaves in plants from large seed tubers. He concluded that it is possible that the comparative scarcity of reserve materials in small seed is to some extent compensated for by less suppression of photosynthesis.

Reestman and Dewit (1959) concluded that with the cultivar Alpha, the current opinion that small seed is inferior to large seed is incorrect. They reported that with a large seedpiece, a large number of stems develop from one potato and a yield depression due to the irregular distribution of stems in the row results. Similar results were found by Scott and Younger (1972) who reported that at the same weight of seed per acre, small seed is clearly more efficient in producing mainstems, tubers and total yield. This is supported by Boyd and Lesse11s (1954) who related yield with total weight of planted seed and not with plant numbers. They found that the yield effect of $1 \mathrm{~kg}$ of seed tubers is greatest for the sma11 seed $(25-28 \mathrm{~mm})$ than for the large seed $(45-60 \mathrm{~mm})$.

Different seedpiece sizes have been found to result in plants with differing characteristics. Svensson and Naglicka (1975) found that large seed tubers have a greater number of sprouts and correspondingly 
greater stem number. They also observed that large seed tubers have fewer sprouts per unit weight of tuber, hence greater initial vigour. Taha (1961) found that tuber yield is almost invariably greater from large than small seed at the same population. Plants from large seedpieces often produce more tubers than plants grown from small seedpieces (Scott and Younger, 1972). Harris (1978) reported that this may result in an increase in the yield of sma11, unmarketable tubers. Environmental conditions have been found to be an additional factor in tuber yield. Both Svensson (1973) and Storey and Barry (1976) reported increased tuber set with favourable moisture conditions at tuberization. Curves for increase in yield with increase in seedpiece size have been shown to be asymptotic (Roer, 1955). Roer also observed that cultivars, with inherently high stem numbers, are much less responsive to increases in seed size than those with inherently low stem number. Svensson and Naglicka (1975) reported that plants from small seedpieces have fewer stems per plant and thus less inter-plant and intra-plant competition. They also observed that the relative growth rates of stems from small seedpieces does not fall as quickly as that of stems from large seedpieces. These observations, in addition to those mentioned earlier, serve as good support to the observations by Taha (1961) that the difference in plant size and dry matter production between plants from small and large seedpieces, is relatively smaller than the difference in seedpiece size.

As was mentioned earlier, in the work of Iritani et al. (1972), there did not appear to be yield advantage in using whole seed. There have been many other reports which also show no significant yield differences between whole seed and cut seed (at similar weights) 
(Sadler, 1961; Iritani, 1968).

However, whole and cut seed may produce different growth patterns of potato plants. Iritani (1968) found that plants from cut seedpieces emerged considerably faster than from whole seedpieces, but also observed that plants from whole seedpieces were more vigorous. Sadler (1961) found that cutting seed tubers generally stimulated the formation of more stems. Iritani (1968) found no difference in stem number, but suggested this could be because the tubers which he used had just broken dormancy. In most species, the apical bud exerts an inhibitory influence (apical dominance) upon the lateral buds, preventing their development (Salisbury and Ross, 1978). Iritani (1978) reported that the cutting of seed tubers disrupts the apical dominance and affects the growth patterns. Emilsson (1949) also found that the degree of apical dominance displayed by a whole tuber will affect its growth pattern.

\section{Growth Patterns of Potato Plants}

"As commercial crops of potatoes are vegetatively propagated from sets with more than one growing point; the primal plant unit is more difficult to define than in other crops grown from seeds, each with only a single embryo." (Bleasdale, 1965)

Iritani et al. (1972) found that yields increased with larger seed, and within each spacing the yield was directly related to the average stem number per plot. They concluded that higher yields were obtained with the greater weight of seedpiecesper stem $(R=+0.982)$. Lynch and Rowberry (1977) found that as the stem number per unit area increased, total yield per stem decreased. Taha (1961) reported evidence of an 
inverse relationship between stem number per plant and tuber number per stem, and suggested that this may partially frustrate attempts to increase seed yield by increasing stem number per unit area.

In a given seedlot, closer planting does not restrict the increase in mainstem number as the season advances (Bates, 1935). Bleasdale (1965) reported that density of seedpieces has only a small effect on mainstem number per plant. This is supported by Svensson (1973) who found the number of mainstems per hill was the same for all spacings with a $70 \mathrm{~cm}$ row spacing. In his experiment, the standard deviation in mean number of mainstems in the crop did not vary during the sampling period, and therefore, no change in population occurred. Lynch and Rowberry (1977) found that the number of stems per hill was not influenced by rate of fertilizer application or plant density in two successive years. Taha (1961) did not find any effect of density on stem number per hill except in cultivars with inherently high stem numbers.

Lynch and Rowberry (1977) observed increased branch development at wider spacings and high rates of fertilization, in both years of their experiment. They concluded that the relationship between axillary branch development and plant density ensured a similar leaf area index over a range of densities studied, and suggested that this possibly accounts for the lack of yield response with increased plant density. They also reported that although seed size was precisely controlled in both seasons, stem density was $65 \%$ greater in the second year of testing. This again helps to explain the difficulty in achieving a predictable population density.

Another factor in establishing a given stem density is the condition 
of the seedpiece itself. Iritani (1968) suggested that the control of physiological age of the seedpiece, and thus the number of stems per seedpiece, would be of considerable importance in the production of potatoes. He based this on the results of his experiments which showed that the longer seed was stored, the shorter the period for emergence and the greater the stem number. Bogucki and Nelson (1980) did similar work but expressed age of the seedpiece in terms of its degree of dormancy.

Toosey (1963) stated that the physiological age of seed tubers is influenced by: Environmental conditions during growth (particularly high temperatures during latter part of season), harvesting while immature, high storage temperatures and pre-sprouting of seed tubers before planting. Wright and Peacock (1934) found that, in general, the higher the storage temperature over a range of about $4-21^{\circ} \mathrm{C}$, the shorter the residual dormant period of both American and British cultivars. This was supported by Schipper (1956) who found that raising the storage temperature shortened the residual dormant period by $18 \%$. Iritani (1968) reported that dormancy appeared to be associated with apical dominance (slower emerging plants have fewer stems).

Due to the importance of stem number and distribution, and their relationship with yield, there have been several reports on the relationship of both seed type and stem number with yield. Reestman and Dewit (1959) found that yield increased as the stem density increased. They suggested that this type of density measurement is not as clearly defined as plant or even seed weight, as the number of stems depended on seedpiece number, size of seedpiece, stage of dormancy and conditions at emergence. In response to this, they established a relationship 
between three seed tuber characteristics (average diameter, surface area of skin and volume of tubers) and the stems per seedpiece. At wide spacing the relationship was linear. They went one step further and plotted surface area of tubers planted against surface area of tubers harvested. The observations are, irrespective of size of set, reasonably well arranged around straight 1ines. Reestman and Dewit (1959) also observed that stems develop in groups of 5 - 10 from large seed and in groups of 1 - 3 from small seed. Also, they found that the space within the row occupied by plants growing from one unit of skin of small tubers planted wide apart was larger than the space occupied by plants growing from one unit of skin surface of large tubers, wide apart. They concluded that the stems from large seed cannot overcome the disadvantage of irregular distribution within the row, whereas stems from small seed adapt better. They demonstrated this by cutting large seed tubers and obtaining a higher yield when the smaller cut seed was planted. This supports work done by Boyd and Lessels (1954). Bleasdale (1965) was critical of this work as Reestman and Dewit did not establish the precise relationship between stem number, skin area and set weight. He showed that stem number is a function of the number of eyes. He plotted a linear relationship between the mean eye number per seedpiece and the mean sprout number per set using the cultivar Majestic. It should be noted that post-harvest treatments of the sets can affect the viability of eyes (Ivins and Milthorpe, 1963). Both Haughdal (1957) and Bremner and El Saeed (1963) reported that many stems growing in a clump did not result in yield reductions. However, Davies' (1954) results supported those of Reestman and Dewit (1959) when he observed that at low stem density, clumping can reduce yield. 
Despite various differences of opinion, it appears that stem number is a better indicator of yield than seedpiece weight (Bleasdale, 1965). However, in a given seedlot, it is possible to establish an improved relationship between seed type, weight, stem number and yield, if the physiological condition of the seed tuber is known (Iritani, 1968).

The importance of stem number as a measure of density has been demonstrated by several other workers as well. Lynch and Rowberry (1977) found tuber production (numbers) to be in a linear relation with mainstem number. In their experiment, the number of marketable tubers was unaffected by plant density, except for a decrease at the highest density. (Densities were 4.0, 4.9, 6.3, 8.2 and $11.1 \times 10^{4}$ plants/ha,) They observed, as Taha (1961) did, that there was a trend toward decreased tuber number per stem with increased plant density. Lynch and Rowberry (1977) found that as stem number $/ \mathrm{m}^{2}$ increased, marketable yield ( $>90 \mathrm{~g})$ per stem decreased. This is supported by Scott and Younger (1972). Scholte (1975) found that crop yield and grade is determined by the number of mainstem per unit area. In an experiment to establish an optimum density for yield of marketable table potatoes, he found that 12 - 13 mainstems $/ \mathrm{m}^{2}$ were optimum for marketable crops and total yield increases ceased at 30 mainstems $/ \mathrm{m}^{2}$. The value of stem number as a measure of density is given merit by Scholte's (1975) observation that the optimum density is higher for the cultivar Alpha than for the cultivar Bintje (Alpha having inherently fewer mainstems per seedpiece than Bintje). Roer (1955) found high densities to be superior in good as compared to poor seasons.

Jarvis et al. (1976) studied the effect of irregular seedpiece spacing on yield of potatoes. They established a relationship between 
seedpieces per hectare and yield of marketable potatoes, which resulted in a "quadratic-type" curve. It was found that if the mean population is close to that required for maximum yield in a given year, large variations in spacing had comparatively little effect on yield because of the "flat-topped" form of the response curve. Variation in spacing showed a greater effect on yield when the mean population was suboptimal. Many of the factors discussed earlier (seedtype, stem number and environmental conditions), may be important, as they could affect the seedpiece density-yield response curve.

\section{Ho11ow Heart}

Hollow heart is a hollow area or cavity formed within the tuber. It is classified as a physiological disorder because there are no causal organisms (Arteca, 1980). Hollow heart has been known to cause substantial losses to growers (Nelson et al., 1979).

There are several theories for the incidence of hollow heart in potato tubers. Crumbly et al. (1973) stated that hollow heart may initially be caused by subjecting the potato plant to stress after tuber initiation. Dinkel (1960) hypothesized that reabsorption of water, mineral nutrients and carbohydrates from small tubers by the growing tops causes injury to some tuber cells and the injured cells were incapable of rapid cell division and/or enlargement even after the stress was alleviated. Levitt (1942) reported that tubers under moisture stress converted stored starch to soluble sugars, resulting in a greatly reduced water potential in the tuber. When the water demand is again lower in the plant, water is translocated rapidly into the tuber. He suggested the result to be a rapid, though perhaps short, period of cell 
enlargement occurring primarily in the perimedullary region where the water potential would be the lowest. The growth differential between pith and perimedullary cell regions would cause a rupture. Some support can be found for this theory. Crumbly et al. (1973) reported that hydrolytic activities, particularly the hydrolysis of starch, increase with desiccation. Yamagucki et al. (1964) found the sugar content highest in tubers under stress of high soil temperatures $\left(27-29^{\circ} \mathrm{C}\right)$. Crumbly et $\underline{\text { al }}$. (1973) concluded that this type of stress (first water stress, then if prolonged, sugars converted from starch may be resorbed by other plant parts) can be found in the field. More recent evidence in this area has been provided by Arteca et al. (1980) who reported lower calcium levels in hollow heart tubers as compared to tubers without hollow heart. Also, a calcium gradient was found in hollow heart tubers, which resulted in higher concentrations at the stem end of the hollow tubers. They speculated that during moisture stress, plants draw upon tubers as a source of moisture, which causes relocalization of calcium. This appeared to account for the lower calcium levels and the calcium gradient observed in hollow heart tubers.

Another, more popular theory, is that hollow heart is induced by rapid tuber enlargement, and stress is not necessary for induction. This theory is supported by several workers. Moore and Wheeler (1928) reported 10 times more hollow heart in Russet Burbank potatoes during the months of August and September in irrigated plots, where rapid tuber growth occurred, than in potatoes from non-irrigated plots. Crumbly et a1. (1973) supported this in a greenhouse and field experiment. In the greenhouse (from April 27 to June 1) tubers with hollow heart increased an average of $5.3 \mathrm{~g}$ per day compared to 3.4 per day for non-hollow tubers. 
They found similar results in the field. Nelson et al. (1979) also found hollow heart to be more prevalent in large tubers. In 12 tuber lots $43 \%$ of the tubers over $8.89 \mathrm{~cm}$ were hollow compared to less than $1 \%$ of tubers under $5.08 \mathrm{~cm}$ in diameter.

An experiment was conducted to investigate the environmental conditions which promote hollow heart. Nelson et a1. (1979) found that four independently significant factors were degree days after tuber initiation ( -0.753$)$, days after tuber initiation (+0.699), plant population (-0.530) and rainfall after tuber initiation (+0.320). They concluded that in the cultivar Norgold Russet, hollow heart was lowest when plants were closely spaced, temperatures following tuber initiation were high and rainfall was low. These are also the conditions that would generally slow the rate of tuber enlargement (Nelson and Thoreson, 1974).

Nelson (1970) found the additive effects of early planting, close spacing and potassium reduced hollow heart from $45.9 \%$ to $5.7 \%$. Of these treatments, close spacing was found to give the most effective control. Observations made by Nelson over the period of this study indicated that hollow heart is particularly serious when plant stands are poor, moisture is adequate or heavy, temperatures are below normal and plants are vigorous. Other workers have also shown close spacing to reduce the incidence of hollow heart (Moore and Wheeler, 1928; Edmunds on, 1935). 
MATERIALS AND METHODS

\section{Planter Testing}

\section{Genera1 Procedures}

Field sampling was carried out to establish in-row spacing accuracy of potato planters. Sampling was done away from the headlands, in four areas diagonally across individual fields. Each area was $15.2 \mathrm{~m}$ in length while the width corresponded to that of the respective planter. In order to detect differences among individual planting mechanisms on a machine, each sampling area contained all rows corresponding to one pass by the planter. All of the rows were uncovered by hand and the distance between seedpieces was measured. Field sampling was conducted 1 to 3 weeks after planting.

The irregularity or variation of the in-row spacing was expressed in terms of its coefficient of variation (CV). As the CV values can be similar for distributions with different mean spacings, the measurements taken were estimates of the ability of potato planters to place seedpieces at equal distances.

Potato Planter Surveys. A survey of 12 grower fields and five planters was conducted in Manitoba in 1979. These fields ranged in size from 8 to 32 hectares. Seedtype, planter manufacturer and machine settings for seedpiece spacing were recorded. In one instance the ground speed of the planting operation was also recorded. After collecting data as previously described, statistical analyses were carried out to determine 
the planter accuracy in each field. Since several similar planters were tested, only the results from eight planters will be reported. Since the seedtype may strongly influence planter performance, a separate experiment was carried out using whole seed and cut seed (cv Netted Gem) and a Lockwood "Accumatic" planter. The whole seed had a mean mass of $95.6 \mathrm{~g} \pm$ a standard deviation of $21.0 \mathrm{~g}$. The first type of cut seed was hand-graded in order to obtain a seedlot relatively uniform in size. The mean mass of these seedpieces was $59.6 \mathrm{~g} \pm$ a standard deviation of $21.6 \mathrm{~g}$. The second type of cut seed was left ungraded and had a mean mass of $38.3 \mathrm{~g} \pm$ a standard deviation of $18.1 \mathrm{~g}$. In addition, mass distributions and the $\mathrm{CV}$ values for each distribution were recorded. They are presented in Figure 3.

Approximately one-fifth hectare was planted with each seedpiece type. The planting depth was $5 \mathrm{~cm}$ and the tractor speed was maintained at $8 \mathrm{~km}$ per hour. The planted areas were then sampled as previously described.

\section{Field Experiments}

\section{General Procedures}

Field experiments were conducted in Manitoba for two consecutive years. In 1979, experiments were carried out at Carman on an Almasippi very fine sandy loam, and at Barnsley on an Almasippi loamy fine sand. In 1980, experiments were again conducted in the Carman area, and on a Nuenberg loam soil at Portage la Prairie. The climatic data for these locations are presented in Tables 15 and 16 (Appendix). All field experiments were conducted within commercial potato fields. Fertilizer, herbicide, insecticide and fungicide applications, as well as spring and mid- 
season cultivations were done by the respective growers. All locations were treated with the herbicide Eptam, prior to planting. Applications of insecticides and fungicides were made according to the schedule used by the respective growers. No serious problems with pests of any kind were encountered in any of the experimental plots.

Immediately prior to planting, furrows were made in the plot area using a potato planter without covering discs. The distance between the rows varied with location, as it corresponded to that of the respective grower. A measuring tape was placed in the furrow and seedpieces were hand-planted at predetermined spacings. The certified seed used in all field experiments, was supplied by Toni Adrianson of Carberry, Manitoba. Two guard rows were planted along each side of the plot area. Guard rows were also established across the plot area by planting a single seedpiece at a distance of $45.7 \mathrm{~cm}$ from the first and last seedpiece in each row. The resulting plants were removed immediately prior to harvest. After planting, the rows were covered with soil using two discs which resembled the covering discs on a potato planter. Weeds that emerged prior to crop emergence were controlled with applications of paraquat. Seven to 10 days before harvest the plants were desiccated with one application of reglone. The crop was harvested with a one-row potato harvester.

The entire crop from each plot was graded into three categories on the basis of both tuber size and mass. As these potatoes (cv Netted Gem) are grown primarily for the processing market, all grading was done according to standards used by the processing industry. The first grade consisted of tubers which passed through a $5.08 \mathrm{~cm}$ grading chain and made up the unmarketable portion of the crop. The second grade consisted 
of tubers greater than $5.08 \mathrm{~cm}$ in diameter and less than $283.5 \mathrm{~g}$ in mass. Al1 tubers in the second category that appeared to be heavier than $283.4 \mathrm{~g}$ were weighed individually. Tubers which were heavier than $283.4 \mathrm{~g}$ constituted the third grade.

The tuber production and yield $(\mathrm{kg})$ were recorded for each of the three grades. Also, a sample of 24 tubers was taken from both the second and third grades. These tubers were later cut in half to allow detection of hollow heart. The data were analyzed statistically and Duncan's multiple range test was used as the test of significance.

Seedtype and In-Row Variation in Spacing Experiment (cv Netted Gem); 1979, 1980. This experiment was established in the field as a split-plot design replicated four times, with levels of $\mathrm{CV}$ as main plots and seedpiece types as subplots.

The coefficient of variation of seedpiece distribution has been used in the past (Jarvis et al., 1976; Pascal et al., 1977), to represent planting accuracy of potato planters. The CV levels used in this experiment were based on earlier planter surveys conducted by the Prairie Agricultural Machinery Institute, Portage la Prairie (P.A.M.I. Evaluation Report No. E1178A, 1978).

Individual rows (22.6 $\mathrm{m}$ in length) in the experiment represented individual plots. Fifty seedpieces were distributed in the $22.6 \mathrm{~m}$ plots at four levels of $\mathrm{CV} ; 0 \%, 25 \%, 50 \%$ and $75 \%$. A mean spacing of $45.7 \mathrm{~cm}$ was maintained for each level of $\mathrm{CV}$. Whole seed and two types of cut seed were planted. The whote seed had a mean mass of $75.2 \mathrm{~g}$ and $77.6 \mathrm{~g}$ in 1979 and 1980, respectively. The first type of cut ${ }^{1}$ sseed was hand-

$1_{\text {Seedcutting was done with a Milestone seedcutter by Toni Adrianson }}$ of Carberry, Manitoba. 
graded to eliminate small seedpieces and had a mean mass of $67.8 \mathrm{~g}$ and $67.9 \mathrm{~g}$ in 1979 and 1980 , respectively. The second type of cut seed was left ungraded and had a mean mass of $59.0 \mathrm{~g}$ and $61.1 \mathrm{~g}$ in 1979 and 1980, respectively. A sample of tubers from each seedpiece type was weighed and the mass distributions and the $\mathrm{CV}$ values for each distribution were recorded (Figs. 1 and 2). Planting dates, harvest dates and fertilizer rates were recorded and are presented in Table 17 (Appendix).

Seedtype and In-Row Spacing Experiment (cv Netted Gem); 1980. This experiment was established as a split-plot design replicated three times, with seedpiece spacing as the mainplot and seedtype as the sub-plot. The three in-row spacings were $30.4 \mathrm{~cm}, 45.7 \mathrm{~cm}$ and $60.9 \mathrm{~cm}$. Due to the large differences between the treatments used in this experiment, two guard rows were planted between rows of different spacings. The spacing of each guard row corresponded to that of the adjacent treatment. Seedtypes used in this experiment were the same as those in the previous experiment (Fig. 2). After desiccation and prior to harvest, five plants from each plot were sampled for mainstem number and basal branching. The branches were counted on the bottom $10 \mathrm{~cm}$ of the above ground portion of the mainstems. Details of the planting date, harvest date and fertilizer rates were recorded and are presented in Table 17 (Appendix). 
Figure 1. Frequency distributions of seedpiece mass for three seedtypes (a: whole, b: cut-graded, c: cut-ungraded) planted in 1979 .
a) Seed type whole
Average mass $75.2 \mathrm{~g}$
Standard deviation $22.5 \mathrm{~g}$
CV $29.8 \%$
b) Seedtype cut (graded)
Average mass $\quad 67.8 \mathrm{~g}$
Standard deviation $14.1 \mathrm{~g}$
CV $20.7 \%$
c) Seedtype cut (ungraded)
Average mass $\quad 59.0 \mathrm{~g}$
Standard deviation $11.6 \mathrm{~g}$
CV $19.6 \%$




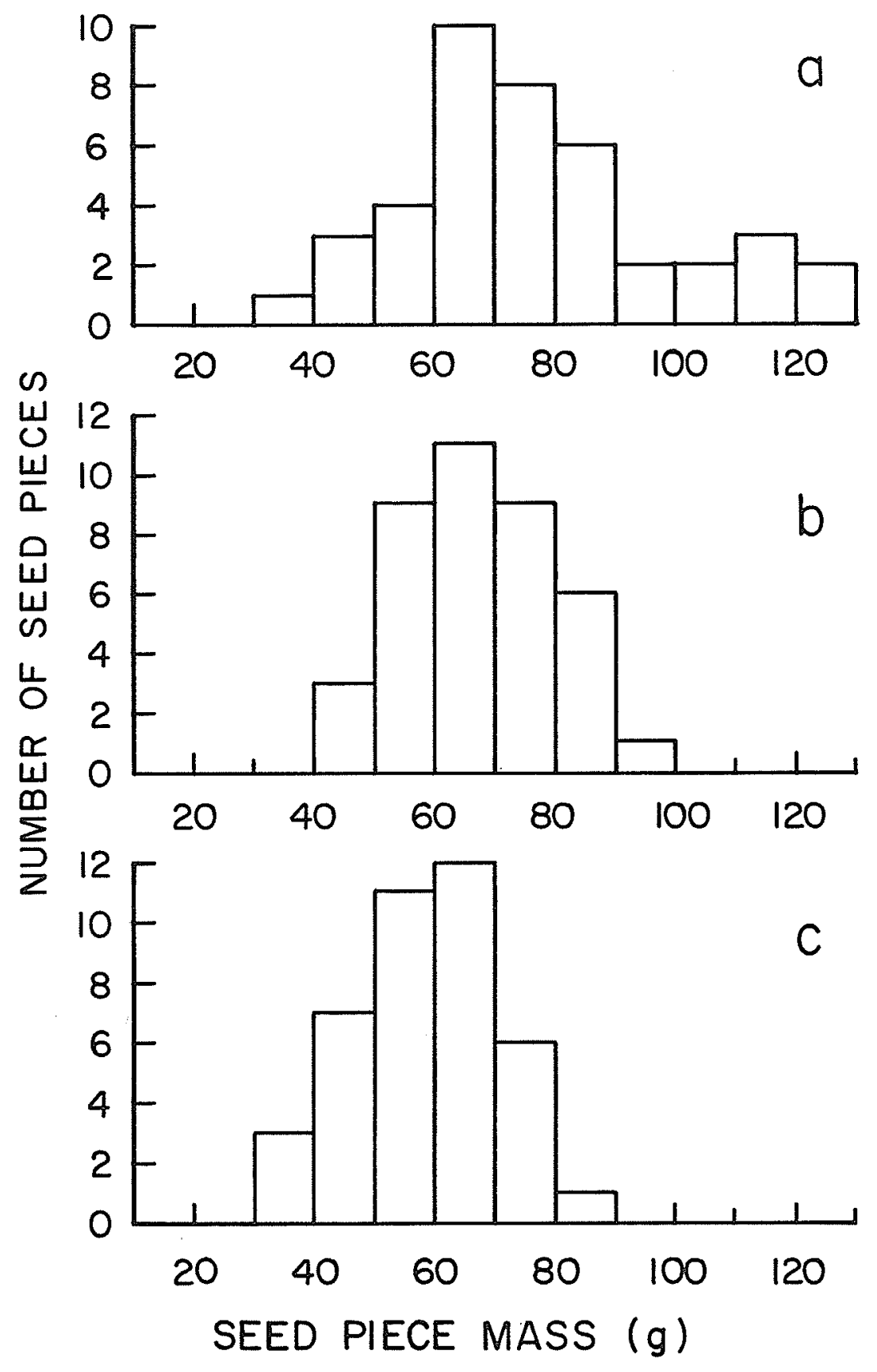


Figure 2. Frequency distributions of seedpiece mass for three seedtypes (a: whole, b: cut-graded, c: cut-ungraded) planted in 1980.
a) Seedtype
Average mass
Standard deviation
$\mathrm{CV}$
whole
$77.6 \mathrm{~g}$
$19.7 \mathrm{~g}$
$25.3 \%$
b) Seedtype
Average mass
Standard deviation
$\mathrm{CV}$
cut (graded)
$67.9 \mathrm{~g}$
$13.4 \mathrm{~g}$
$19.6 \%$
c) Seedtype
Average mass
Standard deviation
CV
cut (ungraded)
$61.2 \mathrm{~g}$
$16.9 \mathrm{~g}$
$27.6 \%$ 


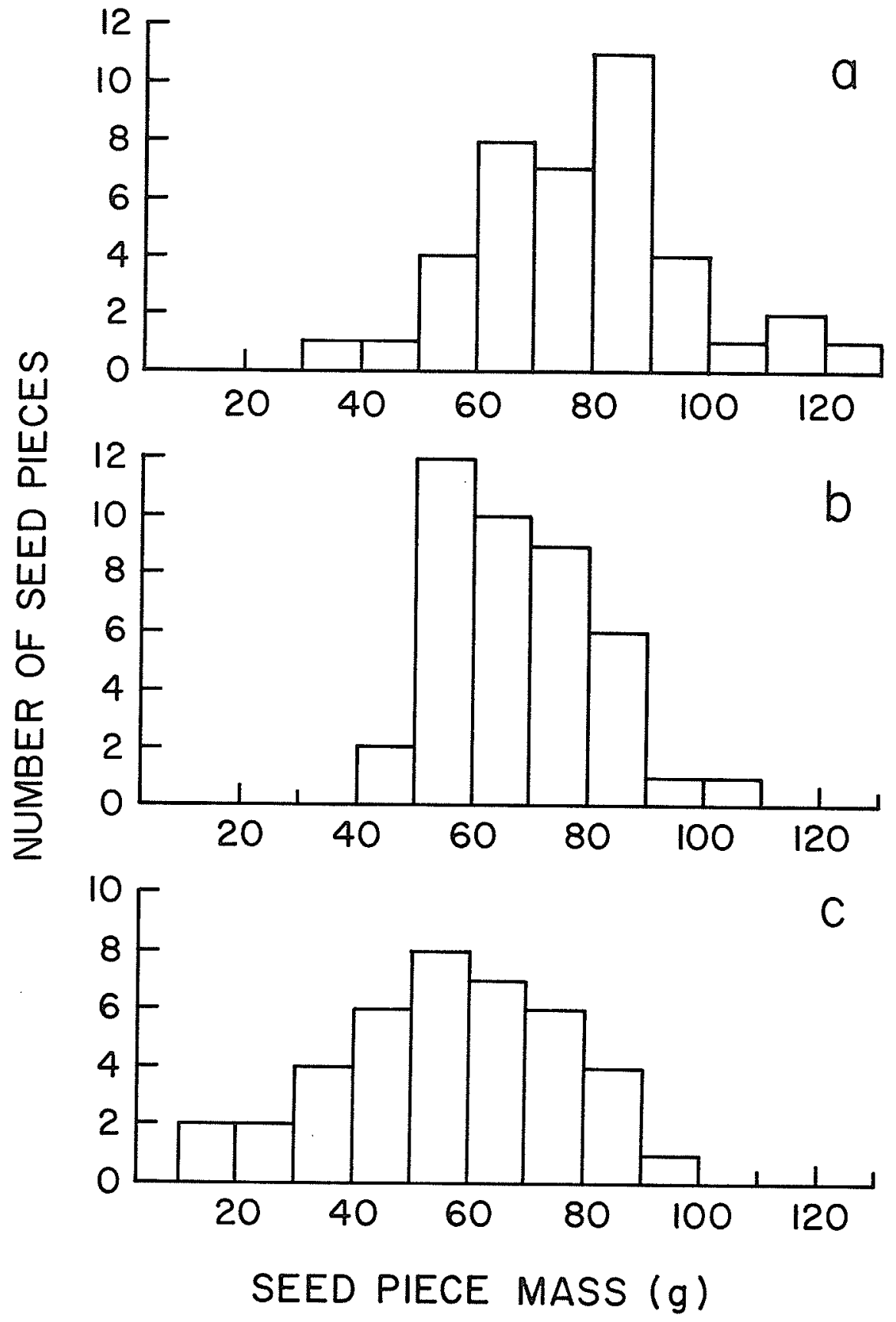


Figure 3. Frequency distributions of seedpiece mass for three seedtypes ( $a$ : cut-ungraded, b: cut-graded, c: whole) planted with a Lockwood potato planter (Model No. L06200-00603).
a) Seedtype
Average mass
Standard deviation
$\mathrm{CV}$
cut (ungraded)
$38.3 \mathrm{~g}$
$18.2 \mathrm{~g}$
$49.2 \%$
b) Seedtype
Average mass
Standard deviation
cut (graded)
CV
$59.7 \mathrm{~g}$
$21.6 \mathrm{~g}$
$36.3 \%$
c) Seedtype
Average mass
Standard deviation
CV
whole
$95.6 \mathrm{~g}$
$21.1 \mathrm{~g}$
$22.6 \%$ 


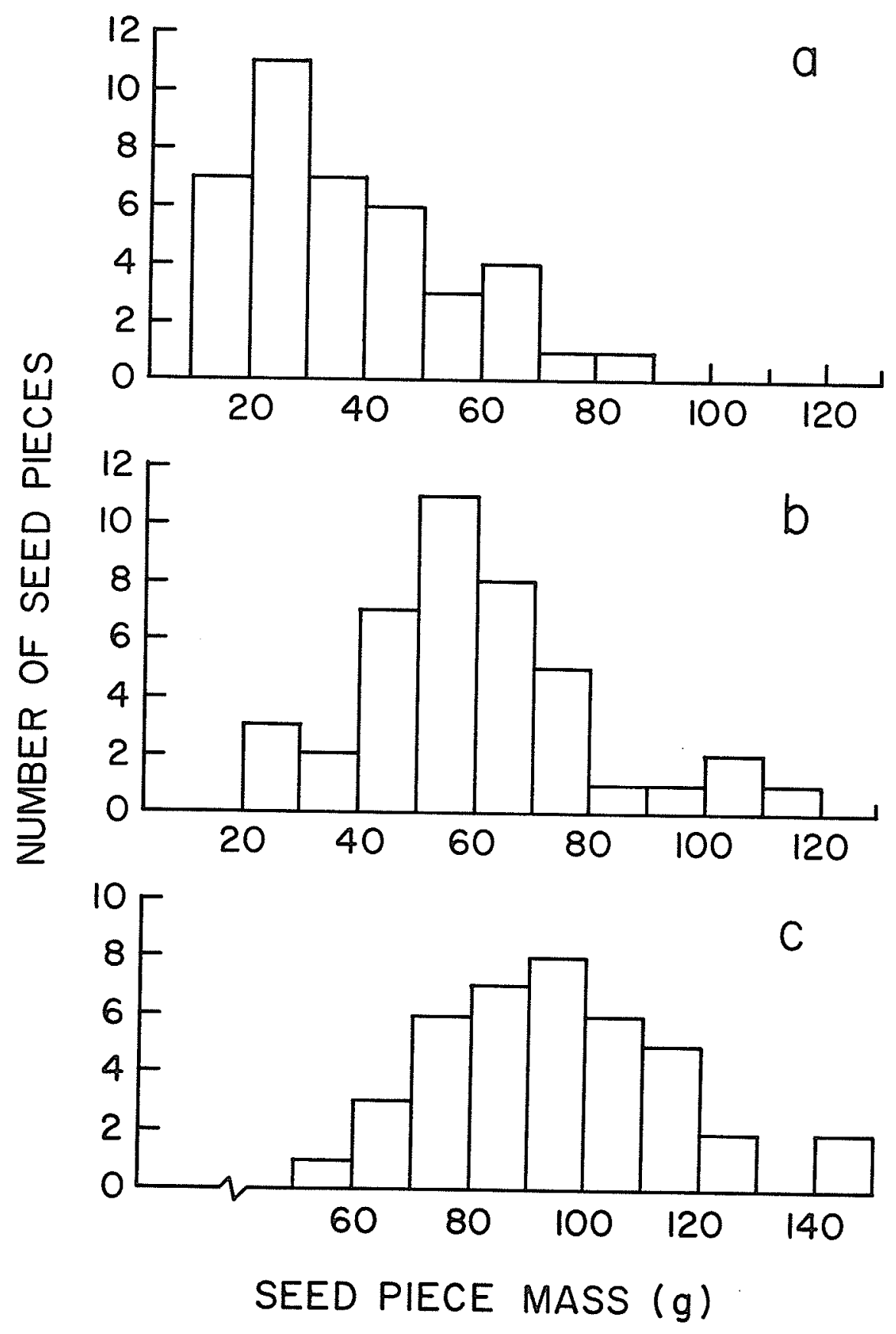


RESULTS AND DISCUSSION

\section{Planter Experiments}

The mean spacings, $\mathrm{CV}^{\prime}$ s and range of spacings recorded for each planter are presented along with the seedpiece distributions for individual planters (Figs. 4 and 5). The most striking observation made while surveying the five types of potato planters, is the lack of accuracy in seedpiece placement. This appears to be the primary reason for poor plant stands, in contradiction to suggestions by James et al. (1975) and Ohms and Cross (1967), that irregular stands were due to diseased or blind seedpieces.

From planter surveys conducted in Great Britain by Jarvis et al. (1976), it was found that the use of both the fully automated and hand-fed planters resulted in normal distributions of seedpiece spacing. Results from the present survey showed distributions to be normal for some planters, and skewed for others (Figs. 4 and 5). Some askewness to the left should be expected as there is a limit on one side of the distribution $(0 \mathrm{~cm})$. It appeared that the $\mathrm{CV}$ levels increase with the degree of askewness. For example, a fairly normal distribution was associated with a CV of $50.1 \%$ (Fig. 4a), while a CV of $76.5 \%$ was recorded for the distribution produced by the Lockwood "Accumatic" planter (Fig. 5d). The latter had a distribution which was markedly skewed due to the high percentage of doubles $^{1}$. From such an observation it could be suggested that for

${ }^{1}$ Doubles refer to any two seedpieces less than $10 \mathrm{~cm}$ apart. 
Figure 4. Seedpiece frequency distributions of in-row spacing distance for four potato planters ( $a, b, c, d)$.

a) Manufacturer

Mode1 No.

CV

Range of spacing

Set mean spacing

Actual mean spacing

Seed type

b) Manufacturer

Mode1 No.

CV

Range of spacing

Set mean spacing

Actual mean spacing

Seed type

c) Manufacturer

Model No.

CV

Range of spacing

Set mean spacing

Actual mean spacing

Seedtype

d) Manufacturer

Mode1 No.

CV

Range of spacing

Set mean spacing

Actual mean spacing

Seedtype
Lockwood

LO 6200-00623

$50.1 \%$

10.2-200.7 cm

$45.7 \mathrm{~cm}$

$47.5 \mathrm{~cm}$

cut

Lockwood

LO 6200-00603

$58.1 \%$

10.2-134.6 cm

$45.7 \mathrm{~cm}$

$41.8 \mathrm{~cm}$

cut

Lockwood

LO 6200-00623

$59.3 \%$

$5.1-150.0 \mathrm{~cm}$

$43.2 \mathrm{~cm}$

$48.1 \mathrm{~cm}$

cut/whole mixture

Lockwood

LO 6200-00623

$57.6 \%$

5.1-147. $3 \mathrm{~cm}$

$43.2 \mathrm{~cm}$

$48.1 \mathrm{~cm}$

whole 


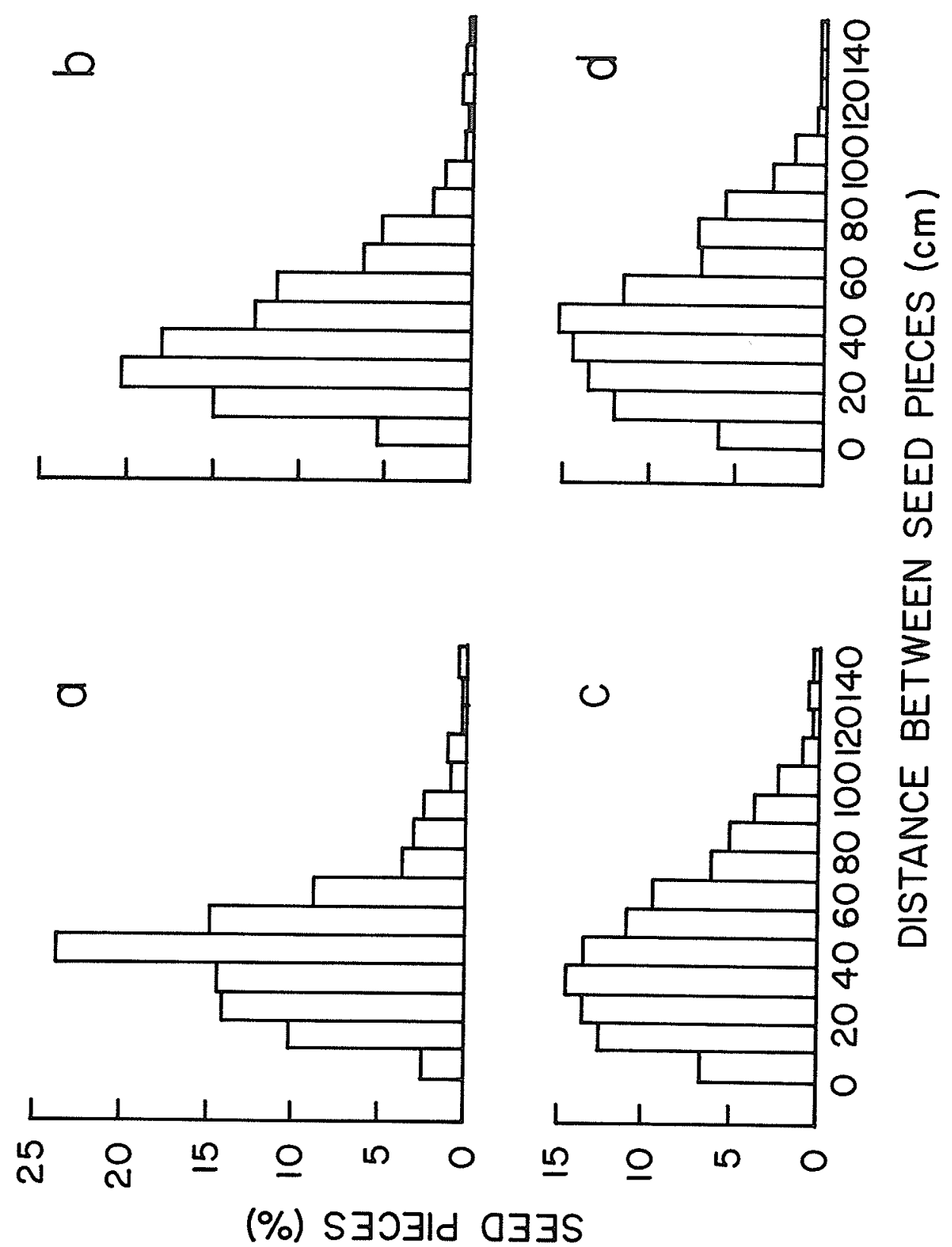


planters to be more accurate, their planting distributions would have to be close to normal.

Many of the planters had a high incidence of doubles. The percentage of doubles ranged from just over $2 \%$ (Fig. 4 a) to about $15 \%$ (Fig. 5d). Most other machines planted between 5 and $7 \%$ of the seedpieces as doubles. The effect of planters on the actual spacing versus the set spacing is not generally of great concern in this discussion, as spacing can easily be adjusted on the machine by changing the speed of the feeding-mechanism relative to the ground speed. However, when a planter is producing a high percentage of doubles, it appears that factors other than the speed of the feeding mechanism are involved.

Differences between individual planting mechanisms were observed in some instances within individual sampling areas. However, when mean values from a11 four sampling areas were calculated, no marked differences appeared.

Several comparisons were made between planters. Pick-type planters were compared to cup-type planters, as both types are popular in Manitoba. The pick-type planter utilizes a wheel with picks mounted on the periphery, to singularize seedpieces. As they rotate through a hopper of potatoes, the picks pierce the seedpieces and then release them above the opened furrow. The cup-type planter singularizes the seed by a series of cups that pass through the hopper of potatoes and selects one seedpiece per cup. Misener (1979) found the pick-type planter to be slightly more accurate than the cup-type planter. In the present survey, there appeared to be no difference between cup and pick planters.

Of the three cup-type planters surveyed (Figs. 5a, b and c), the Acme single cup planter had the lowest $\mathrm{CV}(52.0 \%)$, while the Curl single 
cup and Acme double cup planters had CV levels of $61.0 \%$ and $61.9 \%$, respectively. One of the supposed advantages of the double cup planter is its ability to plant accurately at higher speeds than a single cup machine. The reason for this claim by the manufacturer is that there are two chains (with cups) delivering seedpieces to the furrow as opposed to one in the case of the single cup planter. This allows an increased ground speed without an increase in the speed at which the cups move through the hopper. Both the Acme single and double cup planters were used by the same grower, using the same seed. The tractor speeds for the single and double cup planters were 8.0 and $12 \mathrm{~km} / \mathrm{hr}$, respectively. and were recorded in order to test the supposed high speed advantage of the double cup planter. However, in this case there appeared to be a disadvantage to using the double cup planter under these conditions (Figs. 5a and b).

Of the two models of pick-type planters surveyed, a conventional Lockwood planter, produced a distribution with the lowest CV (Fig. 4a), while a Lockwood "Accumatic" planter resulted in the poorest distribution (Fig. 5d) and a CV of 76.5\%. Another "Accumatic" planter was surveyed and appeared to perform much better than the previous one, as the $\mathrm{CV}$ was $58.1 \%$ (Fig. 4b). Another conventional Lockwood pick-type planter resulted in $\mathrm{CV}$ values of $59.3 \%$ and $57.6 \%$ (Figs. $4 \mathrm{c}$ and $\mathrm{d}$, respectively). From such observations it is clear that the conditions under which similar planters are used may significantly influence their performances. Two specific examples can be cited. A conventional pick-type planter was usejd to plant whole seed in one field and a mixture of cut and whole seed in another field. Comparison of the respective distributions (Figs. 4c and d), showed no difference in the performance of the machine. 
Figure 5. Seedpiece frequency distributions of in-row spacing distance for four potato planters ( $a, b, c, d)$.
a) Manufacturer
Model No.
Acme (single cup)
CV
660
Range of spacing
Set mean spacing
Actual mean spacing
Seedtype
$52.0 \%$
$2.5-175.3 \mathrm{~cm}$
$45.7 \mathrm{~cm}$
$51.3 \mathrm{~cm}$
cut/whole mixture
b) Manufacturer
Mode1 No.
CV
Acme (double cup)
440 - speed cup
$61.9 \%$
Range of spacing
Set mean spacing
$2.5-160.0 \mathrm{~cm}$
$45.7 \mathrm{~cm}$
Actual mean spacing
$40.6 \mathrm{~cm}$
Seed type
cut/whole mixture
c) Manufacturer
Mode1 No.
Cur1
600
CV
$61.0 \%$
Range of spacing
$2.5-226.1 \mathrm{~cm}$
Set mean spacing
$45.7 \mathrm{~cm}$
Actual mean spacing
$49.4 \mathrm{~cm}$
Seedtype
cut/whole mixture
d) Manufacturer
Mode1 No.
Lockwood
CV
LO 6200-00603
$76.5 \%$
Range of spacing
Set mean spacing
$2.5-152.4 \mathrm{~cm}$
Actual mean spacing
Seed type
$45.7 \mathrm{~cm}$
$39.2 \mathrm{~cm}$
cut 




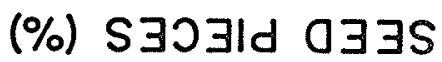


However, when comparing the two "Accumatic" planters (Figs. 4b and 5d), there is an approximate $22 \%$ difference in $\mathrm{CV}$ values. Although no samples were taken from the respective seedlots, it appeared that the seedpieces used in each case differed greatly in both size and uniformity. This may have been the reason for differences in the performance of the two machines.

Results from the present survey are comparable to those from previous surveys. For instance, Andrew et a1. (1968) and Misener (1979) found similar CV values for both pick-type and cup-type planters. Automated potato planters used in Great Britain resulted in CV values from 60-65\% (Jarvis and Palmer, 1973; Pascal et al., 1977), while the hand-fed machines had CV values from 18 to $40 \%$ (Shotton, 1976).

As was mentioned earlier, seedpiece type may influence planter performance. Results from the experiment with a Lockwood "Accumatic" planter and three seedtypes confirmed this. The experiment was also useful as an opportunity to evaluate a planter under somewhat more controlled conditions, as all previous surveysfields were planted under a number of different conditions.

The actual spacing, $\mathrm{CV}$ and range of spacing are presented along with the seedpiece distributions for the respective seedtypes in Figure 6.

The CV levels resulting from seedpiece distributions by the planter varied considerably. CV values of $56.6 \%$ and $59.4 \%$ were recorded for the cut (hand-graded) and whole seed, respectively, while the cut (ungraded) seed resulted in a CV of $75.0 \%$ (Figs. $6 \mathrm{~b}$, a and $\mathrm{c}$, respectively). One obvious result was the effect of increases in seedpiece mass on the mean spacing. The average mass of the three seedtypes were $38.3 \mathrm{~g}, 59.6 \mathrm{~g}$ and $95.6 \mathrm{~g}$, respectively (Fig. 3). The corresponding mean spacings were 33.2 , 
46.2 and $56.9 \mathrm{~cm}$, respectively (Figs. $6 \mathrm{a}, \mathrm{b}$ and $\mathrm{c}$, respectively). As mentioned earlier, the actual mean spacings recorded from planters are not of great importance in this discussion. However, such market differences as those recorded above, warrant some explanation. The highest percentage of doubles recorded anywhere in the entire survey occurred in this experiment when the cut (ungraded) seedtype was used. It appears that the pick mechanism was the reason for the high percentage of doubles recorded here. This mechanism appeared to be designed to hold one average sized seedpiece (approximately 60 to $80 \mathrm{~g}$ ). During the planting of the small seedtype, it was frequently observed that more than one seedpiece was being planted by one pick. This may also be the reason for the distribution from the cut (hand-graded) seed to produce $12 \%$ doubles, whereas only $5.6 \%$ of the seedpieces were spaced in the $10-20 \mathrm{~cm}$ category (Fig. 6b). The latter seedtype also contained a percentage of small seedpieces (Fig. 3b) which could be affected by the pick-mechanism. Therefore, with this planter, it appears that the pick mechanism becomes an additional factor to uniform planting when a portion of the seedpieces in a seedlot are sma11.

James et a1. (1973) reported that $7 \%$ of missing seedpieces within a row were due to the rolling of seedpieces, which resulted in doubles. It may be that the 2.0 to $7.0 \%$ of doubles recorded with many of the planters surveyed, were due to this rolling of seedpieces. All instances in which higher percentages of doubles were recorded, were with the Lockwood "Accumatic planter. Therefore, it could be that levels of doubles higher than approximately $8 \%$, were due to problems with the pick-mechanism.

The actual spacing was much higher than the set spacing when the whole seedpieces were planted in this experiment (Fig. 6c). It should 
Figure 6. Seedpiece frequency distributions of in-row spacing distance for three seedtypes ( $a$ : whole, b: cut-graded, c: cut-ungraded) using a Lockwood potato planter (Model No. LO 6200-00603).
a) Seed type
whole
CV
$50 \%$
Range of spacing
$2.5-181.2 \mathrm{~cm}$
Set mean spacing
$45.7 \mathrm{~cm}$
Actual mean spacing
$56.6 \mathrm{~cm}$
b) Seed type
cut (graded)
Range of spacing
$51 \%$
Set mean spacing
$21.5-149.1 \mathrm{~cm}$
Actual mean spacin
$45.7 \mathrm{~cm}$
$47.8 \mathrm{~cm}$
c) Seedtype
cut (ungraded)
CV
$79 \%$
Range of spacing
$2.5-124.5 \mathrm{~cm}$
Set mean spacing
$45.7 \mathrm{~cm}$
Actual mean spacing $30.6 \mathrm{~cm}$ 

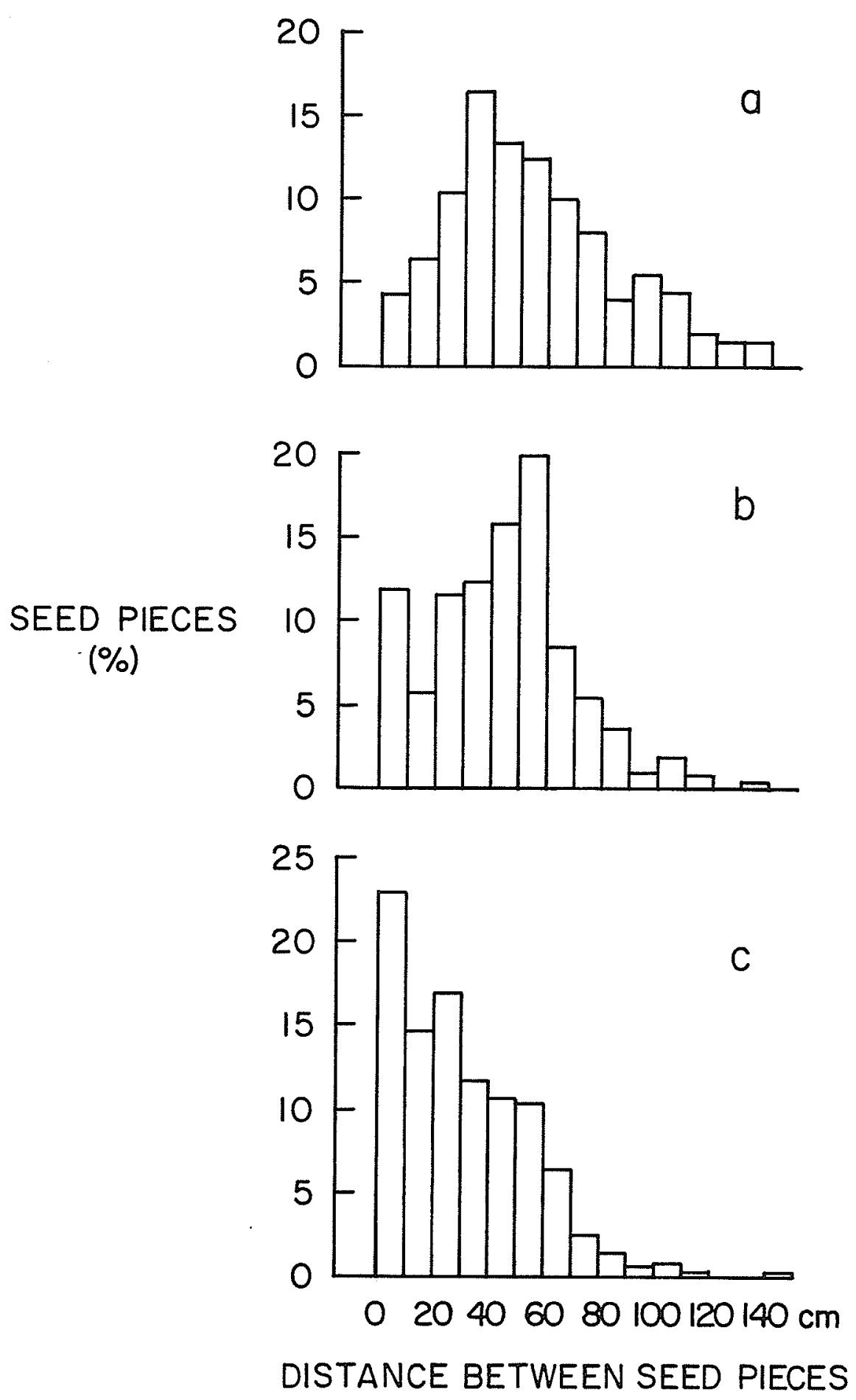
be noted that the whole seed used in the experiment was about $20 \mathrm{~g}$ heavier than that used in commercial production. The whole seed appeared to be too large for the pick-mechanism, as it was frequently observed that the mechanism had difficulty in securing large seed tubers. In many instances, large seed potatoes fell back into the hopper before they could be dropped into the furrow.

In addition to having different mean mass, the seedtypes tested varied in their frequency distribution of mass (Fig. 3). The most dramatic difference in mass was between the whole seed, with a CV of $22.6 \%$ and the cut (ungraded) seed, with a CV of $49.2 \%$. The planting distributions were quite different for these two seedtypes (Figs. 6a and b) with CV values of 59.4 and $76.0 \%$, respectively. In this experiment, it may be difficult to separate the effects of seedpiece uniformity from seedpiece size, in terms of their effects on planting accuracy. As a seedlot was graded to eliminate small seedpieces, its average mass changed. However, from this experiment, it appeared that both factors significantly affected the performance of the Lockwood "Accumatic".

Results from this experiment support reports by Palmer (1976), Jarvis and Shotton (1976) and Pascal et al. (1977), who all observed more accurate planting when seedpieces were round and more uniform in size. Pascal et al. (1977) also found that CV values were higher for fully automated planters than they were for hand-fed planters. In the case of hand-fed planters, the individual assisting the machine will ensure that each seed-cup delivers one, and only one, seedpiece into the furrow. Therefore, the feeding mechanism of the fully automated machines appeared to be contributing to non-uniform planting.

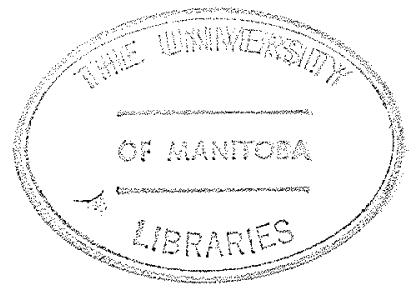




\section{Field Experiments}

Experiment 1

This experiment was carried out at two locations in 1979 and 1980.

Few differences were observed between locations in a given year, however, there were marked differences between years. It appeared that much of the variation between years was due to the differences in rainfal1 patterns for the respective years (Tables 15 and 16, Appendix).

In 1980, four CV levels were tested. Although plots were planted at four CV levels in 1979, only the results from the 0,25 and $50 \% \mathrm{CV}$ levels will be reported. In 1979, the mean spacing for plots with $\mathrm{CV}$ levels of $75 \%$ was higher than for the other treatments due to an error in calculating planting distances. Therefore, the results from the $75 \%$ CV treatment in 1979 were not meaningful relative to the other CV levels. Al1 plots were planted at the same mean spacing in 1980.

The two main effects (CV and seedtype) generally affected the crop independent1y as there were no significant interactions (Tables 18, 19, 20 and 21, Appendix). Therefore, the main effects will be discussed separately.

The effects of the three seedtypes on tuber production and yield were similar for locations within a given year. However, results between years were quite different; in several instances the trends produced by the respective seedtypes were opposite for the two years. One observation which was universal for all locations in both years is that the tota1 numbers of tubers produced per plot decreased with decreasing seedpiece weight (Fig. 7). At Barnsley in 1979, the whole seed (seedtype A) produced significantly more tubers than the other two seedtypes, whereas at Carman in 1979, there were no significant differences (Table 1). 


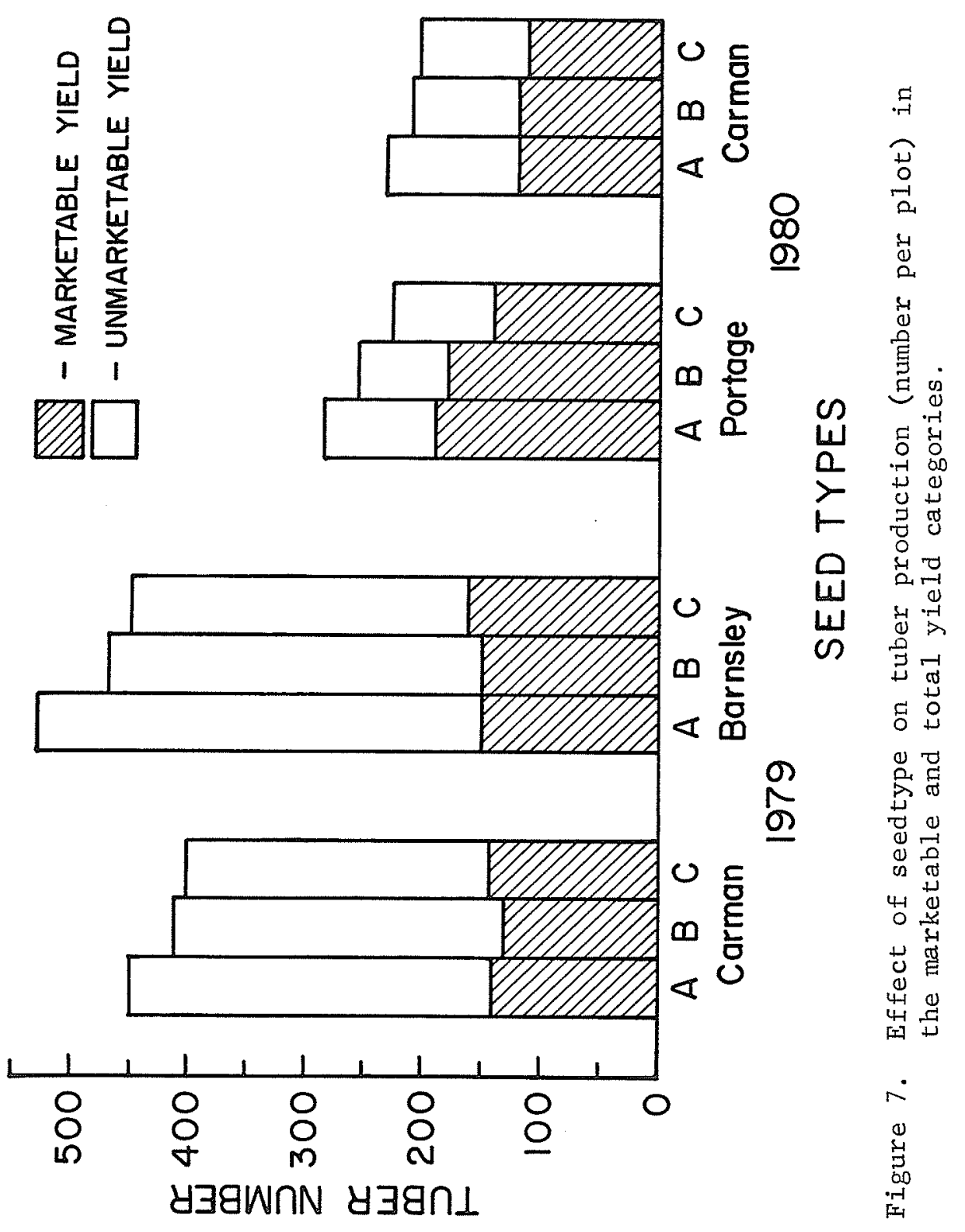


TABLE 1. Effect of seedtype on production (number per plot) and yield ( $\mathrm{kg}$ per plot) of tubers in the marketable and total yield categories.

\begin{tabular}{|c|c|c|c|c|c|}
\hline & \multirow[b]{3}{*}{ Seedtype } & \multicolumn{4}{|c|}{ Marketable Yield } \\
\hline & & \multicolumn{2}{|c|}{ Carman } & \multicolumn{2}{|c|}{ Barnsley } \\
\hline & & Number & Yield & Number & Yield \\
\hline \multirow[t]{4}{*}{1979} & Whole & $136.9 \mathrm{a}^{1}$ & $25.3 \mathrm{a}$ & $148.3 \mathrm{a}$ & $23.9 \quad \mathrm{~b}$ \\
\hline & Cut (graded) & $128.8 \mathrm{a}$ & $24.9 \mathrm{a}$ & $151.0 \mathrm{a}$ & $26.9 \mathrm{ab}$ \\
\hline & Cut (ungraded) & $143.6 \mathrm{a}$ & $27.9 \mathrm{a}$ & $163.7 \mathrm{a}$ & $29.1 \mathrm{a}$ \\
\hline & & \multicolumn{2}{|c|}{ Portage } & \multicolumn{2}{|c|}{ Carman } \\
\hline \multirow[t]{5}{*}{1980} & Whole & $189.5 \mathrm{a}$ & $40.1 \mathrm{a}$ & $122.6 \mathrm{a}$ & $27.6 \mathrm{a}$ \\
\hline & Cut (graded) & $177.3 \mathrm{a}$ & $40.6 \mathrm{a}$ & $119.7 \mathrm{a}$ & $27.7 \mathrm{a}$ \\
\hline & Cut (ungraded) & $141.7 \quad b$ & $32.5 \quad b$ & $113.5 \mathrm{a}$ & $26.6 \mathrm{a}$ \\
\hline & & \multicolumn{4}{|c|}{ Total Yield } \\
\hline & & \multicolumn{2}{|c|}{ Carman } & \multicolumn{2}{|c|}{ Barnsley } \\
\hline \multirow[t]{4}{*}{1979} & Whole & $450.4 a$ & $47.3 \mathrm{a}$ & 529.1 a & $52.5 \mathrm{a}$ \\
\hline & Cut (graded) & $413.1 \mathrm{a}$ & $46.6 \mathrm{a}$ & $468.0 \quad b$ & 50.9 a \\
\hline & Cut (ungraded) & $404.0 \mathrm{a}$ & $49.0 \mathrm{a}$ & $446.4 \quad b$ & $51.9 \mathrm{a}$ \\
\hline & & \multicolumn{2}{|c|}{ Portage } & \multicolumn{2}{|c|}{ Carman } \\
\hline$\underline{1980}$ & Whole & $283.7 \mathrm{a}$ & $48.4 a$ & $234.6 \mathrm{a}$ & $37.7 \mathrm{a}$ \\
\hline & Cut (graded) & $255.7 \quad b$ & $47.3 \mathrm{a}$ & $211.6 \mathrm{~b}$ & $35.9 \mathrm{ab}$ \\
\hline & Cut (ungraded) & 230.8 & $39.6 \quad b$ & $205.5 \mathrm{~b}$ & $34.5 \mathrm{~b}$ \\
\hline
\end{tabular}

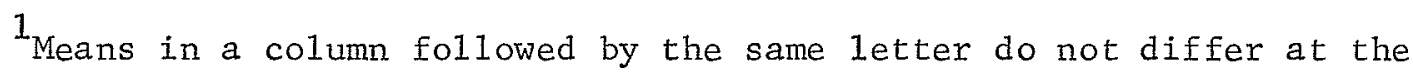
$5 \%$ level of significance. 
Similar but more marked differences between seedtypes were observed in 1980 (Table 1). At Portage la Prairie, the total tuber number decreased significantly with each decrease in seedpiece mass. At Carman, the whole seedtype produced significantly more tubers than the other two seedtypes. These observations support those by Roer (1955), Taha (1961) and Scott and Younger (1972), who all reported that production of tubers increased with increasing seedpiece size. In 1979, there were no significant differences between seedtypes, in terms of the number of marketable tubers (Fig. 7; Table 1). However, there was a slight increase in the number of marketable tubers with decreasing seedpiece mass. In addition, the number of unmaiketable tubers produced by seedtype $C$ (cut-ungraded seed) were significantly lower $(P=0.05)$ than those produced by seedtype A (Table 2). These observations were made at both locations in 1979 and confirm reports by Harris (1978).

In 1980, the number of marketable tubers per plot generally decreased with decreasing seedpiece mass (Fig. 7). At Portage la Prairie, seedtype C had significantly fewer marketable tubers than the two larger seedtypes, while at Carman no significant differences were observed (Table 1). The effects of seedtype on the number of unmarketable tubers in 1980 were similar to those in 1979. At both locations, seedtype A produced a higher number of unmarketable tubers than the other two seedtypes (Table 2), however, the difference was only significant at the Carman site.

Overall tuber production per plot was almost twice as high in 1979 than in 1980. The differences may have been due to the apparent differences in soil moisture conditions at the time of tuberization (Tables 15 and 16, Appendix). Tuber initiation in 1979 took place under relatively moist conditions while in 1980 it took place when there was little moisture 
TABLE 2. Effects of seedtype and in-row variation in spacing on production (number per plot) and yield ( $\mathrm{kg}$ per plot) of tubers in the unmarketable grade.

\begin{tabular}{|c|c|c|c|c|c|}
\hline & \multirow[b]{2}{*}{ Seed type } & \multicolumn{2}{|c|}{ Carman } & \multicolumn{2}{|c|}{ Barnsley } \\
\hline & & Number & Yield & Number & Yield \\
\hline \multirow[t]{4}{*}{1979} & Whole & $313.5 \mathrm{a}^{1}$ & $22.1 \mathrm{a}$ & $380.8 \mathrm{a}$ & $28.6 \mathrm{a}$ \\
\hline & Cut (graded) & $284.3 \mathrm{ab}$ & $21.8 \mathrm{a}$ & $316.9 \mathrm{ab}$ & $24.1 \quad b$ \\
\hline & Cut (ungraded) & $260.4 \quad b$ & $21.1 \mathrm{a}$ & $285.4 \quad \mathrm{~b}$ & $22.9 \quad b$ \\
\hline & & \multicolumn{2}{|c|}{ Portage } & \multicolumn{2}{|c|}{ Carman } \\
\hline \multirow[t]{5}{*}{1980} & Whole & 95.2 a & $8.5 \mathrm{a}$ & $111.9 \mathrm{a}$ & $10.1 \mathrm{a}$ \\
\hline & Cut (graded) & $80.0 \mathrm{a}$ & $7.4 \mathrm{a}$ & $91.9 \quad b$ & $8.2 \mathrm{~b}$ \\
\hline & Cut (ungraded) & $84.0 \mathrm{a}$ & $7.0 \mathrm{a}$ & $91.9 \mathrm{~b}$ & $7.7 \mathrm{~b}$ \\
\hline & & \multicolumn{2}{|c|}{ Carman } & \multicolumn{2}{|c|}{ Barnsley } \\
\hline & $\mathrm{CV} \quad(\%)$ & Number & Yield & Number & Yield \\
\hline \multirow[t]{4}{*}{1979} & 0 & $281.4 \mathrm{a}$ & $22.6 \mathrm{a}$ & $302.0 \mathrm{a}$ & $25.9 \mathrm{a}$ \\
\hline & 25 & $287.0 \mathrm{a}$ & $21.5 \mathrm{a}$ & $334.9 \mathrm{a}$ & $25.9 \mathrm{a}$ \\
\hline & 50 & $289.8 \mathrm{a}$ & $20.8 \mathrm{a}$ & $346.1 \mathrm{a}$ & $23.6 \mathrm{a}$ \\
\hline & & Port & & Car & \\
\hline \multirow[t]{4}{*}{$\underline{1980}$} & 0 & $95.2 \mathrm{a}$ & $8.3 \mathrm{a}$ & $105.2 \mathrm{a}$ & $9.3 \mathrm{a}$ \\
\hline & 25 & $80.6 \mathrm{a}$ & $7.2 \mathrm{a}$ & $94.2 \mathrm{a}$ & $8.1 \mathrm{a}$ \\
\hline & 50 & $87.9 \mathrm{a}$ & $7.6 \mathrm{a}$ & $102.0 \mathrm{a}$ & $9.2 \mathrm{a}$ \\
\hline & 75 & $81.8 \mathrm{a}$ & $7.4 \mathrm{a}$ & $92.8 \mathrm{a}$ & $8.0 \mathrm{a}$ \\
\hline
\end{tabular}

$1_{\text {Means in a column followed by the same letter do not differ at }}$ the $5 \%$ level of significance. 
in the soil. Similar observations were reported by Svensson (1973) and Storey and Barry (1976). Although tuber production varied greatly between years, the numbers of marketable tubers were relatively similar for both years (Figs. 7 and 9). Differences in tuber production between the two years is not reflected in the total or marketable yields, as they were also rèlatively similar for both years (Figs. 8 and 10). This was due to both the relative decrease in unmarketable tubers in 1980 (Table 2) and the higher yield of over-size tubers in 1980 as compared to 1979 (Table 4).

In 1979 , there was a general increase in marketable yield with decreasing seedpiece size (Fig. 8). The difference between the largest and smallest seedtype was significant at Barnsley (Table 1). Higher yields for crops grown from smaller seedpieces relative to crops grown from larger seedpieces have also been found by Reestman and Dewit (1959) and Taha (1961)。Seedtypes had no significant effects on total yield at either location in 1979 (Table 1). The effects of seedtypes on total and marketable yield were almost reversed in 1980. The total yields for seedtype $\mathrm{C}$ were significantly lower than for the largest seedtype at both Carman and Portage la Prairie (Table 1). Such observations were confirmed by Jarvis and Shotton (1971). At Portage 1a Prairie, the marketable yield was significantly higher for seedtype A than for seedtype C, however, no differences were observed at Carman (Table 1).

Increasing CV levels generally had little effect on the crop in 1979 (Figs. 9 and 10). However, there were slight increases in the number of marketable tubers as the CV level increased. At both Barnsley and Carman, there were decreases (not significant at $\mathrm{P}=.05$ ) in total and marketable tuber production at a ov of $0 \%$ as compared to 25 and $50 \%$ 


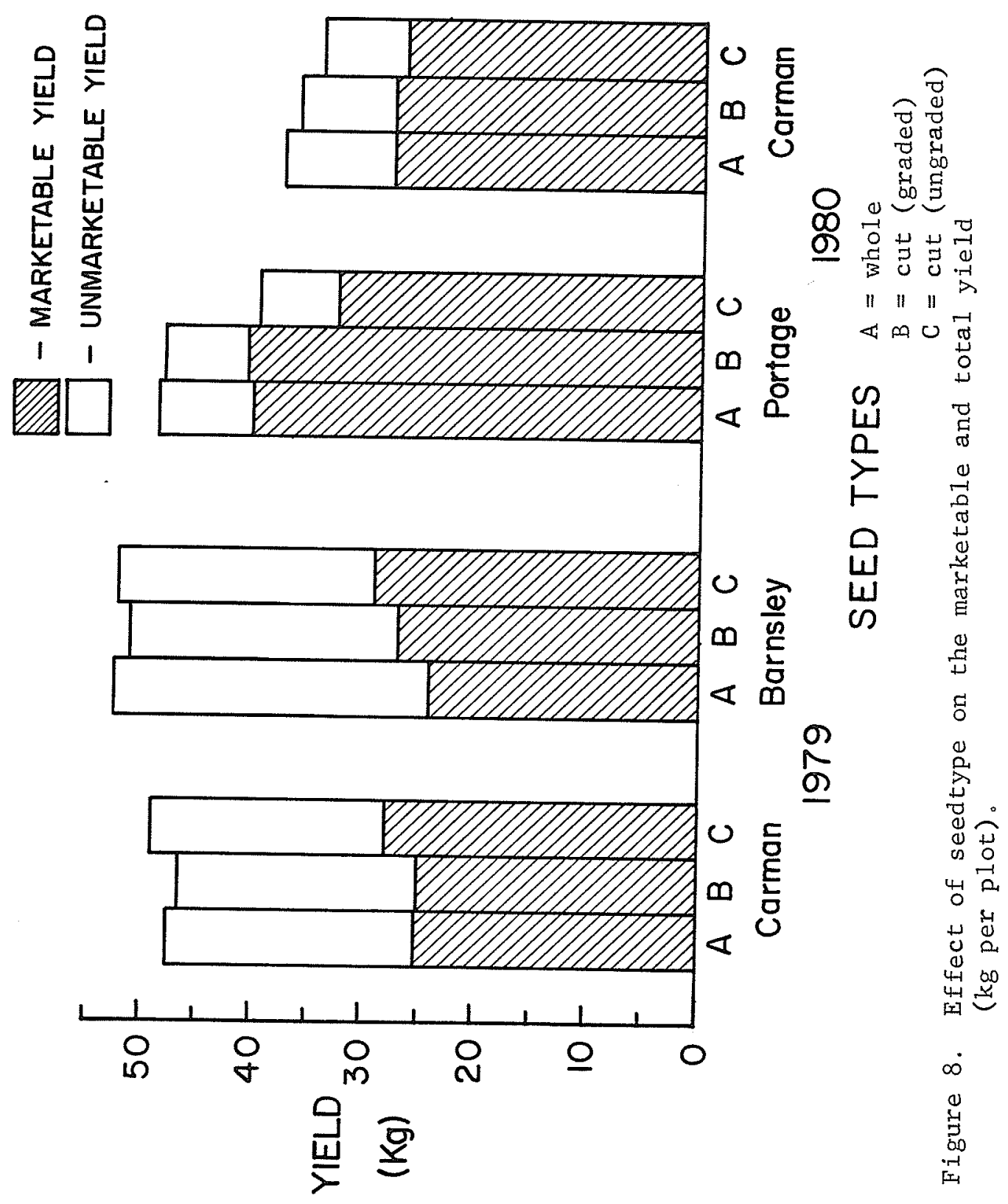


(Table 3). Similarly, no significant differences were recorded for the CV effect on total and marketable yield at either location (Table 3) and confirm observations by Schepers (1975).

The effects of CV levels were more pronounced in 1980 (Figs. 9 and 10). At Portage la Prairie, increased CV resulted in no visible trends, however, differences were observed in several instances. Tuber production in both the marketable and total yield categories, was highest at the 25 and $75 \%$ CV levels. Similar, but more marked differences were observed for total and marketable yields. No significant differences were observed for CV effects at this location (Table 3). Results from the Portage 1a Prairie location are similar to those reported by Jarvis et al. (1976). The effects of increasing CV levels resulted in more consistent trends at Carman, as the tuber production and yield generally decreased with increasing CV (Figs. 9 and 10). Total tuber production was significantly lower at a CV of $75 \%$ than for the $0 \% \mathrm{CV}$ level (Table 3). Although the number of marketable tubers decreased with every increase in CV (Table 3), differences were not significant. The total and marketable yields at the Carman site were also reduced by irregular spacing. Yields decreased 25 and $22 \%$, respectively, as the $\mathrm{CV}$ increased from 0 to $75 \%$. However, the differences were not found to be significant (Table 3). This is the only location at which there was a consistent trend in the effect of irregular spacing on a change in marketable and total yields. Similar observations have been made by Jarvis and Palmer (1973) and Pascal et a1. (1977).

Some evidence has shown that changes in the spatial arrangement of potato plants can affect the weight and size distributions of the crop resulting in a relatively lower yield in the mid-size grade (Schepers, 1975), However, this does not appear to be the case in this experiment. 


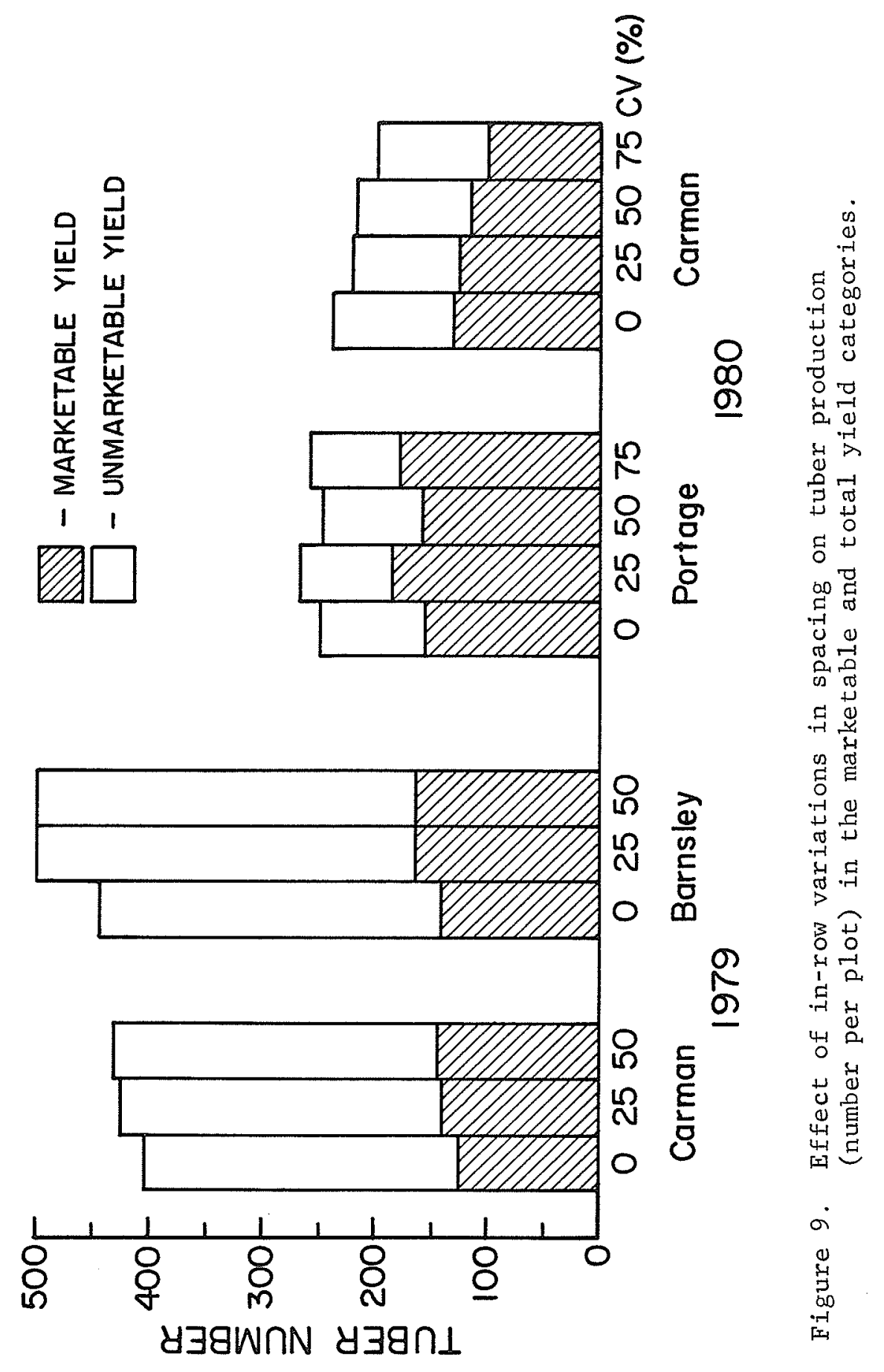




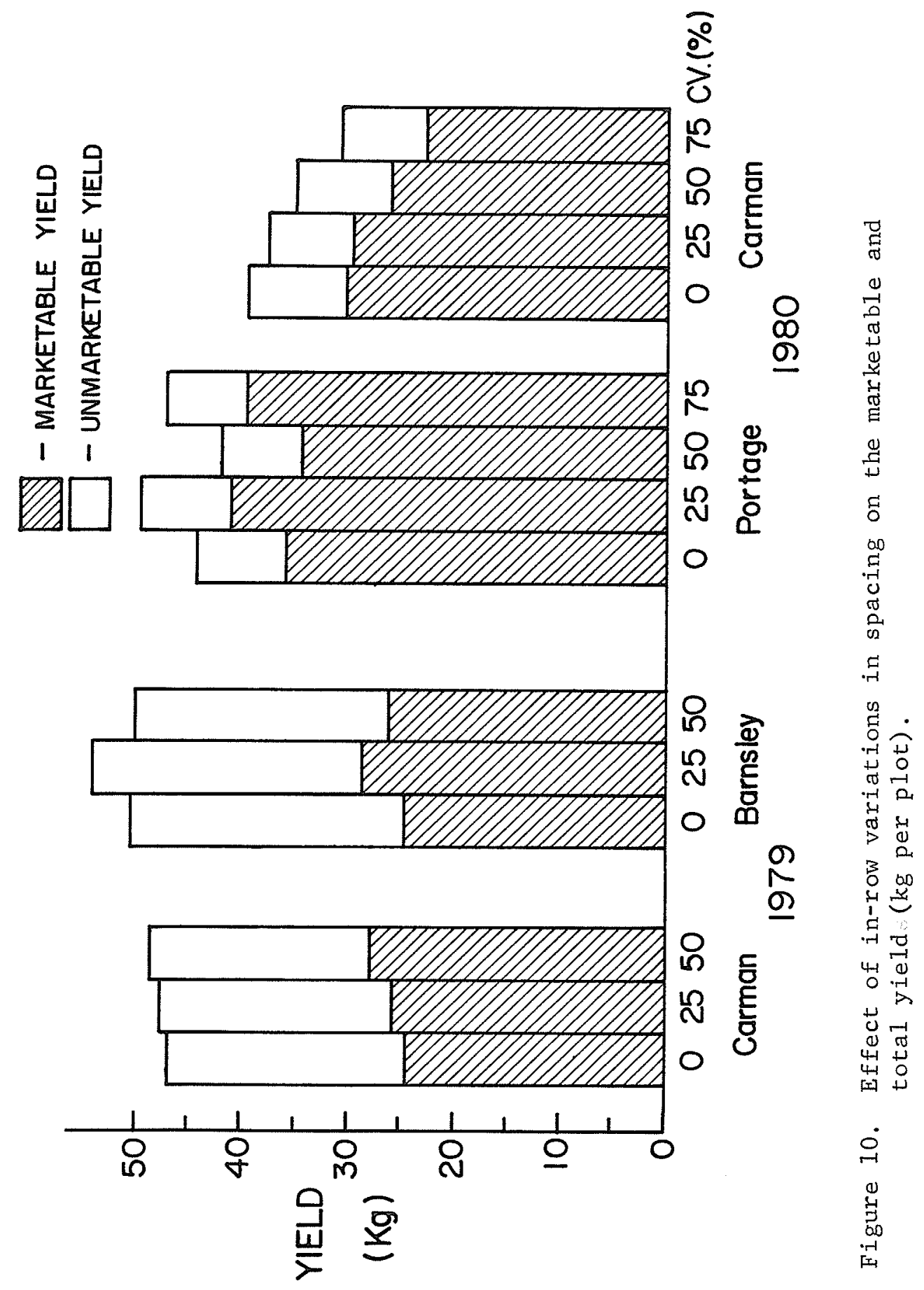


TABLE 3. Effect of in-row variation in spacing on production (number per plot) and yield ( $\mathrm{kg}$ per plot) of tubers in the marketable and total yield categories.

\begin{tabular}{|c|c|c|c|c|c|}
\hline & \multirow[b]{3}{*}{$\mathrm{CV}(\%)$} & \multicolumn{4}{|c|}{ Marketable Yield } \\
\hline & & \multicolumn{2}{|c|}{ Carman } & \multicolumn{2}{|c|}{ Barnsley } \\
\hline & & Number & Yield & Number & Yield \\
\hline \multirow[t]{4}{*}{1979} & 0 & $126.3 \mathrm{a}^{1}$ & $24.5 \mathrm{a}$ & $142.5 \mathrm{a}$ & $24.7 \mathrm{a}$ \\
\hline & 25 & $139.5 \mathrm{a}$ & 25.9 a & $164.0 \mathrm{a}$ & $28.5 \mathrm{a}$ \\
\hline & 50 & $143.5 \mathrm{a}$ & $27.7 \mathrm{a}$ & 155.8 a & $26.3 \mathrm{a}$ \\
\hline & & \multicolumn{2}{|c|}{ Portage } & \multicolumn{2}{|c|}{ Carman } \\
\hline \multirow[t]{7}{*}{$\underline{1980}$} & 0 & $155.5 \mathrm{a}$ & 35.9 a & $132.8 \mathrm{a}$ & $30.4 \mathrm{a}$ \\
\hline & 25 & $185.7 \mathrm{a}$ & 41.1 a & $125.8 \mathrm{a}$ & $29.7 \mathrm{a}$ \\
\hline & 50 & $159.9 \mathrm{a}$ & $34.4 \mathrm{a}$ & $115.4 \mathrm{a}$ & $26.1 \mathrm{a}$ \\
\hline & 75 & $177.0 \mathrm{a}$ & $39.4 \mathrm{a}$ & $100.5 \mathrm{a}$ & $22.9 \mathrm{a}$ \\
\hline & & \multicolumn{4}{|c|}{ Total Yield } \\
\hline & & \multicolumn{2}{|c|}{ Carman } & \multicolumn{2}{|c|}{ Barnsley } \\
\hline & & Number & Yield & Number & Yield \\
\hline \multirow[t]{4}{*}{$\underline{1979}$} & 0 & 407.7 a & $47.0 \mathrm{a}$ & $444.6 \mathrm{a}$ & 50.7 a \\
\hline & 25 & 426.5 a & $47.5 \mathrm{a}$ & 499.0 a & $54.5 \mathrm{a}$ \\
\hline & 50 & $433.4 \mathrm{a}$ & $48.5 a$ & 504.8 a & $50.0 \mathrm{a}$ \\
\hline & & \multicolumn{2}{|c|}{ Portage } & \multicolumn{2}{|c|}{ Carman } \\
\hline \multirow[t]{4}{*}{$\underline{1980}$} & 0 & $249.7 \mathrm{a}$ & $44.2 \mathrm{a}$ & $238.0 \mathrm{a}$ & $39.6 \mathrm{a}$ \\
\hline & 25 & 251.7 a & $48.5 \mathrm{a}$ & $220.1 \mathrm{ab}$ & $37.9 \mathrm{a}$ \\
\hline & 50 & 249.6 a & 41.9 a & $217.5 \mathrm{ab}$ & 35.4 a \\
\hline & 75 & $250.8 \mathrm{a}$ & 46.9 a & $193.4 \mathrm{~b}$ & 30.9 a \\
\hline
\end{tabular}

$1_{\text {Means in a column followed by the same letter do not differ }}$ at the $5 \%$ leve1 of significance. 
Changes in the tuber production and yield in the mid-size grade due to increasing CV levels, appeared to be proportional to the changes in total tuber production and yield. For example, effects of CV on tuber production and yield at Carman in 1980, were very similar for the mid-size grade (Table 5) and the respective totals (Table 3 ). In addition, increasing $\mathrm{CV}$ levels at this location also resulted in proportional decreases of oversized tubers (Table 4). Similar trends were found at all other locations, therefore, it did not appear that irregular spacing resulted in any significant changes in the weight and size distribution of a crop.

The overall production of over-sized tubers was highest in 1980 . In 1979 , less than $16 \%$ of the marketable yield was in the over-size category while in 1980 about $30 \%$ of the marketable yield was over-sized (Table 4). This difference appeared to be due to better moisture conditions during the period of tuber bulking in the latter year. These observations were supported by Iritani et al. (1972) who reported significant year interactions with respect to over-size tuber production.

The incidence of hollow heart varied greatly within a given location. This is reflected in the high experimental CV values which are presented along with the analysis of variance in Table 22 (Appendix). The high experimental CV values may indicate the sample size (24 tubers per plot) was too sma11, or may also be a result of the somewhat erratic nature of this disorder. The CV seedtype interactions were not significant for hollow heart at any of the locations (Table 22, Appendix). As was the case with many other measurements made in experiment 1 , the percentage of hollow heart was markedly different between years; percentages being much greater in 1979. These observations support those by Ne1son et al. (1979). Plant spacing has also been shown to be an important factor in 
TABLE 4. Effects of seedtype and in-row variation in spacing on production (number per plot) and yield (kg per plot) of tubers in the over-size grade.

\begin{tabular}{|c|c|c|c|c|c|}
\hline & \multirow[b]{2}{*}{ Seedtype } & \multicolumn{2}{|c|}{ Carman } & \multicolumn{2}{|c|}{ Barnsley } \\
\hline & & Number & Yield & Number & Yield \\
\hline \multirow[t]{4}{*}{1979} & Whole & $8.5 \mathrm{a}^{1}$ & $3.2 \mathrm{a}$ & $5.8 \mathrm{a}$ & $2.2 \mathrm{a}$ \\
\hline & Cut (graded) & $10.5 \mathrm{a}$ & $3.9 \mathrm{ab}$ & $8.5 \mathrm{a}$ & $3.1 \mathrm{a}$ \\
\hline & Cut (ungraded) & $12.7 \mathrm{a}$ & $4.9 \mathrm{~b}$ & $9.5 \mathrm{a}$ & $3.5 \mathrm{a}$ \\
\hline & & Po & ge & $\mathrm{Ca}$ & an \\
\hline \multirow[t]{5}{*}{1980} & Whole & $24.7 \mathrm{a}$ & $8.9 \mathrm{~b}$ & $22.0 \mathrm{a}$ & $8.5 \mathrm{a}$ \\
\hline & Cut (graded) & 31.8 a & $12.4 \mathrm{a}$ & $23.3 \mathrm{a}$ & $8.9 \mathrm{a}$ \\
\hline & Cut (ungraded) & $26.2 \mathrm{a}$ & $9.9 \mathrm{~b}$ & $23.1 \mathrm{a}$ & $8.9 \mathrm{a}$ \\
\hline & & \multicolumn{2}{|c|}{ Carman } & \multicolumn{2}{|c|}{ Barnsley } \\
\hline & $\mathrm{CV}(\%)$ & Number & Yield & Number & Yield \\
\hline \multirow[t]{4}{*}{1979} & $\theta$ & $9.7 \mathrm{a}$ & $3.6 a$ & $5.5 \mathrm{a}$ & $2.1 \mathrm{a}$ \\
\hline & 25 & $11.4 \mathrm{a}$ & $4.2 \mathrm{a}$ & $9.3 \mathrm{a}$ & $3.3 \mathrm{a}$ \\
\hline & 50 & $10.6 \mathrm{a}$ & $4.2 \mathrm{a}$ & $9.0 \mathrm{a}$ & $3.4 \mathrm{a}$ \\
\hline & & & & & \\
\hline \multirow[t]{4}{*}{$\underline{1980}$} & 0 & $25.4 \mathrm{a}$ & $9.2 \mathrm{a}$ & $23.4 a$ & $9.1 \mathrm{a}$ \\
\hline & 25 & $27.7 \mathrm{a}$ & $10.9 \mathrm{a}$ & $28.3 \mathrm{a}$ & $10.8 \mathrm{a}$ \\
\hline & 50 & $25.4 \mathrm{a}$ & $9.3 \mathrm{a}$ & $21.0 \mathrm{a}$ & $8.1 \mathrm{a}$ \\
\hline & 75 & $32.5 \mathrm{a}$ & $12.2 \mathrm{a}$ & $18.5 \mathrm{a}$ & $7.0 \mathrm{a}$ \\
\hline
\end{tabular}

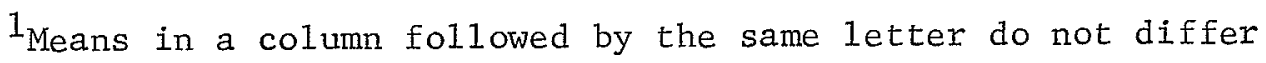
at the $5 \%$ level of significance. 
TABLE 5. Effects of seedtype and in-row variation in spacing on production (number per plot) and yield ( $\mathrm{kg}$ per plot) of tubers in the mid-size grade.

\begin{tabular}{|c|c|c|c|c|c|}
\hline & \multirow[b]{2}{*}{ Seed type } & \multicolumn{2}{|c|}{ Carman } & \multicolumn{2}{|c|}{ Barns1ey } \\
\hline & & Number & Yield & Number & Yie1d \\
\hline \multirow[t]{5}{*}{$\underline{1979}$} & Whole & $128.3 \mathrm{a}^{1}$ & $22.0 \mathrm{a}$ & $142.5 \mathrm{a}$ & $21.7 \mathrm{a}$ \\
\hline & Cut (graded) & $118.3 \mathrm{a}$ & $20.9 \mathrm{a}$ & $142.5 \mathrm{a}$ & $23.7 \mathrm{a}$ \\
\hline & Cut (ungraded) & 130.9 a & $23.0 \mathrm{a}$ & $152.4 \mathrm{a}$ & $25.9 \mathrm{a}$ \\
\hline & & \multicolumn{4}{|c|}{ - } \\
\hline & & \multicolumn{2}{|c|}{ Portage } & \multicolumn{2}{|c|}{ Carman } \\
\hline \multirow[t]{5}{*}{$\underline{1980}$} & Whole & $163.6 \mathrm{a}$ & $31.0 \mathrm{a}$ & $100.6 \mathrm{a}$ & $19.1 \mathrm{a}$ \\
\hline & Cut (graded) & $143.8 \mathrm{~b}$ & $27.6 \mathrm{~b}$ & $96.3 \mathrm{a}$ & $18.8 \mathrm{a}$ \\
\hline & Cut (ungraded) & 120.4 & $22.9 \quad \mathrm{c}$ & $90.4 \mathrm{a}$ & $17.6 \mathrm{a}$ \\
\hline & & \multicolumn{2}{|c|}{ Carman } & \multicolumn{2}{|c|}{ Barnsley } \\
\hline & $\mathrm{CV}(\%)$ & Number & Yield & Number & Yield \\
\hline \multirow[t]{4}{*}{1979} & 0 & $116.5 \mathrm{a}$ & $20.8 \mathrm{a}$ & $137.0 \mathrm{a}$ & $22.6 \mathrm{a}$ \\
\hline & 25 & $128.0 \mathrm{a}$ & $21.7 \mathrm{a}$ & $154.7 \mathrm{a}$ & $25.2 \mathrm{a}$ \\
\hline & 50 & $132.9 \mathrm{a}$ & $23.5 \mathrm{a}$ & $145.7 \mathrm{a}$ & $23.6 \mathrm{a}$ \\
\hline & & \multicolumn{2}{|c|}{ Portage } & \multicolumn{2}{|c|}{ Carman } \\
\hline \multirow[t]{4}{*}{1980} & 0 & $139.8 \mathrm{a}$ & $27.8 \mathrm{a}$ & $109.4 \mathrm{a}$ & $21.2 \mathrm{a}$ \\
\hline & 25 & $158.8 \mathrm{a}$ & $29.7 \mathrm{a}$ & $97.5 \mathrm{a}$ & $18.9 \mathrm{a}$ \\
\hline & 50 & $134.5 \mathrm{a}$ & 25.1 a & $94.4 \mathrm{a}$ & $18.0 \mathrm{a}$ \\
\hline & 75 & $139.1 \mathrm{a}$ & $26.5 \mathrm{a}$ & $82.0 \mathrm{a}$ & $15.9 \mathrm{a}$ \\
\hline
\end{tabular}

$1_{\text {Means in a column followed by the same letter do not differ at }}$ the $5 \%$ level of significance. 
terms of hollow heart, as many authors have found close spacing to reduce hollow heart (Moore and Wheeler, 1928; Edmundson, 1935; Nelson, 1970). Although localized gaps occurred within rows with high CV levels, only slight increases in the percent hollow heart were recorded at higher CV levels (Table 6). Similarly, there appeared to be 1ittle effect of seedtype on hollow heart, except at Portage la Prairie in 1980, where the smallest seedtype resulted in a significantly higher percentage of hollow heart than the larger seedtype (Table 6). In contrast, a slight reduction in hollow heart occurred with decreasing seedpiece mass at Carman in 1979. However, the differences were not significant.

In experiment 1 it appeared that the largest contributing factor to the percent hollow heart in the respective crops was the year in which the crop was grown. Nelson (1970) reported that early planting reduced hollow heart. Although planting dates were earlier in 1980, due to the later emergence relative to 1979, comparison with Nelson (1970) may not be meaningful. Of the two theories for hollow heart discussed earlier, results from experiment 1 favour the one which suggests that hollow heart may be initiated by subjecting potato plants to stress after tuber initiation (Levitt, 1942; Dinkel, 1960; Crumbly et al., 1973). In 1979, tubers were subjected to moisture stress from the time of initiation until harvest time. However, in 1980 moisture conditions were favourable from about the time of tuberization to the time of harvest, resulting in lower percentages of hollow heart. In addition, results from experiment 1 appeared to contradict some aspects of the second theory which suggests that hollow heart is induced by rapid tuber enlargement (Moore and Wheeler, 1928; Nelson and Thoreson, 1974). Although no measurements of tuber bulking rates or tuber enlargement per se were recorded, it appeared 
TABLE 6. Effects of seedtype and in-row variation in spacing on the incidence of hollow heart.

\begin{tabular}{|c|c|c|c|}
\hline & & Carman & Barnsley \\
\hline & $\mathrm{CV}(\%)$ & Hollow heart $(\%)$ & Hollow heart $(\%)$ \\
\hline \multirow[t]{4}{*}{1979} & 0 & $45.3 \mathrm{a}^{1}$ & 29.0 a \\
\hline & 25 & $35.3 \mathrm{a}$ & 37.9 a \\
\hline & 50 & $50.7 \mathrm{a}$ & $41.4 \mathrm{a}$ \\
\hline & & Portage & Carman \\
\hline \multirow[t]{6}{*}{$\underline{1980}$} & 0 & $8 . \dot{3}$ a & $8.5 \mathrm{a}$ \\
\hline & 25 & $7.5 \mathrm{a}$ & $8.1 \mathrm{a}$ \\
\hline & 50 & $12.6 \mathrm{a}$ & $8.4 \mathrm{a}$ \\
\hline & 75 & $5.4 \mathrm{a}$ & $10.8 \mathrm{a}$ \\
\hline & & Carman & Barnsley \\
\hline & Seed type & Hollow heart $(\%)$ & Hollow heart $(\%)$ \\
\hline \multirow[t]{5}{*}{1979} & Whole & 48.1 a & $37.1 \mathrm{a}$ \\
\hline & Cut (graded) & $45.0 \mathrm{a}$ & $37.2 \mathrm{a}$ \\
\hline & Cut (ungraded) & 44.1 a & $37.7 \mathrm{a}$ \\
\hline & & $-\cdots--1--\cdots$ & 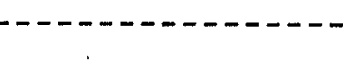 \\
\hline & & Portage & Carman \\
\hline \multirow[t]{3}{*}{1980} & Whole & $4.9 \mathrm{~b}$ & $9.8 \mathrm{a}$ \\
\hline & Cut (graded) & $6.6 \mathrm{~b}$ & $7.7 \mathrm{a}$ \\
\hline & Cut (ungraded) & $13.8 \mathrm{a}$ & $9.8 \mathrm{a}$ \\
\hline
\end{tabular}

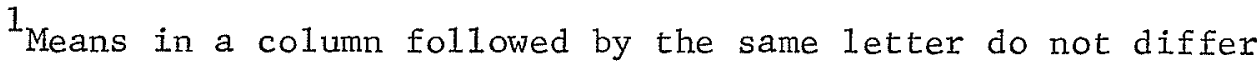
at the $5 \%$ level of significance. 
that tuber enlargement was much more rapid in 1980 . This was reflected in both the greater percentage of over-sized tubers (Table 4) and the relatively fewer unmarketable tubers (Table 2) in 1980. Therefore, in addition to disproving this theory, results from experiment 1 appeared to contradict it. These results also contradicted those reported by Nelson (1979) who observed that hollow heart was reduced when temperatures following tuber initiation were high and rainfall was low. These were the types of conditions which prevailed in 1979.

\section{Experiment 2}

This experiment was conducted in 1980 only. In addition to measurements made in experiment 1 such as tuber production and yield, attempts were made to monitor crop development more closely by conducting mainstem and branch counts. In this experiment, the seedtype-spacing interaction was found to be non-significant for tuber production and yield (Tables $23 a$ and $b$, Appendix).

Reductions in total tuber production and yield were recorded for both decreases in seedpiece mass and increased in-row spacing (Table 7). However, differences were significant in only one instance. The crop grown at the $30.4 \mathrm{~cm}$ spacing produced significantly more tubers than those at the 45.7 and $60.9 \mathrm{~cm}$ spacings.

Although tuber production and yield per plot generally decreased with increased spacing, individual seedtypes displayed different trends. The total tuber production and yield means of individual seedtypes at the three in-row spacings are presented in Figure 11. Seedtype B (cut-graded seed) appeared to be least affected by spacing as there was 1ittle change in total tuber production for the three spacings. Effect of spacing on seedtypes A and C was more marked as both had an approximate $40 \%$ decrease 
TABLE 7. Effects of seedtype and in-row spacing on production (number per plot) and yield ( $\mathrm{kg}$ per plot) of tubers in the marketable and total yield categories: Portage la Prairie, 1980 .

\begin{tabular}{|c|c|c|}
\hline \multirow{2}{*}{ Seedtype } & \multicolumn{2}{|c|}{ Marketable Yield } \\
\hline & Number & Yield \\
\hline Whole & $110.8 \mathrm{a}^{1}$ & $22.7 \mathrm{a}$ \\
\hline Cut (graded) & $96.7 \mathrm{a}$ & $20.2 \mathrm{a}$ \\
\hline Cut (ungraded) & 90.1 a & $18.4 \mathrm{a}$ \\
\hline \multicolumn{3}{|l|}{ Spacing $(\mathrm{cm})$} \\
\hline 30.4 & $113.3 \mathrm{a}$ & $22.3 \mathrm{a}$ \\
\hline 45.7 & $88.4 \mathrm{a}$ & $17.7 \mathrm{a}$ \\
\hline \multirow[t]{2}{*}{60.9} & $95.8 \mathrm{a}$ & $21.4 \mathrm{a}$ \\
\hline & \multicolumn{2}{|c|}{ Total Yield } \\
\hline Seedtype & Number & Yield \\
\hline Whole & $208.1 \mathrm{a}$ & $31.2 \mathrm{a}$ \\
\hline Cut (graded) & $192.6 \mathrm{a}$ & $27.9 \mathrm{a}$ \\
\hline Cut (ungraded) & $191.0 \mathrm{a}$ & $26.0 \mathrm{a}$ \\
\hline \multicolumn{3}{|l|}{ Spacing $(\mathrm{cm})$} \\
\hline 30.4 & 238.8 a & 32.9 a \\
\hline 45.7 & $191.6 \mathrm{~b}$ & $25.5 \mathrm{a}$ \\
\hline 60.9 & $161.3 \mathrm{~b}$ & $26.7 \mathrm{a}$ \\
\hline
\end{tabular}


in total tuber production per plot as the spacing increased from $30.4 \mathrm{~cm}$ to $60.9 \mathrm{~cm}$. The trends observed for tuber production were reflected in the total yield with one exception. The total yield for seedtype $B$ was relatively unchanged at the $30.4 \mathrm{~cm}$ and $60.9 \mathrm{~cm}$ spacings (Fig. 11). However, at the $45.7 \mathrm{~cm}$ spacing, the total yield was approximately $20 \% 1$ ower than at the other two spacings. The total yields for seedtypes $\mathrm{A}$ and $\mathrm{C}$ generally decreased with increased spacing. However, unlike the similarities between these two seedtypes in tuber production, yields from seedtype $\mathrm{C}$ were affected to a much greater degree by increases in spacing. Seedtypes $\mathrm{A}$ and $\mathrm{C}$ had reductions in total yields of approximately $20 \%$ and $35 \%$, respectively (Fig. 11) and support observations by Iritani et al. (1972). Reductions in marketable tuber production and yield were also recorded for decreases in seedpiece mass and increased in-row spacing (Table 7). Although significant differences were not observed, the yield reductions could be of economic significance. Despite the lack of a significant spacing-seedtype interaction, the performances of the individual seedtypes at the three spacings (Fig. 11) may be of practical significance. Production of tubers in the marketable category remained relatively unchanged for seedtype A over all spacings, however, both seedtypes B and C were greatly affected. The effect of spacing on marketable tuber production by seedtype $\mathrm{C}$ was very similar to the spacing effect on its total tuber production, namely a lower production at the wider spacing. No visible trend can be observed with seedtype $B$, as the production of marketable tubers was lower at the $45.7 \mathrm{~cm}$ spacing, relative to the other spacings. Although seedtype B produced the highest marketable yield at the $60.9 \mathrm{~cm}$ spacing (Fig. 11), due to the very low marketable yield at the $45.7 \mathrm{~cm}$ spacing, this seedtype had poor overall performance in this experiment. 


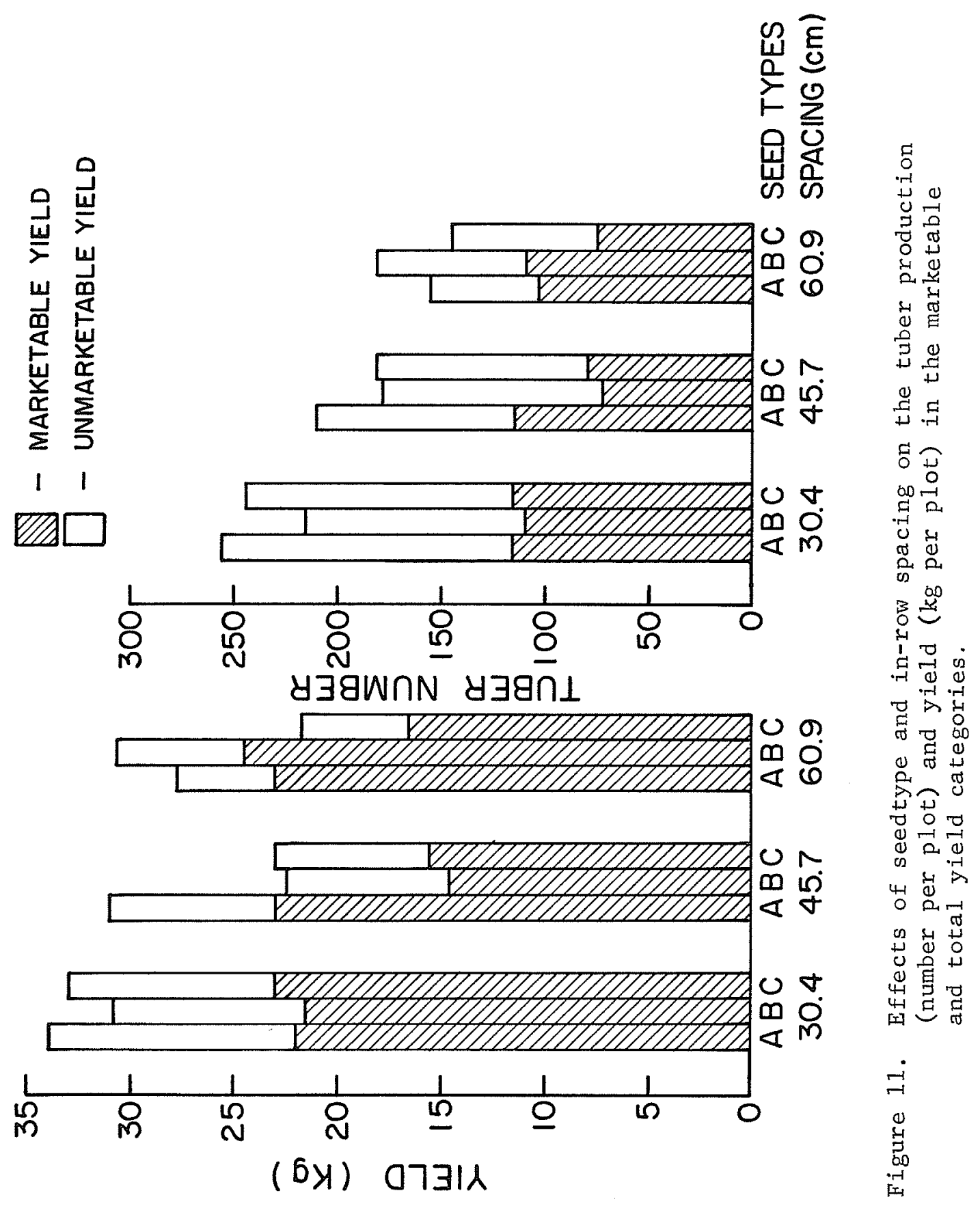


Reduced yield may be due to poor seedpiece performance such as low stem number production per seedpiece. However, this was not the case as the number of mainstems per seedpiece appeared normal relative to seedtypes $A$ and $\mathrm{C}$ (Table 9). In addition, no visual differences occurred between plants grown from seedtype $B$ and plants grown from other seedtypes. Therefore, this particular observation appeared to have occurred for no obvious reason.

The effects of the different seedtypes on the three individual grades are shown in Table 8. No trends were visible in the unmarketable and oversize grades, however, significant differences occurred in the mid-size grade, In this case, tuber production and yield decreased significantly with decreases in seedpiece mass. This would appear to account for the slightly higher marketable yield recorded for the whole seedtype (Table 7).

Tuber production and yield in the unmarketable grade decreased significantly with increased in-row spacing (Table 8). Decreases were also observed for the mid-size grade (not significant at $P=.05$ ), while the production and yield of tubers in the over-size grade generally increased with increased in-row spacing. However, differences were found to be nonsignificant. Therefore, it appeared that there was a slight shift in the weight distribution of the crop with increased spacing. This is demonstrated by the apparent shift from the production of unmarketable tubers to the production of over-sized tubers. In contradiction with Schepers (1975), there appeared to be little net effect of spacing on the mid-size range of the crop, as the changes appeared to be proportional to the change in the total yield (Table 7). This supports observations in experiment 1 and suggests that the proportion of the yield in the mid- 


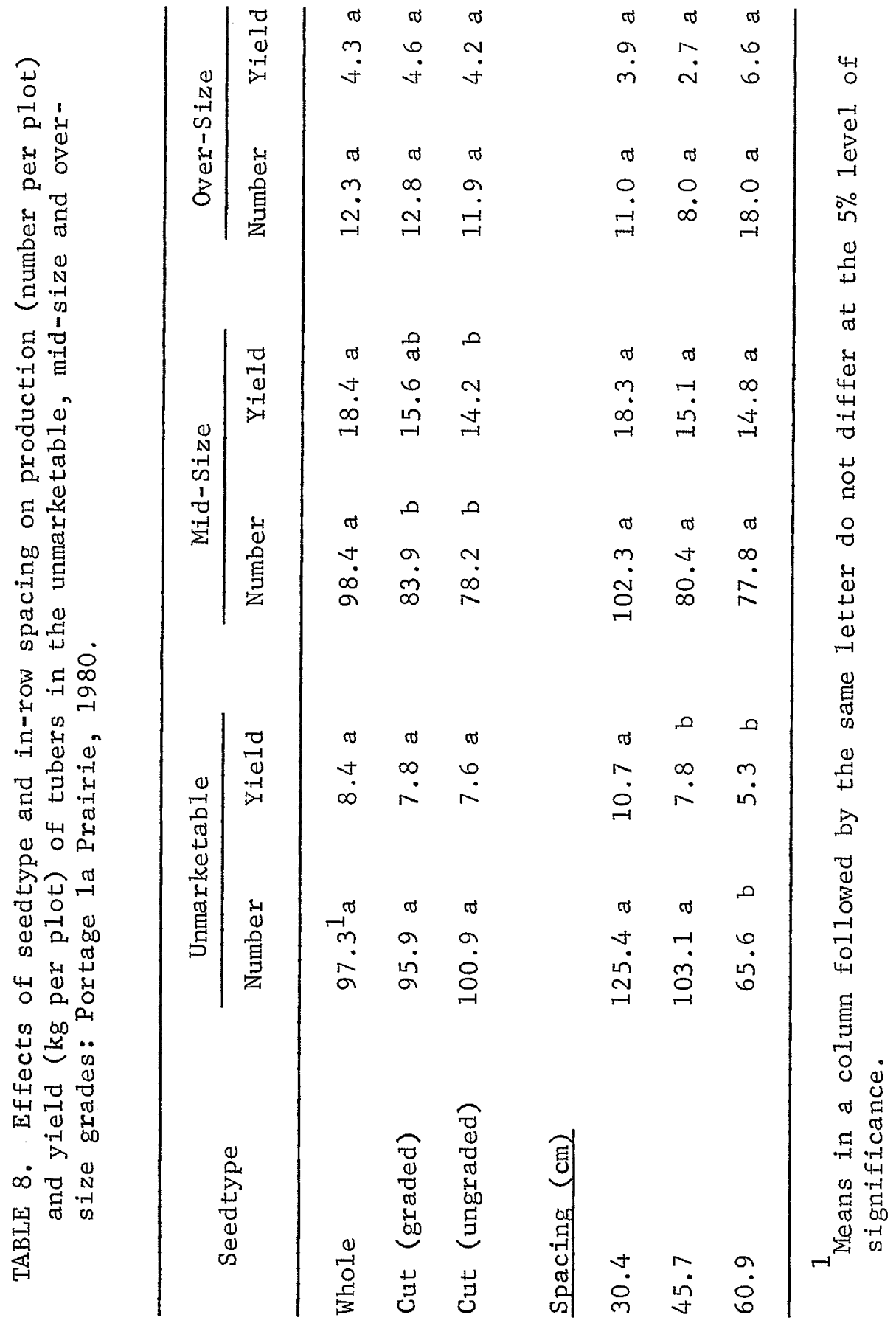


size grade is relatively stable over a range of spatial arrangements.

Timing of mainstem counts has been shown to be important as it is known that stems die and may disappear as a result of competition before crop maturity (Bleasdale, 1965). However, Svensson (1973) found no changes in the population of mainstem as the crop developed. Mainstem counts in this experiment were conducted approximately 2 weeks prior to harvest.

TABLE 9. The mean mass, mean number of mainstems and mean mass per mainstem for three seedtypes: Portage la Prairie, 1980.

\begin{tabular}{lcccc}
\hline \multicolumn{2}{c}{ Seedtype } & & \multicolumn{2}{c}{ Mainstems $^{1}$} \\
\cline { 5 - 6 } Description & Mean mass (g) & & $\begin{array}{c}\text { Number per } \\
\text { seedpiece }\end{array}$ & $\begin{array}{c}\text { Mean mass } \\
\text { per mainstem } \\
(\mathrm{g})\end{array}$ \\
\hline Whole & 77.6 & $3.33 \mathrm{a}^{2}$ & 23.4 \\
Cut (graded) & 67.9 & $2.75 \quad \mathrm{~b}$ & 24.9 \\
Cut (ungraded) & 61.2 & $2.02 \quad \mathrm{c}$ & 30.8 \\
\hline
\end{tabular}

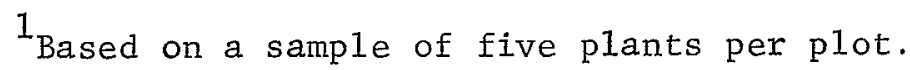

2 Means followed by the same letter do not differ at the $5 \%$ level of significance.

The only factor which significantly $(P=.05)$ affected the mainstem number was the seedtype (Table 9). Mainstem numbers increased significantly with each increase in seedpiece weight and supports observations by Reestman and Dewit (1959), Iritani et al. (1972), Svensson and Naglicka (1975) and Lynch and Rowberry (1977). Density of planting was found to have 1ittle effect on the mainstem number (Fig. 12), supporting the observations of Bleasdale (1965) and Svensson (1973). In a given seedlot of potatoes, the weight of individual seedpieces can vary significantly 
(Figs. 1 and 2), and therefore, the number of mainstems per plant can vary as well. For this reason, it has been suggested that mainstem density may be a more accurate density measurement than seedpiece density (Reestman and Dewit, 1959; Iritani et al., 1972). Although measurements of the tuber production and yield between seedtypes within a given spacing showed no significant differences, increases in spacing were found to have some effect on the crop (Fig. 11). The lowest total tuber production, as we11 as the lowest total yield, occurred at the $60.9 \mathrm{~cm}$ spacing with seedtype $\mathrm{C}$. This was also where the mainstem density was found to be the lowest (Table 10). Therefore, it appeared that yield reductions occur

TABLE 10. The mean mainstem density for three seedtypes and three in-row spacings: Portage la Prairie, 1980.

\begin{tabular}{lccc}
\hline $\begin{array}{c}\text { Spacing } \\
(\mathrm{cm})\end{array}$ & Whole & Cut (graded) & Cut (ungraded) \\
\cline { 2 - 4 } & 11.3 & 7.1 & 6.0 \\
30.4 & 9.3 & 7.1 & 4.1 \\
45.7 & 7.5 & 4.2 & 3.3 \\
60.9 & & & \\
\hline
\end{tabular}

${ }^{1}$ Based on a sample of five plants per plot.

only with marked changes in the number of mainstems per unit area. This supports observations by Scholte (1975) who found yields to decrease at sub-optima1 stem densities. When further comparisons between mainstem densities (Table 10) and yields (Fig. 11) were made, it appeared that there was no linear relationship between stem densities and yield for seedtypes $A$ and $B$. However, decreases in mainstem density for seedtype $\mathrm{C}$ followed the yield reductions more closely. The latter observation 
would support those by Lynch and Rowberry (1977) who found a relationship between decreased stem density and yield. However, comparisons between stem density and yield for seedtypes $A$ and $B$, would indicate that mainstem density may not always be a good indicator ofyield.

The weight of seedpiece per mainstem is presented in Table 9. Generally, the greatest difference occurred between the larger seedtypes (A and B) and seedtype C. Tubers from seedtype C had approximately $20 \%$ to $30 \%$ more weight per mainstem. This contradicts observations by Svensson and Naglicka (1975). No difference in initial plant vigour was observed between seedlings from the different seedtypes.

Although spacing had an effect on the crop, especially in terms of the total tuber production, the effect of the seedtype at a given spacing was apparent in only a few instances (Fig. 11). The ability of the plants to adapt to different densities appeared to arise, at least to an extent, from their ability to increase tuber production per mainstem with increased density. For each seedtype there was a general increase in both total and marketable tubers per mainstem with increased spacing (Table 11). The only obvious exception is seedtype $B$ at the $45.7 \mathrm{~cm}$ spacing where the marked reduction in the number of total and marketable tubers per mainstem, resulted in the lowest overall yield. It appeared that the plants grown from seedtype $C$ can produce as many total and marketable tubers at the 30.4 spacing, as plants from the larger seedtypes (Fig. 11); the compensation by the plants from seedtype $\mathrm{C}$ arising by increased production of tubers per mainstem (Table 11). However, the compensation for reduced mainstem number by the plants from the smallest seedtype appeared to have its limits. Values for tuber production and yield per mainstem for seedtype $\mathrm{C}$ at the $60.9 \mathrm{~cm}$ spacing were among the highest recorded. How- 
TABLE 11. Mean number and mass $(\mathrm{kg})$ of tubers per mainstem for three in-row spacings and three seedtypes: Portage la Prairie, 1980.

\begin{tabular}{|c|c|c|c|c|c|c|}
\hline \multirow{4}{*}{$\begin{array}{l}\text { Spacing } \\
(\mathrm{cm})\end{array}$} & \multicolumn{6}{|c|}{ Marketable Yield per Mainstem ${ }^{1}$} \\
\hline & \multicolumn{3}{|c|}{ Number } & \multicolumn{3}{|c|}{ Mass } \\
\hline & \multicolumn{6}{|c|}{ Seedtype ${ }^{2}$} \\
\hline & $\mathrm{A}$ & B & $\mathrm{C}$ & A & B & C \\
\hline 30.4 & $0.7 b^{3}$ & $0.8 \mathrm{~b}$ & $111 \mathrm{ab}$ & $0.13 \mathrm{~b}^{4}$ & $0.15 \mathrm{~b}$ & $0.22 \mathrm{ab}$ \\
\hline 45.7 & $1.1 \mathrm{ab}$ & $0.7 \mathrm{~b}$ & $1.3 \mathrm{ab}$ & $0.23 \mathrm{ab}$ & $0.14 \mathrm{~b}$ & $0.25 \mathrm{ab}$ \\
\hline \multirow[t]{3}{*}{60.9} & $1.2 \mathrm{ab}$ & $1.8 \mathrm{a}$ & $1.6 \mathrm{ab}$ & $0.26 \mathrm{ab}$ & $0.41 \mathrm{a}$ & $0.34 \mathrm{ab}$ \\
\hline & \multicolumn{6}{|c|}{ Total Yield per Mainstem } \\
\hline & A & B & $\mathrm{C}$ & A & B & C \\
\hline 30.4 & $1.6 \quad \mathrm{c}$ & $1.6 \mathrm{c}$ & $2.3 \mathrm{~b}$ & $0.20 \mathrm{~b}$ & $0.22 \quad b$ & $0.32 \mathrm{ab}$ \\
\hline 45.7 & $2.1 \mathrm{bc}$ & $1.7 \mathrm{bc}$ & $3.0 \mathrm{a}$ & $0.30 \mathrm{ab}$ & $0.22 \mathrm{~b}$ & $0.37 \mathrm{ab}$ \\
\hline 60.9 & $1.8 \mathrm{bc}$ & $3.1 \mathrm{a}$ & $3.0 \mathrm{a}$ & $0.32 \mathrm{ab}$ & $0.51 \mathrm{a}$ & $0.45 \mathrm{ab}$ \\
\hline
\end{tabular}

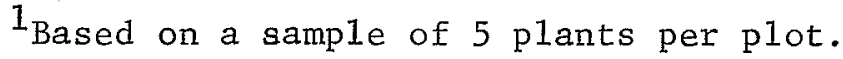

${ }^{2}$ Seedtype $\mathrm{A}=$ whole seed

Seedtype $B=$ cut graded seed

Seedtype $\mathrm{C}=$ cut ungraded seed

3,4 Means recorded for the individual measurements (tuber production and tuber weight) followed by the same letter, do not differ at the $5 \%$ level of significance. 
ever, the total and marketable yields were lower than for other seedtypes at that spacing. Compensation can also be observed for plants grown from seedtype $B$, which had approximately one less mainstem per plant than seedtype A. Due to the increased tuber production per mainstem with plants grown from seedtype B (Table 11), total and marketable yields were similar to those from the largest seedtype. Therefore, it appeared there was an inverse relationship between the mainstem number per unit area and the tuber number per mainstem. These observations are confirmed by Taha (1961) and Lynch and Rowberry (1977). However, in this experiment the relationship did not ensure similar yields for all seedtypes and spacings tested.

Secondary stems arise as branches from the mainstems (Harris, 1978). The number of branches produced by plants from a given seedpiece were most strongly influenced by the spacing (Fig. 12), however, there was a significant seedtype-spacing interaction(Table 23b, Appendix). The number of basal branches increased with each increase in spacing for all seedtypes (Table 12). The relationship between spacing and branching was significantly linear for the whole seedtype only. Plants from seedtype $\mathrm{C}$ produced significantly more branches than those from seedtypes $A$ and $B$ at the $30.4 \mathrm{~cm}$ spacing. However, the situation was reversed at the higher spacings. These results confirm those by Lynch and Rowberry (1977) who reported increased branch development at wider spacing. There was also a relationship between the number of mainstems per plant and the number of branches per mainstem, as plants with fewer mainstems produced more branches per mainstem (Table 13). The numbers of branches per mainstem were influenced most strongly by spacing, as increases were recorded for each increase in spacing. This increase was found to be significantly 


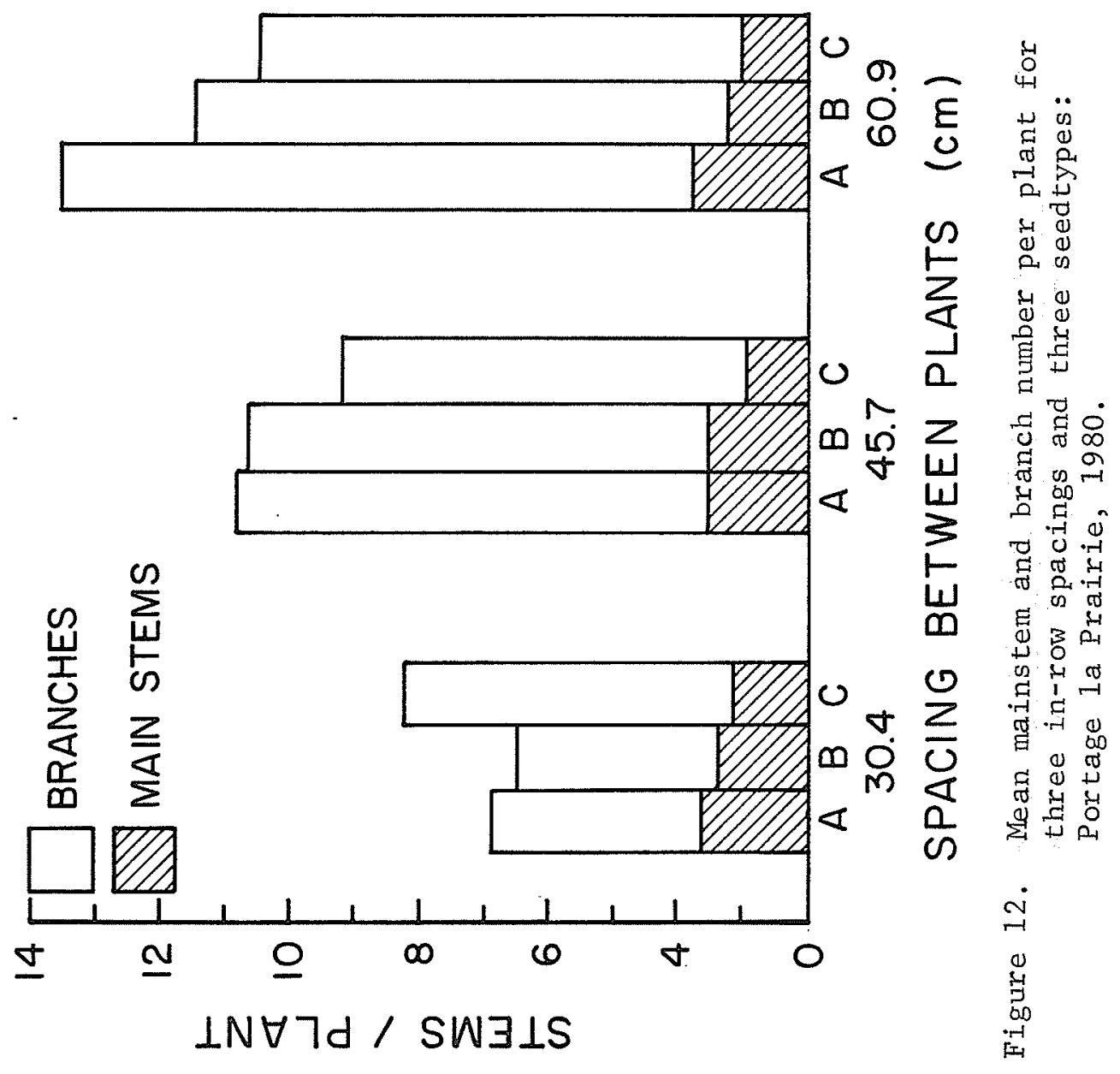


TABLE 12. Mean number of branches ${ }^{1}$ per plant for three in-row spacings and three seedtypes: Portage la Prairie, 1980.

\begin{tabular}{lcccc}
\hline & \multicolumn{4}{c}{ Seedtype } \\
\cline { 2 - 5 }$(\mathrm{cm})$ & Whole & Cut (graded) & Cut (ungraded) \\
\hline 30.4 & $6.5 \mathrm{~cd}^{2}$ & $6.2 \mathrm{~d}$ & $10.13 \mathrm{bcd}$ \\
45.7 & $14.4 \mathrm{ab}$ & $14.1 \mathrm{abc}$ & $12.5 \mathrm{abcd}$ \\
60.9 & $19.5 \mathrm{a}$ & $16.4 \mathrm{ab}$ & $14.9 \mathrm{ab}$ \\
\hline Linear & $*$ & N.S. & N.S. \\
Quadratic & N.S. & N.S. & N.S. \\
\hline
\end{tabular}

${ }^{1}$ Based on a sample of 5 plants per plot.

2 Means followed by the same letter do not differ at the $5 \%$ leve1 of significance.

* Significant at $5 \%$ level of significance.

N.S. Non significant.

linear. Basal branching was also affected by the seedtype, as the plants from seedtype $C$ had significantly more branches per mainstem than plants from seedtypes $A$ and $B$. It appeared that branching increases with reduced intraplant and interplant competition. Therefore, potato crops may be able to maintain a relatively similar leaf area index over a range of seedpiece types and spacings.

The increases in branching followed the same trend as the increases in tuber number per mainstem, discussed earlier. Both allowed a potato plant to compensate for wide in-row spacing. The degree to which the compensation occurs, appeared to be related to the seedpiece weight. Similar observations have been made by several authors (Black, 1957; E1 Saeed, 1963; Scott and Younger, 1972). 
TABLE 13. Mean number of branches per mainstem for three in-row spacings and three seedtypes: Portage la Prairie, 1980.

\begin{tabular}{|c|c|c|}
\hline & \multirow[b]{2}{*}{ Spacing $(\mathrm{cm})$} & Branches \\
\hline & & Number per mainstem \\
\hline & 30.4 & $3.0 \mathrm{~b}^{2}$ \\
\hline & 45.7 & $5.3 \mathrm{a}$ \\
\hline & 60.9 & $6.7 \mathrm{a}$ \\
\hline Linear & & $*$ \\
\hline \multirow[t]{5}{*}{ Quadratic } & & N.S. \\
\hline & Seedtype & \\
\hline & Whole & $4.1 \mathrm{~b}$ \\
\hline & Cut (graded) & $4.5 \mathrm{~b}$ \\
\hline & Gut (ungraded) & $6.4 \mathrm{a}$ \\
\hline \multicolumn{3}{|c|}{$\begin{array}{l}1_{\text {Based on a sample of } 5 \text { plants per plot. }} \\
2_{\text {Means followed by the same letter do not differ at }} \\
\text { the } 5 \% \text { level of significance. } \\
* \text { Significant at } 5 \% \text { level. }\end{array}$} \\
\hline
\end{tabular}


The incidence of hollow varied greatly within experiment 2, as the $\mathrm{CV}$ was $89.6 \%$ (Table 23b, Appendix). There was no significant effect of seedtype on the percent of hollow heart in the crop, although the lowest value was recorded for seedtype A (Table 14). There was, however, a significant effect of spacing on hollow heart. Plants grown at the 30.4 cm spacing produced tubers with significantly lower percentages of hollow heart than those grown at the 45.7 and $60.9 \mathrm{~cm}$ spacings. This supported observations by Moore and Wheeler (1928), Edmundson (1935) and Nelson (1970). Although no measurements per se were recorded, due to the greater
TABLE 14. Mean percent hollow heart for three seedtypes and three in- row spacings: Portage la Prairie, 1980.

\begin{tabular}{lc}
\hline \multicolumn{1}{c}{ Seedtype } & $\begin{array}{c}\text { Hollow heart } \\
(\%)\end{array}$ \\
\hline Whole & $8.3 \mathrm{a}^{1}$ \\
Cut (graded) & $15.7 \mathrm{a}$ \\
Cut (ungraded) & $18.9 \mathrm{a}$ \\
$\quad \begin{array}{c}\text { Spacing } \\
\text { (cm) }\end{array}$ & $3.7 \mathrm{~b}$ \\
\hline $30.4 \quad 19.8 \mathrm{a}$ \\
45.7 & $19.4 \mathrm{a}$ \\
\hline
\end{tabular}

\footnotetext{
$1_{\text {Means followed by the same letter }}$ do not differ at the $5 \%$ level of significance.
}

production of over-sized tubers and the relatively fewer unmarketable 
tubers (Table 8), it appeared that tuber enlargement would be greater at the wider spacings. Such observations would support the theory that hollow heart is induced by rapid tuber enlargement (Moore and wheeler, 1928; Nelson and Thoreson, 1974). 


\section{GENERAL DISCUSSION}

Irregular seedpiece spacing appeared to have no statistically significant effect on yield. The remarkable tolerance of potato plants to changes in spatial arrangement was demonstrated in experiment 2. Measurements of mainstems and branches allowed closer observation of the ability of potato plants to adapt to different levels of intra- and inter-plant competition. Although these measurements were not made in experiment 1 , differences in tuber production and yield between treatments, locations and years, gave additional insight into the adaptability of potato plants. Based on the results presented in the previous discussion and a certain amount of speculation, it appears that there are several factors which dictate the effect of irregular plant stands on yield.

Before any further discussion, it should be noted that in addition to growing these potatoes (cv Netted Gem) for processing, they also must be grown as seed. Production of small unmarketable tubers is undesirable in a processing crop, while production of over-sized tubers is encouraged. However, when this cultivar is grown for seed purposes, a high yielding crop consisting of a large percentage of small tubers is desirable. Therefore, it appears that the crop in 1979 would have been better suited for seed purposes than the crop in $198^{\circ}$ (Fig. 8).

It has been mentioned that the primal plant unit is difficult to define with potatoes, as seedpieces have more than one growing point (Bleasdale, 1965). As the number of growing points differed with seedpieces of different weights (Table 9) and the condition of the seedpiece 
(Wright and Peacock, 1934; Toosey, 1963), spacing per se may be a poor indicator of final yield. An example of this was observed in experiment 2, where dramatic changes in plant spacing resulted in relatively sma1ler changes in yield (Table 7). It appears that the outcome of a crop is influenced not only by seedpiece spacing, but also by seedpiece type and condition and the environmental conditions (especially moisture) prevailing throughout the growing season. A predictable tuber population is, therefore, difficult to achieve as these factors may interact differently in different years. The ability of potato plants to overcome the complex interrelationships of such factors, including irregular spacing, appears to arise from their ability to adapt in terms of their developments. With the understanding that the relative contribution by any one of these factors may change from one year to the next, an attempt will be made to discuss each separately.

Many studies have been conducted using different seedpiece sizes (E1 Saeed, 1963; Iritani et al., 1972; Painter et al., 1977). There are conflicting results on whether or not there were advantages to using large seedpieces. Interpretation of the results from experiments 1 and 2 and of the differences in plant development observed in experiment 2, indicated that dry matter production of plants from large and small seedpieces can converge in some instances. Whether or not this was due to higher relative growth rates of stems from smaller seedpieces (Svensson and Naglicka, 1975) or less suppression of photosynthesis by small seedpieces (Mush, 1962), cannot be determined from these experiments. In 1979, yields from smaller seedpieces were slightly higher than those from large seedpieces, however, the situation was reversed in 1980 . Several authors have suggested that potentially poor performance by 
plants from large seedpieces is due to the high intra-plant competition (Boyd and Lesse1s, 1954; Reestman and Dewit, 1959; Scott and Younger, 1972). Higher intra-plant competition could have been expected for plants grown from seedtype A, as they had a higher tuber set relative to plants grown from smaller seedpieces (Fig. 7).

In addition, it could be suggested that this higher intra-plant competition (clumping) was the reason for the significantly lower marketable yields recorded for seedtype A at Barnsley in 1979 (Table 1). However, other evidence would indicate that clumping may not be a major problem in plants grown from large seedpieces. For example, in experiment 1 (1980), yields were found to be higher (significant at $P=0.05$ in some instances) for the larger seedtypes (Table 1 ). In addition, results from experiment 2 showed that yields from seedtype A were similar to those from seedtype $\mathrm{C}$ at the $30.4 \mathrm{~cm}$ spacing (Fig. 11). In this case, tuber production was equal for both seedtypes. Assuming that intra-plant competition is based on clumping of tubers, no comparison can be made in terms of yield reductions due to intra-plant competition. It appears that the size of seedpiece is not the sole determining factor to tuber set. For example, the tuber set for seedtype $\mathrm{C}$ was much higher in 1979 than the tuber set for seedtype A in 1980 (Fig. 7). Therefore, it could be suggested that yield reductions due to high intra-plant competition are not exclusive to plants grown from large seedpieces.

Observation of compensatory growth by plants from smaller seedtypes may help explain the relatively higher efficiency of these seedtypes which was observed in some instances. At the $30.4 \mathrm{~cm}$ spacing, plants grown from seedtype C produced more branches per plant (Table 12) and 
more tubers per mainstem (Table 11) than plants grown from seedtype A. It could be speculated that at an even closer spacing, plants from seedtype $\mathrm{C}$ would have had less compensatory growth due to increased interplant competition. High inter-plant competition may be more detrimental in terms of marketable yield to plants grown from larger seedpieces, due to their relatively higher stem number. This may have been the reason for the generally superior performance of small seedpieces observed in 1979 (Fig. 8)。 However, there appears to be a point where the compensation by plants from small seedpieces cannot result in equal yields to plants from large seedpieces. For example, seedtype A outyielded seedtype $\mathrm{C}$ at the $45.7 \mathrm{~cm}$ and $60.9 \mathrm{~cm}$ spacings in experiment 2 (Fig. 11). It could be suggested that due to their relatively higher stem number, plants from large seedpieces are better adapted to decreased inter-plant competition. This was demonstrated by the higher branch production (Table 12), at the widest spacing, by plants grown from the whole seedpieces. This may also have been the reason for the better performance by larger seedtypes in 1980 (Fig. 8). In conclusion, it appears that the performance of a given seedtype is determined by its ability to adapt to the inter-plant competition to which it is subjected. While plants from small seedtypes appeared to be better adapted for situations of high inter-plant competition, plants from large seedpieces were superior when inter-plant competition was 1 ow.

Since both intra- and inter-plant competition is based to ancextent on the tuber set, factors which affect the tuber set may also affect seedpiece performance. The degree of dormancy and apical dominance has been found to influence mainstem density (Iritani et al., 1968; Bogucki and Nelson, 1980), which has been found to affect tuber production 
(Harris, 1978). It was observed that seedcutting machines produced seedpieces of varying weights (Figs. 1c and 2c). Therefore, in a given seedlot of potatoes, mainstem production may vary significantly between seedpieces, as it was found that mainstem production was related to seedpiece mass. (Table 9). Clumping of stems, and subsequently of tubers, may be especially serious when planters produce a high percentage of doubles.

The effects of spacing (experiment 2) and years (experiment 1) on the relative performances of the different seedtypes, appeared to be somewhat similar. Results from experiment 2 indicated that compensatory growth by plants grown from seedtype $\mathrm{C}$ ensured similar yields to seedtypes $\mathrm{A}$ and $\mathrm{B}$ at the $30.4 \mathrm{~cm}$ spacing. However, for the conditions at that location in that year, a 45.7 and $60.9 \mathrm{~cm}$ spacing appeared to be too wide for seedtype C. Several observations indicated that under environmental conditions in which experiment 1 was conducted, the $45.7 \mathrm{~cm}$ mean spacing was too close in 1979, yet relatively better suited to conditions in 1980. Firstly, the yield of unmarketable tubers was markedly higher in 1979 (Fig. 7). This appeared to be due to the high tuber set coupled with the inability of the moisture stressed plants to bulk them. Also, the relative performances of the different seedtypes were generally reversed in the two years (discussed earlier). From such observations, it could be suggested that year-spacing interactions could occur. Coupled with the other factors which have been found to influence tuber set, it is clear that an optimum tuber population for a given year is difficult to achieve.

Based on the results from experiment 1, it could be suggested that the effects of irregular spacing may differ in different years. Increasing 
CV levels had no visible effect in 1979 (Fig. 10). Although irregular spacing resulted in no visible trend at Portage in 1980, decreases in total and marketable yield were recorded for each increase in CV level at Carman. It has been suggested that the effects of irregular spacing are more marked at lower plant populations (Davies, 1954). Jarvis et al. (1976) indicated that the effects of irregular spacing are more serious when the plant population is below that needed for optimal marketable yields. As was mentioned earlier, it appeared that the $45.7 \mathrm{~cm}$ mean spacing was too narrow. for the conditions in 1979, however, better suited to conditions in 1980 . It could be suggested that the crop in 1980 was somewhat more predisposed to the effects of irregular spacing than the crop in 1979. This wolld support the observations by Jarvis et al. (1976)

The more severe effects of irregular seedpiece placement, at a suboptimal spacing, may have been a result of yield reductions in areas of the row where large gaps occurred. Compensatory growth by plants associated with large gaps, may not have been enough to compensate yield. It has been indicated earlier that there is a limit to compensatory growth. As it is difficult to predict a proper spacing for a given year, it could be suggested that the use of large seedpieces would reduce yield losses due to irregular spacing. This is due to the higher potential for compensatory growth observed by plants grown from large seedpieces.

Schepers (1975) reported that irregular spacing caused greater yield reductions when the crop was harvested immaturely. This may be important in seed production in which case the crop is usually dessicated and harvested somewhat earlier than a processing crop, It could be suggested that in the production of potatoes which are to be harvested earlier 
(seed potatoes or early table potatoes), spacing should be reduced, in order to decrease the potential yield reductions caused by irregular spacing.

As the total and marketable yields in a given year appeared to be a function of the presence or absence of plant stresses, much of the previous discussion may apply to the incidence of hollow heart. The incidence of hollow heart was much lower in 1980 than in 1979 (Table 6); plant stresses appeared to be greater in the latter year. From results of experiment 1 , in addition to observations by several workers (Levitt, 1942; Dinke1, 1960; Crumbly et al., 1973), it appeared that any combination of factors which resulted in plant stresses increased the percent hollow heart in a crop. Significant year-hollow heart interactions have been found (Nelson, 1970; Nelson and Thoreson, 1974).

From the results of experiment 2, it appeared that hollow heart can be greatly reduced with close spacing. Higher percentages of hollow heart at the wider spacing would indicate that rapid tuber enlargement may be the cause of the disorder. It would appear initially that arguments for the causes of hollow heart differ for the two experiments. However, this may not be the case.

It has been suggested that hollow heart may be a result of the relocalization or shifting of calcium within the tuber (Arteca et al., 1980). The authors suggested that this was due to moisture stress, in which case the plants appeared to draw upon tubers as a source of moisture and nourishment. This theory may explain observations of starch hydrolysis in tubers under moisture stress (Crumbly et al., 1973), and may also explain the differences in the percent hollow heart observed in 1979 and 1980. It could be speculated that the apparently higher 
plant stresses in 1979 could have resulted in relocalization of calcium, which in turn resulted in hollow heart. Relocalization of elements may also have been the reason for higher percentages of hollow heart at the wider spacings in experiment 2. Plants which were grown at the wider spacings appeared to have had a larger canopy (Fig. 12). This could leave such plants more susceptible to moisture stresses. 
SUMMARY AND CONCLUSIONS

Irregular spacing in potato fields in Manitoba is due primarily to the mechanical design of potato planters. Although some planters were slightly better than others, inaccurate seedpiece placement was observed with al1 planters surveyed. No differences were observed in the accuracy of cup-type planters over pick-type planters.

The accuracy of potato planters which are presently in use, was improved when uniform seedpieces were planted. Since seed cutting machines produce seedpieces of non-uniform size, hand-grading is needed to improve the sample. Seedlots of whole seed were also found to be nonuniform in size and grading advantageous. Improved precision of the pick-type feeding mechanisms was observed when seedpieces ofunniform size were planted.

The use of both whole seedpieces (75-77 g) and large cut seedpieces $(67 \mathrm{~g})$, which were of uniform size, resulted in significant yield advantages in some instances. When an accurate $45.7 \mathrm{~cm}$ in-row spacing was used, the use of smaller seedpieces (59-61 g) resulted in lower yields. Although the use of larger seedpieces did not appear to be warranted at a $30.4 \mathrm{~cm}$ spacing, very few growers in Manitoba use an in-row spacing of less than $45 \mathrm{~cm}$.

Seedpiece placement in Manitoba potato fields has been found to be inaccurate resulting in large gaps within the row. Under such conditions, larger seedpieces were found to produce higher yielding crops. Plants grown from whole or large cut seedpieces appeared to be more able to com- 
pensate for gaps in the row than plants grown from smaller seedpieces.

From these observations it is recommended that large seedpieces of about $70 \mathrm{~g}$ should be used in commercial potato production. If seedpieces are cut, hand-grading is necessary. Although whole and cut seedpieces of similar weights were found to produce crops similar in yield, cut seedpieces may be more susceptible to seedpiece decay and cutting can result in viral and bacterial disease spreading.

Inaccurate placement of seedpieces caused reductions in both total and marketable yields. Yield increases cannot be expected with irregular spacing. Large gaps between plants were observed when spacing was irregular, however, no increases in the production of over-size tubers appeared to occur from plants associated with such gaps.

A complex inter-relationship appeared to exist between environmental conditions (especially moisture) and the mean spacing. Yield reductions due to irregular spacing appeared to be greater when the mean spacing was below that needed for optimum yield.

In some instances, irregular spacing resulted in no yield reductions. It appeared that this was due to the ability of potato plants to adapt, in terms of their development, to various spatial arrangements. Plants growing adjacent to large gaps increased branch and tuber production. However, there appeared to be Iimits to this compensatory growth which do not ensure similar yields relative to even plant stands. For this reason it is apparent that in order to maximize yield, the accuracy of potato planters must be improved.

Although no significant $(P=.05)$ effect of irregular in-row spacing on yield was observed in this study, reductions in yield could be of economic significance in some instances. In addition, it was observed 
that yield reductions were recorded at the first increment of irregular spacing $(C V=25 \%)$ in some cases. Therefore, yield reductions due to irregular spacing would be eliminated if the accuracy of potato planters were improved so that the $\mathrm{CV}$ of in-row spacing is not greater than $25 \%$. Some variation could always be expected due to the apparent rolling of seedpieces in the furrow and the incidence of doubles. However, it is being suggested that the adaptability of potato plants would compensate for this small amount of variation in spacing.

Increased accuracy of potato planters may ultimately reduce plant stresses, as large amounts of compensatory growth (either to increase or to restrict dry matter production) would not occur. This would reduce the incidence of hollow heart which appears to be a stress related phenomenon. 


\section{RECOMMENDATIONS}

The following recommendations are made on the basis of this study:

1) Whole seedpieces should be used in the production of potato crops. This will result in more consistent yields and less disease.

2) If cut seed is to be used, seed cutting machines should be adjusted to produce seedpieces with a mean mass of $70 \mathrm{~g}$. Seedlots should be graded in order to reduce the standard deviation of seedpiece mass to less than $10 \mathrm{~g}$.

3) Potential yield losses due to irregular in-row spacing would be eliminated if the distribution of seedpieces in the row had a CV of less than $25 \%$. This could only be achieved with planter redesign.

4) The mean spacing needed for optimum yield appears to be greatly influenced by the environment. Further research is needed to estimate the optimum mean spacing for growing Netted Gem potatoes in Manitoba.

5) All spacing trials should be hand planted because regular seedpiece spacing cannot be expected from mechanical planters.

6) This study was conducted with one cultivar. The reaction to irregular spacing by other cultivars, may differ from those observed here. 


\section{REFERENCES}

ANDREW, WM.T. 1968. Plant stands in potato fields. Proc. Alberta Potato Commission, Edmonton, Alberta, 4-7.

ARTECA, R.N., POOVAIAH, B.W. and HILLER, L.K. 1980. E1ectron microprobe and neutron activation analysis for the determination of elemental distribution in hollow heart potato tubers. Am. Potato J. 6: 241-248.

BATES, G.H. 1935. A study of the factors influencing size of potato tubers. J. Agric. Sci. 25: 297-313.

BLACK, J.H. 1957. In Ivins, J.D. and Milthorpe, F.L. (êds.). The Growth of the Potato. pp. 267. London: Butterworths.

BLEASDALE, J.K.A. 1965. Relationship between set characters and yield in maincrop potatoes. J. Agric. Sci. 64: 361-365.

BOGUCKI, S. and NELSON, D.C. 1980. Length of dormancy and sprouting characteristics of ten potato cultivars. Am. Potato J. 57: 151-157.

BOYD, D.A. and LESSELS, W.J. 1954. The effect of seed rate on the yield of potatoes. J. of Agric. Sci. 44: 465-476.

BREMNER, P.M. and EL SAEED, A.K. 1963. The significance of seed size and spacing. In Ivins, J.D. and Milthorpe, F.I. (eds.). The Growth of the Potato. pp. 267-280. London: Butterworths.

CRUMBLY, I.J., NELSON, D.C. and DYSEN, M.E. 1973. Relationships of hollow heart in Irish potatoes to carbohydrate reabsorption and growth rates of tubers. Am. Potato J. 50: 266-274.

DAVIES, G.J. 1954. Potato Spacing Experiments 1950-52. Report 38. N.I.A.E., Silsoe, England.

DINKEE, D.H. 1960. A study of factors influencing the development of hollow heart in Irish Cobbler potatoes. Abstract from Ph.D. Thesis, University of Minnesota, St. Pau1, Minn.

EDMUNDSON, W.E. 1935. Distance of planting Rural New York No. 2 and Triumph potatoes as affecting yield, hollow heart, growth cracks and second growth tubers. U.S. Dept. of Agric. Circ. No. 338.

EL SAEED, A.K. 1963. In Ivins, J.D. and Milthorpe, F.L. (eds.). The Growth of the Potato. pp. 268-273. London: Butterworths. 
EMILSSON, B. 1949. Physiological mechanisms concerned in sprout growth. In Ivins, J.D. and Milthorpe, F.L. (eds.). The Growth of the Potato. pp. 45-62. London: Butterworths.

HARRIS, P.M. 1978. In Harris, P.M. (ed.). The Potato Crop. pp. 196239. New York: Chapman and Ha11.

HAUGHDAL, S. 1957. In Ivins, J.D. and Milthorpe, F.I. (eds.). The Growth of the Potato. pp. 271. London: Butterworths.

HIRST, J.M., HIDE, G.A., STEDMAN, O.J. and GRIFFITH, R.L. 1973. Yield compensation in gappy potato crops and methods to measure effects of fungi pathogenic on seed tubers. Ann. Applied Biology 73: 143-150.

IRITANI, W.M. 1968. The effect of storage temperature and source on productivity of Russet Burbank seed. Am. Potato J. 45: 322-326.

IRITANI, W.M., THORNTON, R., WELLER, L. and O'LEARY, G. 1972. Relationships of seed size, spacing, stem number to yield of Russet Burbank potatoes. Am. Potato J. 49: 463-469.

JAMES, W.C., LAWRENCE, C.H. and SHIH, C.S. 1973. Yield losses due to missing plants in potato crops. Am. Potato J。 50: 345-352.

JAMES, W.C., BRADLEY, R.H.E., SMITH, C.S. and WONG, S.T. 1975. Misses in potato crops in New Brunswick in 1973; their extent distribution and cause. Am. Potato J. $\underline{52}$ : 83-87.

JARVIS, R.H. and SHOTTON, F.E. 1971. Population studies with King Edward potatoes. Experimental Husbandry 20: 12-29.

JARVIS, R.H. and PALMER, G.M. 1973. Effect of type of planter on the growth and yield of maincrop potatoes. Experimental Husbandry 24: 29-36.

JARVIS, R.H., ROGERS-LEWIS, D.S. and BRAY, W.E. 1976. Effect of irregular set spacing on maincrop potatoes. Experimental Husbandry 30: $28-41$.

KRIJTHE, N. 1946. In Ivins, J.D. and Milthorpe, F.L. (eds.). The Growth of the Potato. pp. 4-5. London: Butterworths.

LEVITT, J. 1942. A histological study of hollow heart of potatoes. Am. Potato J. 19: 134-143.

LYNCH, D.R. and ROWBERRY, R.G. 1977. Population density studies with Russet Burbank. II. The effect of fertilization and plant density on growth, development and yield. Am. Potato J. 54: 57-71.

MISENER, G.C. 1979. Evaluation of cup and pick type potato planters. C.S.A.E. Univ. of New Brunswick. Paper No. ATL 79-9.

MOORE, H.C. and WHEELER, E.J. 1928. Further studies of potato hollow heart. Mich. Agr. Exp. Sta. Quant. Bull. 11: 20-24. 
MUSH, N.H. 1962. Interaction of heterotrophic and autotrophic nutrition in potato ontogenesis. Translated from Fiziologiya Rastenii 8: 183-187.

NELSON, D.C. 1970. Effect of planting date, spacing and potassium on hollow heart in Norgold Russet potatoes. Am. Potato J. 47: 130-135.

NELSON, D.C. and THORESON, M.C. 1974. Effect of root pruning and sub-lethal rates of dinoseb on hollow heart of potatoes. Am. Potato $\mathrm{J}$. 51: $132-138$.

NELSON, D.C., JONES, D.A. and THORESON, M.C. 1979. Relationships between weather, plant spacing and the incidence of hollow heart in Norgold Russet potatoes. Am. Potato J. ㅌ: 581-586.

OHMS, R.E. and CROSS, V.S. 1967. Better potato stands. Idaho Agricultural Extension Bul1. 486.

PAINTER, C.G., OHMS, R.E. and WALZ, A. 1977. Effect of planting date, seed spacing, nitrogen rate and harvest date on yield and quality of potatoes in southwestern Idaho. Idaho Agricultural Extension Bull. 571: $1-15$.

PALMER, G.M. 1976. Effect of close-graded seed on the yield of maincrop potatoes. Experimental Husbandry 30: 18-23.

P.A.M.I. Evaluation Report No. E1178A, 1978. Portage la Prairie, Manitoba.

PASCAL, J.A., ROBERTSON, T.P. and LANGLEY, A. 1977. Yield effects of regularly and irregularly spaced potato tubers. Experimental Husbandry 32: $25-33$.

REESTMAN, A.J. and DE WIT, C.T. 1959. Yield and size distribution of potatoes as influenced by seed rate. Neth. J. Agric. Sci. I: 257-268.

ROER, L. 1955. Forsok med Forskjellige Settepotetstorrelsor og med ulike Settcavstander. Forsten. Fors. Landbr. 6: 17-41.

SADLER, E.M. 1961. IN Ivins, J.D. and Milthorpe, F.L. (eds.). The Growth of the Potato. pp. 4-14. London: Butterworths.

SALISBURY, F.B. and ROSS, C.W. 1969. In Salisbury, F.B. and Ross, C.W. (eds.). Plant Physiology. pp. 452-456. Belmont: Wadsworth.

SCOTT, R.K. and YOUNGER, A. 1972. Potato agronomy in a changing industry. Outlook on Agriculture 7: 3-9.

SCHEPERS, A. 1975. The effect of irregular spacing on the yield and grade of seed potatoes. Bedrijfsontwikkeling 6: 1019-1021.

SCHIPPERS, P.A. 1956. In Ivins, J.D. and Milthorpe, F.I. (eds.). The Growth of the Potato. pp. 34. London: Butterworths.

SCHOLTE, K. 1975. De invloed van onregelmatige plantafstanden in de rij op de opbrengst en de sortering van pootaardappelen. Bedrijfsontwikkeling 6: $731-735$. 
SHOTTON, F.E. 1976. An evaluation of different types of potato planters. Experimenta1 Husbandry $\underline{30}$ : 1-17.

STOREY, T.S. and BARRY, P. 1976. Effect of drill width and plant population on yield of maincrop potatoes. Irish J. Agric. Research 15: $331-339$.

SVENSSON, B. 1973. Development of potato stands in relation to density. Swedish J. Agric. Research 3: 3-12.

SVENSSON, B. and NAGLICKA, I. 1975. Development of potato stands in relation to stand density. Potato Research 18: 105-108.

TAHA, MAA. 1961. In Ivins, J.D. and Milthorpe, F.L. (eds.). The Growth of the Potato. pp. 267-278. London: Butterworths.

TOOSEY, R.D. 1963. The influence of sprout development at planting on subsequent growth and yield. In Ivins, J.D. and Milthorpe, F.I. (eds.). The Growth of the Potato. pp. 79-93. London: Butterworths.

WRIGHT, R.C. and PEACOCK, W.M. 1934. In Ivins, J.D. and Milthorpe, F.L. (eds.). The Growth of the Potato. pp. 34. London: Butterworths.

YAMAGUCHI, M., TIMM, H. and SPURR, A.R. 1964. Effect of soil temperature on growth and nutrition of potato plants and tuberization, composition and periderm structure of tubers. Proc. Amer. Soc. Hort. Sci. 84: $412-423$. 
APPENDIX 
TABLE 15. Meteorological information: 1979.

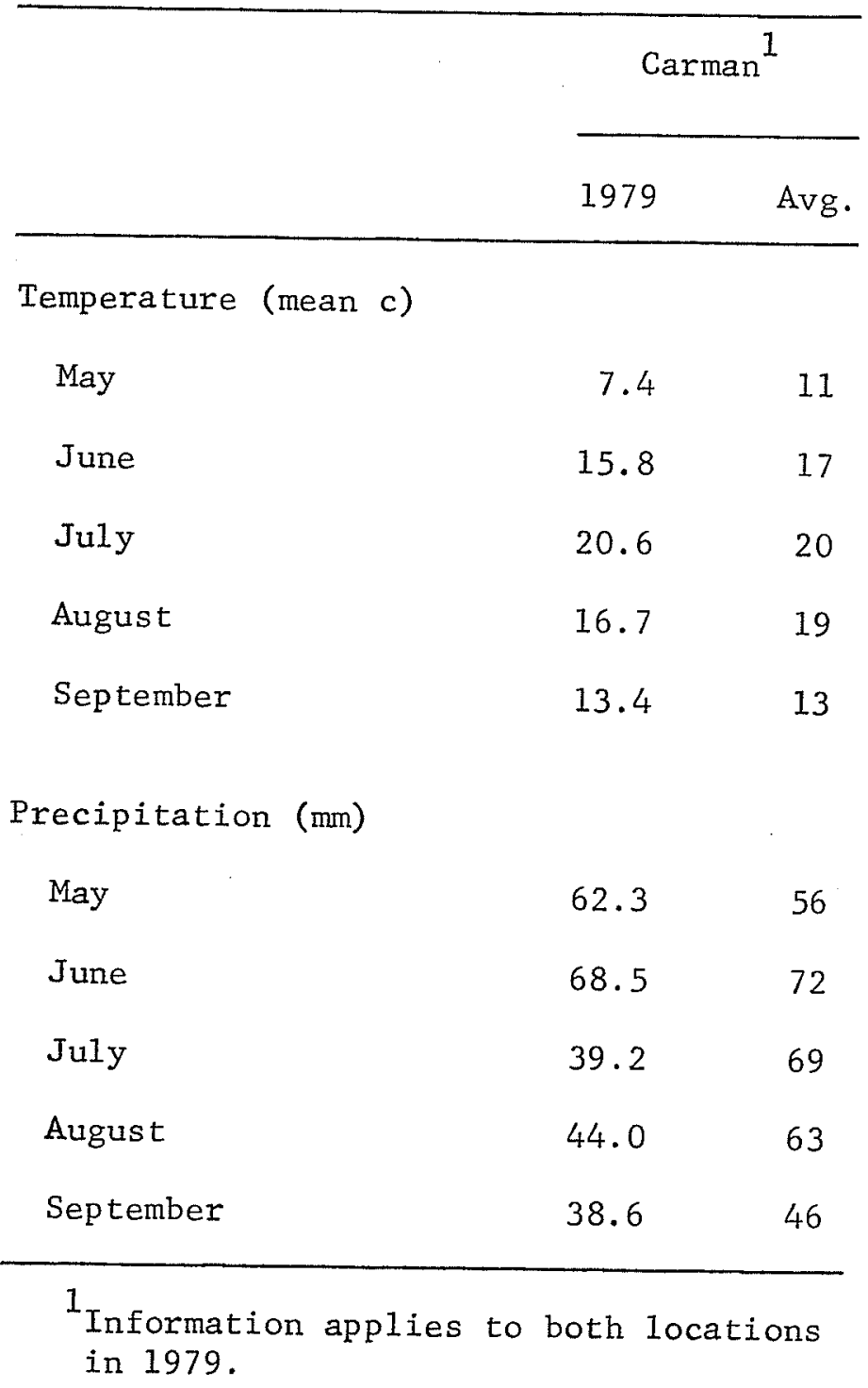


TABLE 16. Meteorological information: 1980.

\begin{tabular}{|c|c|c|c|c|}
\hline & \multicolumn{2}{|c|}{ Carman } & \multicolumn{2}{|c|}{ Portage } \\
\hline & 1980 & Avg. & 1980 & Avg. \\
\hline \multicolumn{5}{|c|}{ Temperature (mean $\mathrm{C}$ ) } \\
\hline May & 15.8 & 11.0 & 17.6 & 10.8 \\
\hline June & 16.5 & 17.0 & 17.3 & 16.8 \\
\hline July & 20.5 & 20.0 & 20.6 & 19.6 \\
\hline August & 16.7 & 19.0 & 16.7 & 18.4 \\
\hline September & 11.8 & 13.0 & 13.3 & 12.4 \\
\hline \multicolumn{5}{|c|}{ Precipitation (mm) } \\
\hline May & 8.9 & 56.0 & 0.0 & 64.0 \\
\hline June & 66.3 & 72.0 & 36.3 & 81.0 \\
\hline July & 41.4 & 69.0 & 0.0 & 78.0 \\
\hline August & 52.3 & 63.0 & 186.7 & 80.0 \\
\hline September & 64.0 & 46.0 & 55.8 & 52.0 \\
\hline
\end{tabular}


TABLE 17. Planting dates, fertilizer application rates and harvest dates for all locations in 1979 and 1980.

\begin{tabular}{|c|c|c|c|c|}
\hline Year & Location & Planting date & $\begin{array}{c}\text { Fertilizer application } \\
\text { and rate }\end{array}$ & Harvest date \\
\hline 1979 & Carman & June 4 & $\begin{array}{l}224 \mathrm{~kg} / \mathrm{ha} \\
24-16-10 \\
\text { spring broadcast }\end{array}$ & October 5 \\
\hline 1979 & Barns ley & June 1 & $\begin{array}{l}224 \mathrm{~kg} / \mathrm{ha} \\
19-13-15 \\
\text { spring broadcast } \\
168 \mathrm{~kg} / \mathrm{ha} \\
19-13-15 \\
\text { side banded } \\
\text { with planter }\end{array}$ & September 30 \\
\hline 1980 & Carman & May 14 & $\begin{array}{l}448 \mathrm{~kg} / \mathrm{ha} \\
19.5-16.5-19.5-3.6 \\
\text { spring broadcast } \\
39 \mathrm{~kg} / \mathrm{ha} \\
\text { anhydrous ammonia } \\
\text { side banded after } \\
\text { crop emergence }\end{array}$ & September 26 \\
\hline 1980 & Portage & May 26 & $\begin{array}{l}67 \mathrm{~kg} / \mathrm{ha} \\
\text { anhydrous ammonia } \\
\text { fal1 applied } \\
392 \mathrm{~kg} / \mathrm{ha} \\
9.7-26-25 \\
\text { side banded } \\
\text { with planter }\end{array}$ & $\begin{array}{l}\text { Experiment } 1 \\
\text { September } 29 \\
\text { Experiment } 2 \\
\text { September } 30\end{array}$ \\
\hline
\end{tabular}









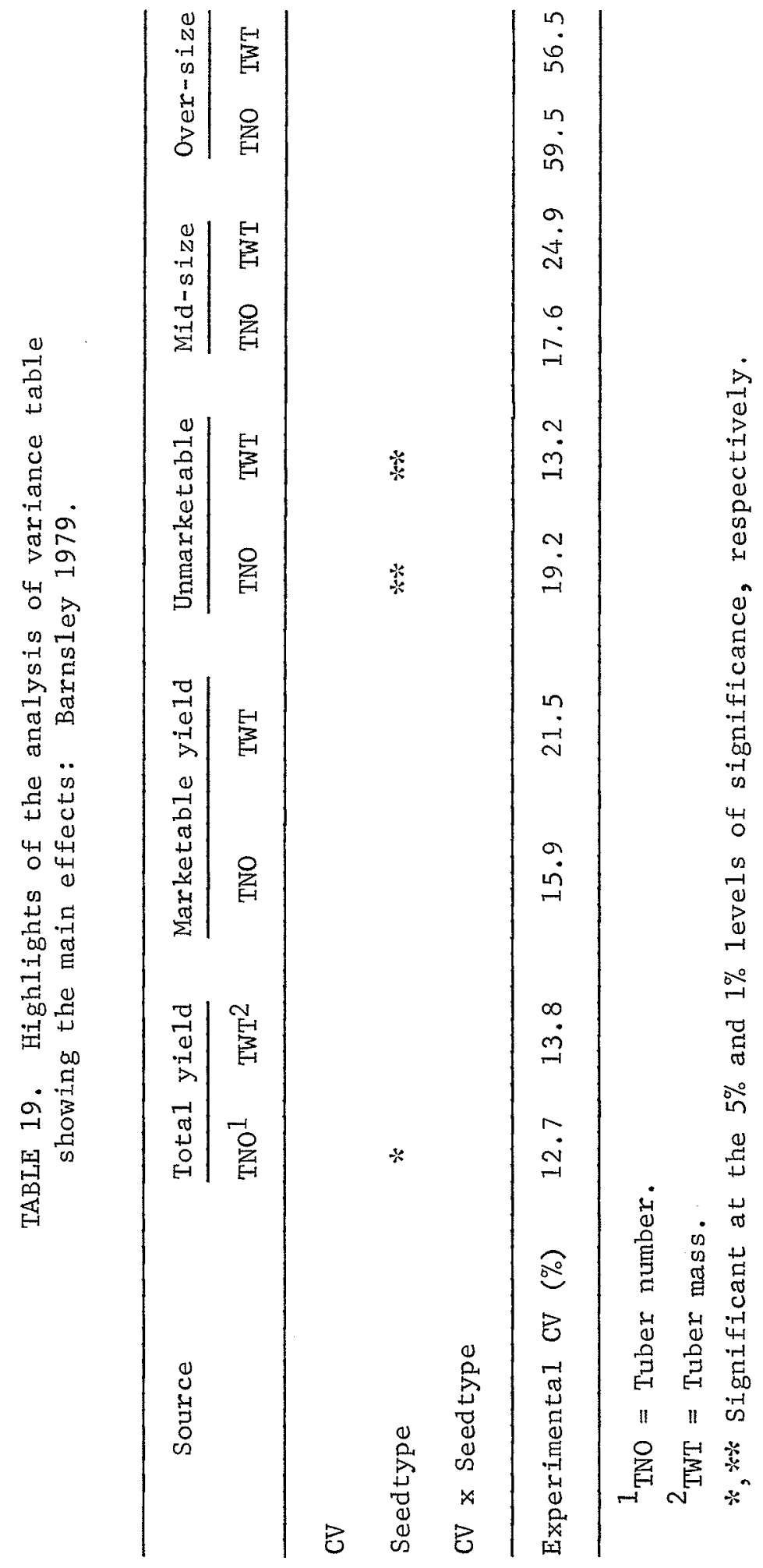




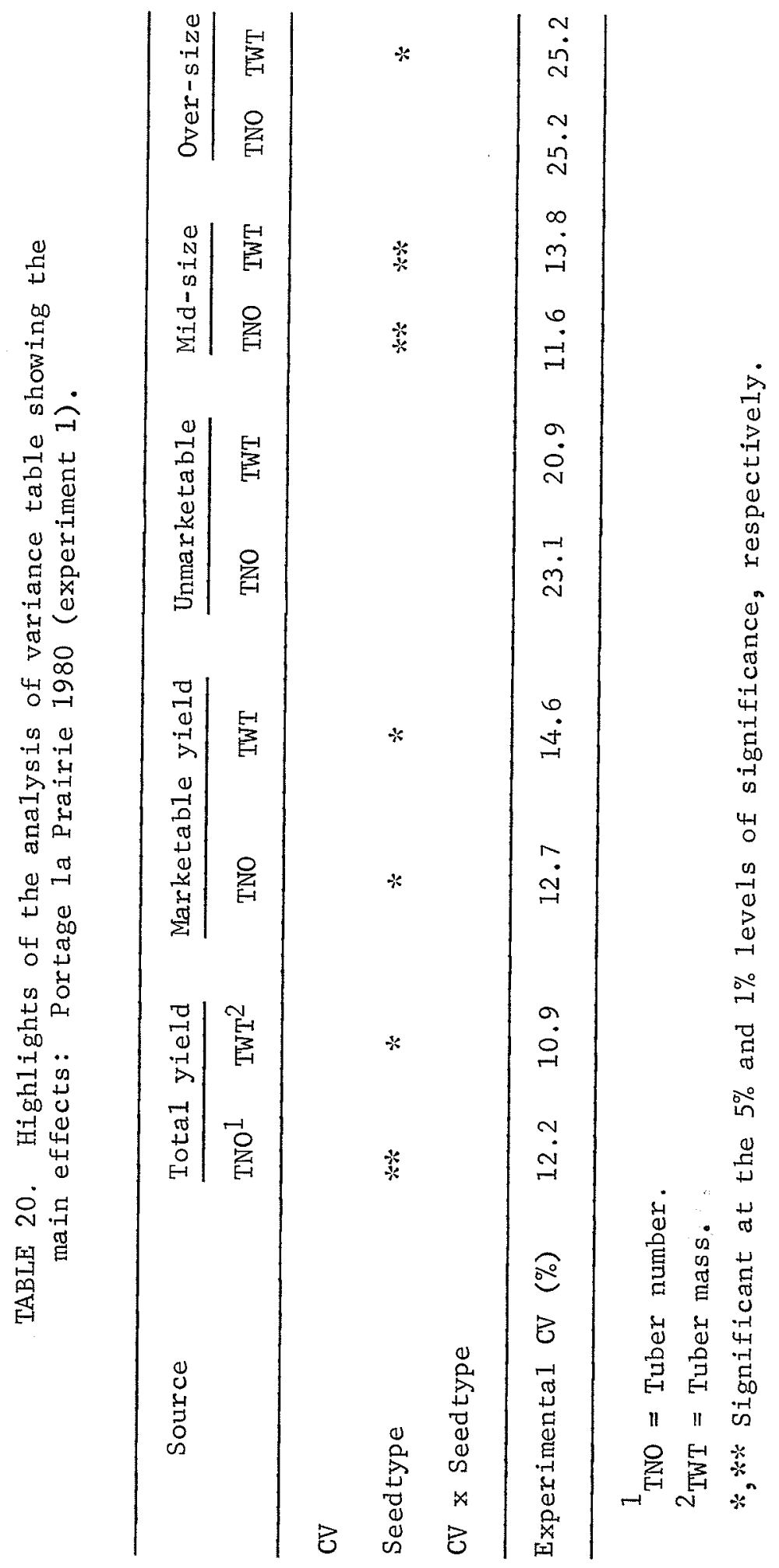




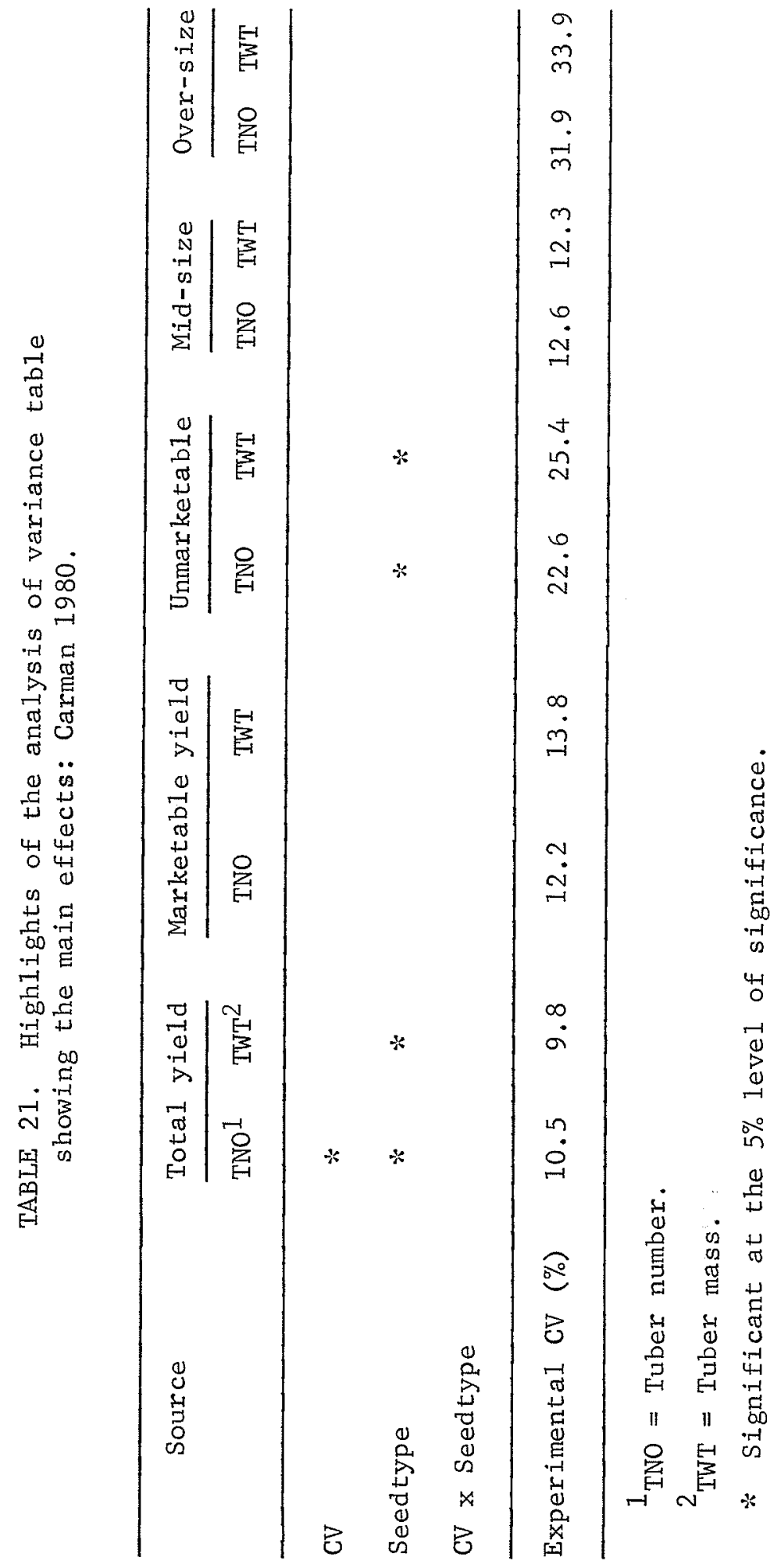




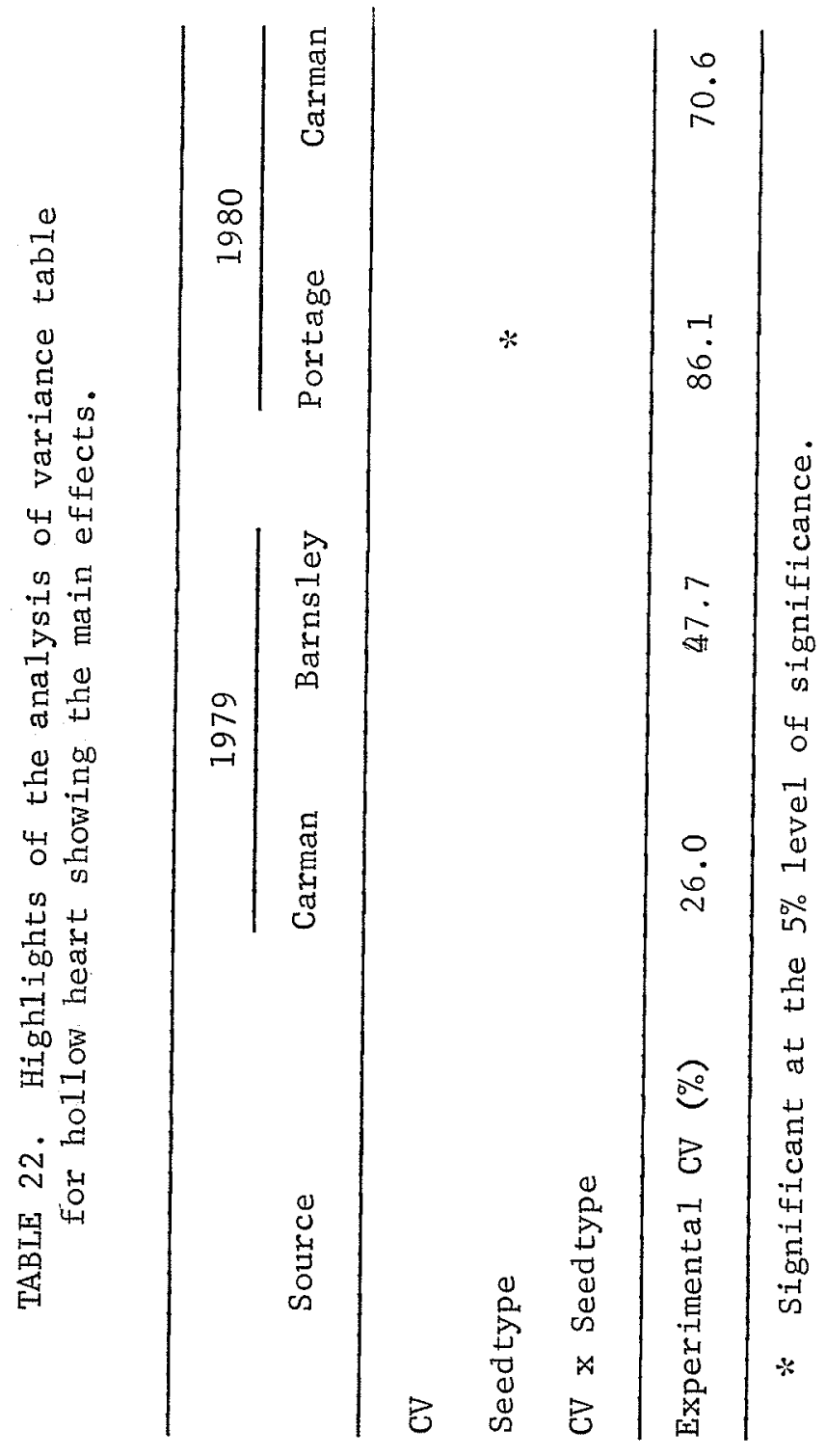




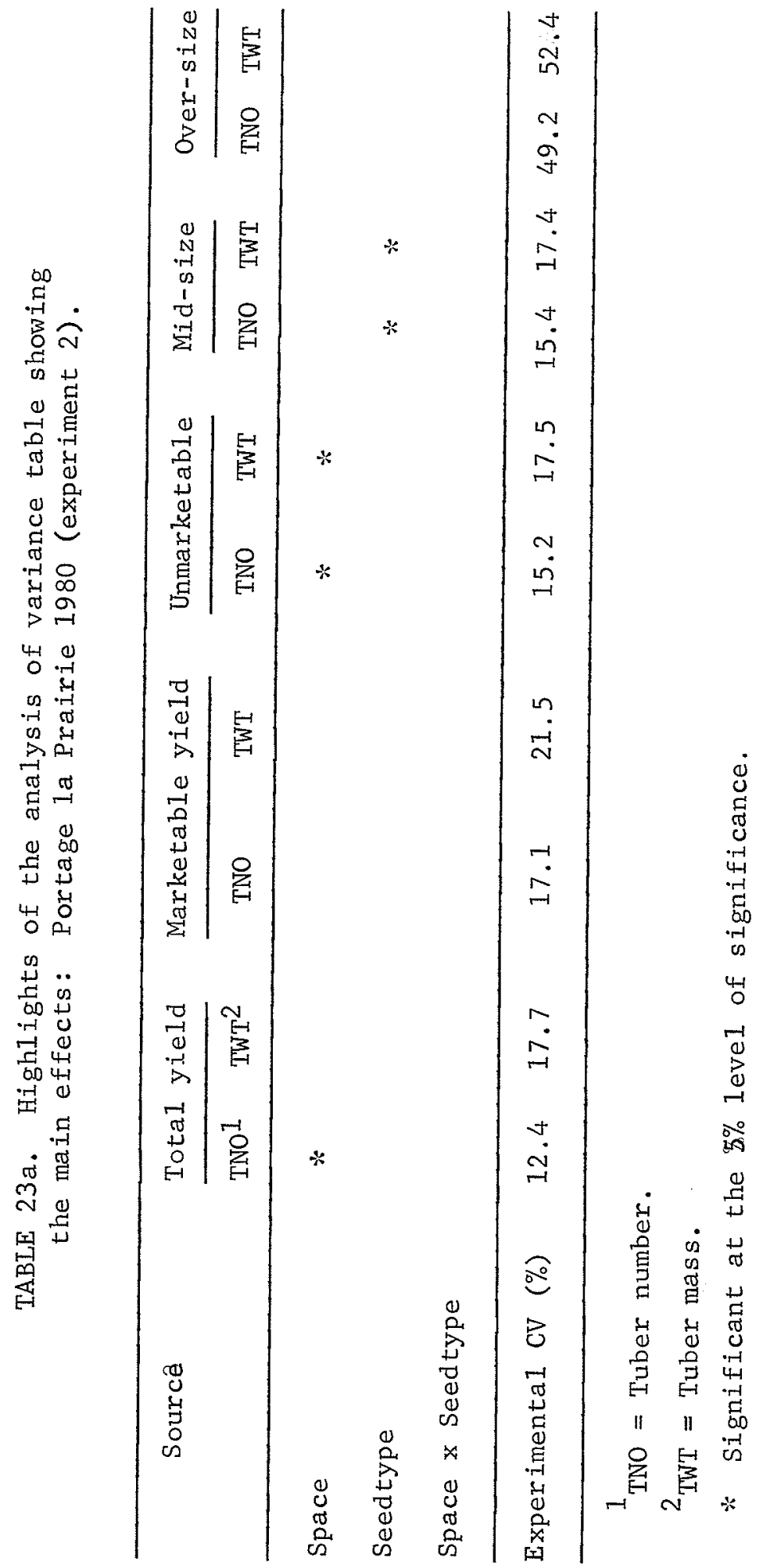




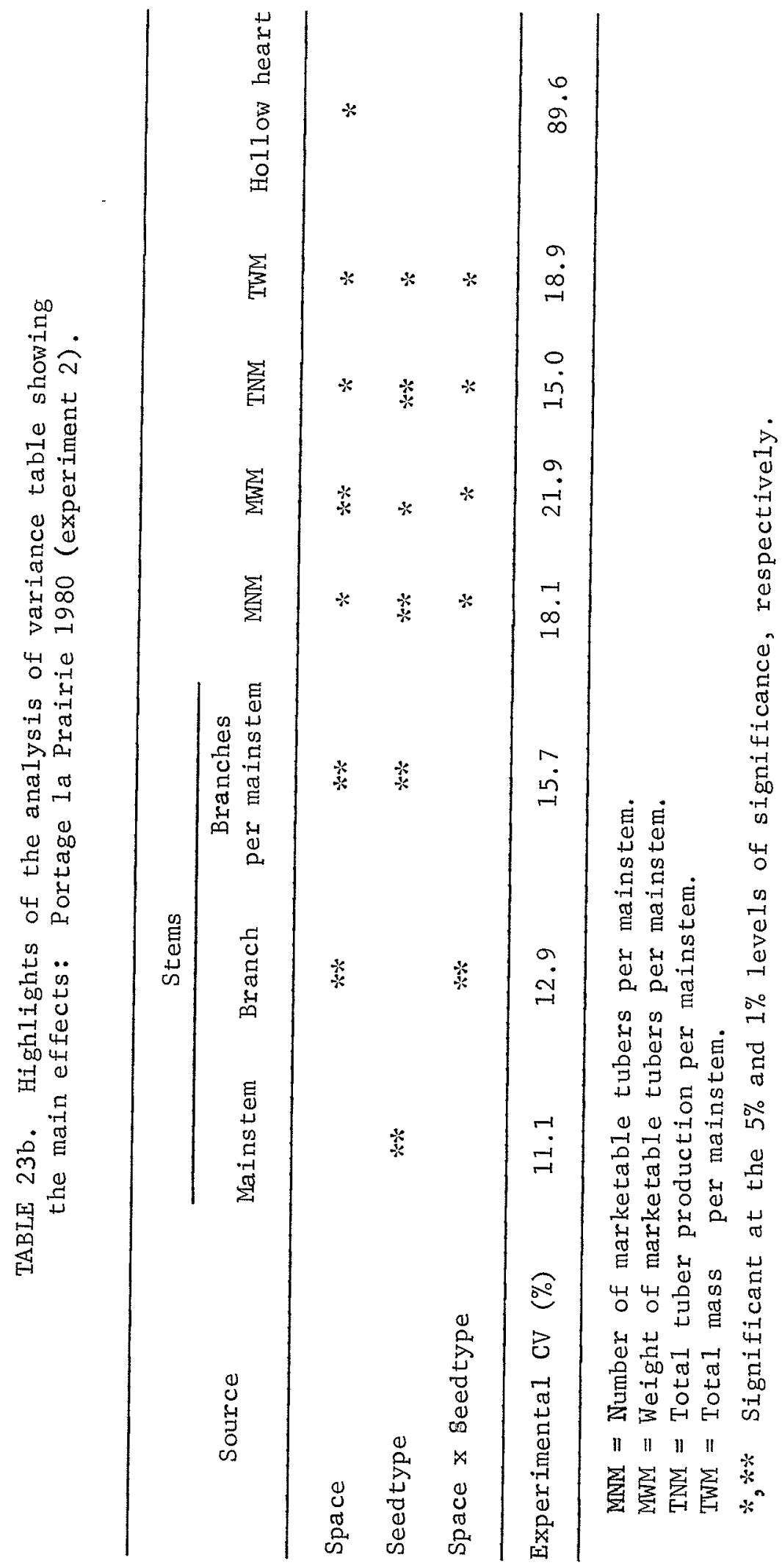

